\title{
Actinide Chemistry Research Supporting the Waste Isolation Pilot Plant (WIPP): FY94 Results
}

\author{
C.F. Novak, Editor \\ Dept. 6119, Chemical Processes Department \\ Sandia National Laboratories \\ Albuquerque, NM 87185
}

\begin{abstract}
This document contains six reports on actinide chemistry research supporting the Waste Isolation Pilot Plant (WIPP). These reports, completed in FY94, are relevant to the estimation of the potential dissolved actinide concentrations in WIPP brines under repository breach scenarios. Estimates of potential dissolved actinide concentrations are necessary for WIPP performance assessment calculations. The specific topics covered within this document are: the complexation of oxalate with Th(IV) and U(VI); the stability of Pu(VI) in one WIPP-specific brine environment both with and without carbonate present; the solubility of Nd(III) in a WIPP Salado brine surrogate as a function of hydrogen ion concentration; the steady-state dissolved plutonium concentrations in a synthetic WIPP Culebra brine surrogate; the development of a model for $\mathrm{Nd}$ (III) solubility and speciation in dilute to concentrated sodium carbonate and sodium bicarbonate solutions; and the development of a model for $\mathrm{Np}(\mathrm{V})$ solubility and speciation in dilute to concentrated sodium perchlorate, sodium carbonate, and sodium chloride media.
\end{abstract}

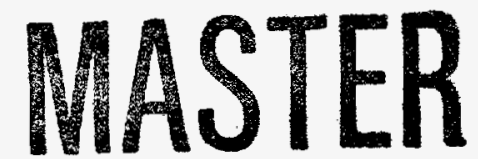


This page intentionally left blank. 


\section{DISCLAIMER}

This report was prepared as an account of work sponsored by an agency of the United States Government. Neither the United States Government nor any agency thereof, nor any of their employees, make any warranty, express or implied, or assumes any legal liability or responsibility for the accuracy, completeness, or usefulness of any information, apparatus, product, or process disclosed, or represents that its use would not infringe privately owned rights. Reference herein to any specific commercial product, process, or service by trade name, trademark, manufacturer, or otherwise does not necessarily constitute or imply its endorsement, recommendation, or favoring by the United States Government or any agency thereof. The views and opinions of authors expressed herein do not necessarily state or reflect those of the United States Government or any agency thereof. 


\section{DISCLAIMER}

Portions of this document may be illegible in electronic image products. Images are produced from the best available original document. 


\section{PREFACE}

This report presents actinide chemistry research completed in fiscal year 1994 (FY94) in support of the Waste Isolation Pilot Plant (WIPP). This work provides information funded by the Actinide Source Term Program (ASTP) and the Gas Generation Program (GGP) that is relevant to estimation of the dissolved actinide concentrations that could be present in WIPP brines under repository breach scenarios.

FY94 was a transition year for actinide chemistry research for the WIPP. The research was refocused toward determining actinide-bearing solid phases, and the variation of dissolved concentrations in equilibrium with these solubility-controlling phases, as a function of background electrolyte concentrations. This information is interpreted with a thermodynamic formalism and the Pitzer activity coefficient model, which is valid to the high ionic strengths of WIPP brines. FY94 results represent a mix of the older and newer approaches to obtaining information necessary for estimating mobile dissolved actinide concentrations for the WIPP.

This document contains six reports:

- H.N. Erten, A.K. Mohammed, and G.R. Choppin, "Variation of Stability Constants of Thorium and Uranium Oxalate Complexes with Ionic Strength," SAND93-7112C;

- D.T. Reed, S. Okajima, and M.K. Richmann, "Stability of Plutonium(VI) in Selected WIPP Brines," SAND93-7114C,

- F.I. Khalili, V. Symeopoulos, J.-F. Chen, and G.R. Choppin, "Stability of Nd in Brine," SAND93-7113C;

- $\quad$ H. Nitsche, K. Roberts, R. Xi, T. Prussin, K. Becraft, I. Al Mahamid Al Rifai, H.B. Silber, S.A. Carpenter, R.C. Gatti, and C.F. Novak, "Long Term Plutonium Solubility and Speciation Studies in a Synthetic Brine," SAND93$3846 \mathrm{C}$;

- L. Rao, D. Rai, A.R. Felmy, and R.W. Fulton, "Solubility of $\mathrm{NaNd}\left(\mathrm{CO}_{3}\right)_{2} \bullet 6 \mathrm{H}_{2} \mathrm{O}$ in Concentrated Sodium Carbonate and Sodium Bicarbonate Solutions, " SAND94$1948 \mathrm{~J}$; and

- C.F. Novak and K.E. Roberts, "Thermodynamic Modeling of Neptunium(V) Solubility in $\mathrm{Na}-\mathrm{CO}_{3}-\mathrm{HCO}_{3}-\mathrm{Cl}-\mathrm{ClO}_{4}-\mathrm{H}-\mathrm{OH}-\mathrm{H}_{2} \mathrm{O}$ Electrolytes, " SAND94-0805C. 
The first four papers (Erten et al., Reed et al., Khalili et al., Nitsche et al.) were presented at the Fourth International Conference on the Chemistry and Migration Behavior of Actinides and Fission Products in the Geosphere, "Migration '93," held in Charleston, South Carolina on 1217 December 1993, and will be published in the Proceedings. The fifth paper (Rao et al.) has been accepted by the journal Radiochimica Acta for publication. The sixth paper (Novak and Roberts) was presented at the XVIII International Symposium on the Scientific Basis for Nuclear Waste Management, held in Kyoto, Japan, on 23-27 October 1994, and will be published in the Proceedings. Articles may appear in slightly different form in these publications.

Erten et al. measured the complexation of oxalate with thorium(IV) and with uranium(VI). Oxalate is one of the organic ligand constituents of transuranic waste intended to be stored in WIPP. Organic ligands hold the potential to increase actinide dissolved concentrations by forming aqueous complexes, and this work examined this phenomenon.

Reed et al. presents information on the stability of $\mathrm{Pu}(\mathrm{VI})$ in a brine environment both with and without carbonate present. These experiments were designed for gas generation studies, so the plutonium chemistry information that can be inferred from them is limited. However, this work demonstrates some of the $\mathrm{Pu}(\mathrm{VI})$ concentrations that can be maintained in WIPP brines, particularly the stabilizing role of the carbonate anion.

Khalili et al. documents measurements of the solubility of Nd(III), a chemical analog for Am(III) and Pu(III), in a WIPP Salado brine surrogate as a function of hydrogen ion concentration. Excess Nd(III) was added and allowed to precipitate while holding the hydrogen ion concentration constant. The steady-state dissolved concentrations were measured and the solid phase was characterized for each set of chemical conditions. The $\mathrm{Nd}$ (III) solid phases found in these experiments served to guide current study of the dissolved concentrations of + III actinides.

Nitsche et al. presents measurements of dissolved plutonium concentrations in a synthetic Culebra brine called H-17 Brine. Plutonium was added in five different forms, $\mathrm{Pu}$ (III), $\mathrm{Pu}$ (IV), $\mathrm{Pu}(\mathrm{V}), \mathrm{Pu}(\mathrm{VI})$, and $\mathrm{Pu}(\mathrm{IV})$-polymer, and allowed to react in the brine for about 700 days. The 
plutonium oxidation state was not controlled, although the hydrogen ion concentration was controlled and a constant $\mathrm{CO}_{2}(\mathrm{~g})$ partial pressure was maintained. This work provides information on time scales required to reach steady-state, the steady-state oxidation state distribution of $\mathrm{Pu}$ in an oxic brine environment, the plutonium-bearing solid phases that formed, and the dissolved plutonium concentration under one set of chemical conditions.

Rao et al. determined the $\mathrm{Nd}(\mathrm{III})$ solid phases that control the neodymium solubility in sodium carbonate and sodium bicarbonate solutions. They developed a thermodynamic model using the Pitzer activity coefficient formalism to describe these data. This paper represents the type of research that is currently being performed to develop dissolved concentration models for actinides in WIPP brines. The thermodynamic parameters contained in this paper were based on available data. Additional data from experiments in progress may lead to refinement of the parameter values to describe chemical systems with greater composition ranges.

Novak and Roberts performed an extensive review of the literature to gather the existing data for the solubility and speciation of $\mathrm{Np}(\mathrm{V})$ in $\mathrm{NaClO}_{4} / \mathrm{Na}_{2} \mathrm{CO}_{3} / \mathrm{NaCl}$ solutions. Literature data was augmented with additional experiments, and a consistent dissolved concentration model was developed from this information. This model was compared with data for the solubility of $\mathrm{Np}(\mathrm{V})$ in two WIPP Culebra brines under one set of conditions. This work represents the type of assessment that is being performed for each of the actinides important to WIPP, in conjunction with laboratory work.

C.F. Novak, November 1994 
This page intentionally left blank. 


\section{CONTENTS}

VARIATION OF STABILITY CONSTANTS OF THORIUM AND URANIUM OXALATE COMPLEXES WITH IONIC STRENGTH, by H.N. Erten, A.K. Mohammed, and G.R.

Choppin.

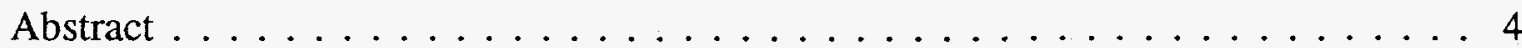

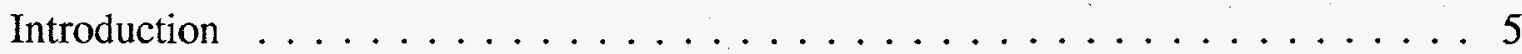

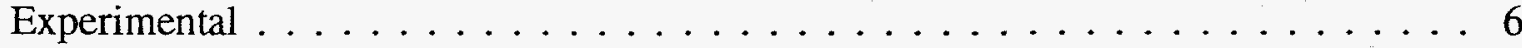

Reagents and Solutions ................. 6

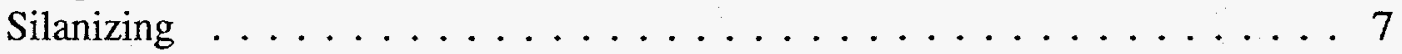

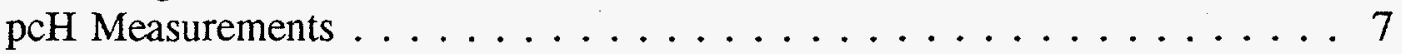

Radioactive Tracer . . . . . . . . . . . . . . . . . 8

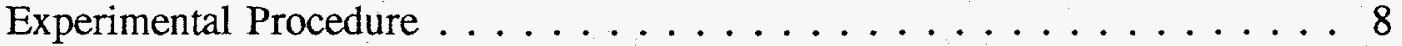

Determination of the Dissociation Constants of Oxalic Acid . . . . 8

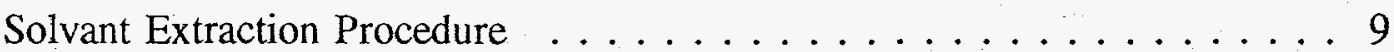

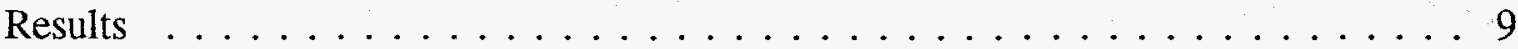

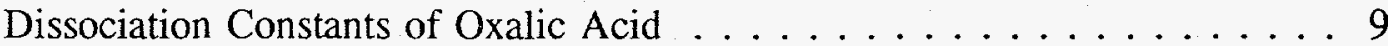

The Thorium Oxalate Complexes .................... . . 9

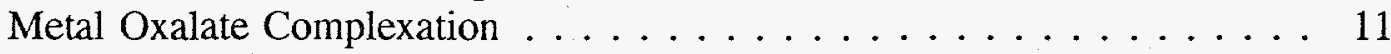

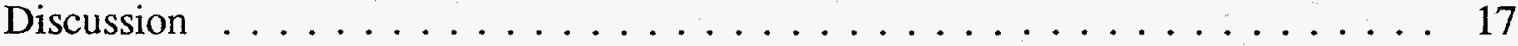

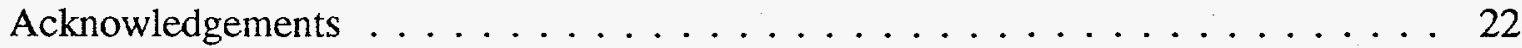

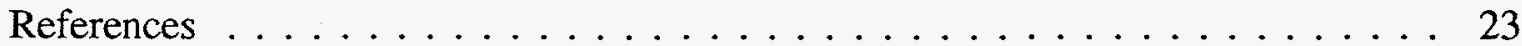

Figure 1. The variation of $1 / D$ for $T h(I V)$ as a function of total oxalate concentration at an ionic strength of $5 \mathrm{M} \mathrm{NaClO}_{4} \ldots \ldots \ldots \ldots 12$

Figure 2. Variation of the apparent stability constant, $\beta_{1}^{\text {app }}$, for thorium plus oxalate complexes as a function of hydrogen ion concentration at $1 \mathrm{M}$ ionic strength ....................... 16

Figure 3. The "extended" SIT treatment of the $\beta_{101}$ values for $\mathrm{Th}+\mathrm{Ox}$ as a function of the ionic strength (in molality) .............. 20

Table I. Dissociation Constants of Oxalic Acid at Different Ionic Strengths

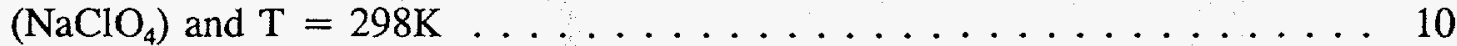

Table II. Apparent Stability Constants of the $\mathrm{Th}+\mathrm{Ox}$ Complexes $(\mathrm{T}=298 \mathrm{~K})$

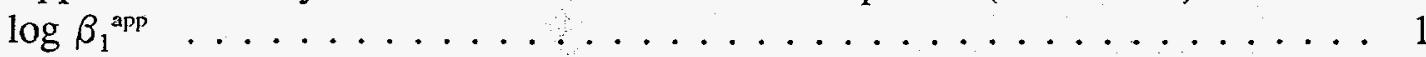

Table III. Apparent Stability Constants of the $\mathrm{Th}+\mathrm{Ox}$ Complexes $(\mathrm{T}=298 \mathrm{~K})$ $\log \beta_{2}$ app

Table IV. Apparent Stability Constants of the $\mathrm{UO}_{2}{ }^{2+}+$ Ox Complexes $(\mathrm{T}=$ $298 \mathrm{~K}) \log \beta_{1}^{\text {app }}$ and $\left(\log \beta_{2}^{\text {app }}\right)$

Table V. (a) Stability Constants of the Th+Ox Complexes (b) Stability Constants of $\mathrm{UO}_{2}{ }^{2+}+\mathrm{Ox}$ Complexes

Table VI. Results of the Extended SIT Analysis

STABILITY OF PLUTONIUM(VI) IN SELECTED WIPP BRINES by D.T. Reed, S. Okajima, and M.K. Richmann 


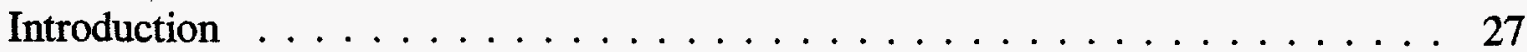

Experimental . . . . . . . . . . . . . . . . . . . 28

Results and Discussion .................... 33

Stability of $\mathrm{Pu}(\mathrm{VI})$ in Brine $\mathrm{A} \ldots \ldots \ldots \ldots \ldots \ldots \ldots$

Stability of $\mathrm{Pu}(\mathrm{VI})$ in ERDA-6 Brine $\ldots \ldots \ldots \ldots \ldots \ldots \ldots \ldots$

Stability of $\mathrm{Pu}(\mathrm{VI})$ in $\mathrm{DH}-36$ Brine $\ldots \ldots \ldots \ldots \ldots \ldots . \ldots . \ldots . \ldots$

Stability of $\mathrm{Pu}(\mathrm{VI})$ in G-Seep Brine . . . . . . . . . . . . . . 40

Discussion and Summary of Observations . . . . . . . . . . . . 42

Acknowledgement . . . . . . . . . . . . . . . . . . 43

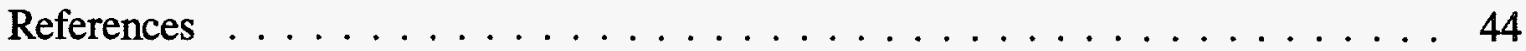

Figure 1. Absorption spectra of Pu(VI) species relevant to WIPP brine . . . . . . . . 29

Figure 2. Absorption spectra of $3 \times 10^{-4} \mathrm{M} \mathrm{Pu}$ (VI) in WIPP brine A at (a) 0 , (b)

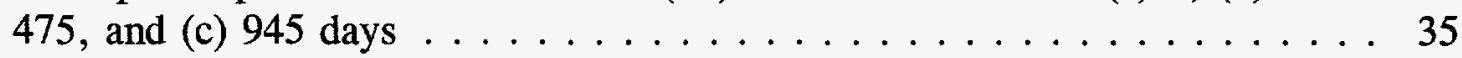

Figure 3. Absorption spectra of $1.1 \times 10^{-4} \mathrm{M}$ Pu(VI) in ERDA-6 brine at (a) 6, and

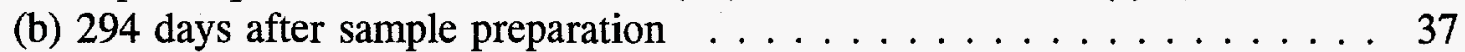

Figure 4. Absorption spectra of $\sim 10^{-4} \mathrm{M} \mathrm{Pu}(\mathrm{VI})$ in $\mathrm{DH}-36$ brine at (a) time $=0$

(b) after $2 \mathrm{hrs}$, and (c) at 3 days after sample preparation . . . . . . . 39

Figure 5. Absorption spectra of $1.1 \times 10^{-4} \mathrm{M} \mathrm{Pu}(\mathrm{VI})$ in G-Seep brine at (a) 6, (b) 77 , and (c) 280 days after sample preparation

Table 1. Composition of the WIPP Brines used in the Pu(VI) Stability Studies . . . . 30

Table 2. Summary of Stability Experiments and Related Counting Data . . . . . . . 32

SOLUBILITY OF Nd IN BRINE by F.I. Khalili, V. Symeopoulos, J.-F. Chen, and G.R. Choppin. . . . . . . . . . . . . . . . . . . . . . . . . . 47

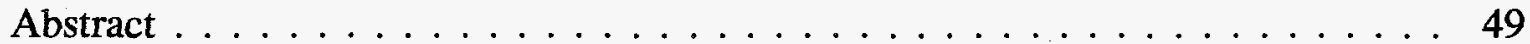

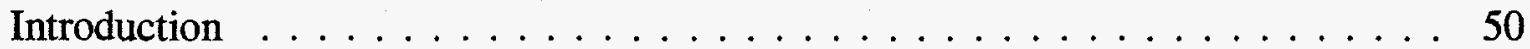

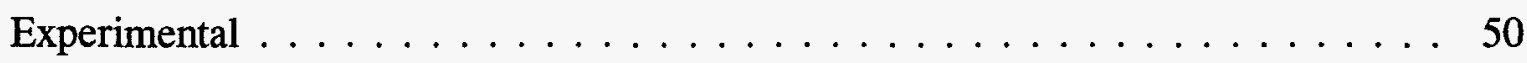

Reagents and Solutions $\ldots \ldots \ldots \ldots \ldots \ldots \ldots$

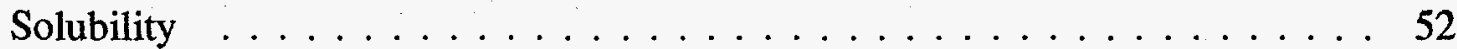

Measurement of $\mathrm{pcH} \ldots \ldots \ldots \ldots \ldots \ldots \ldots \ldots \ldots$

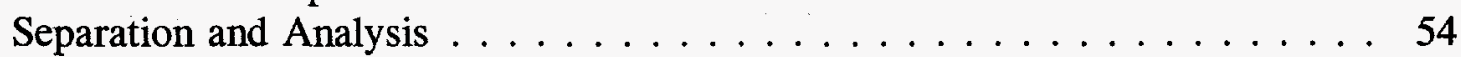

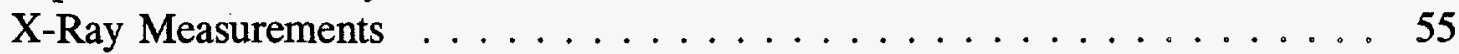

Results and Discussion . . . . . . . . . . . . . . . . . . . 55

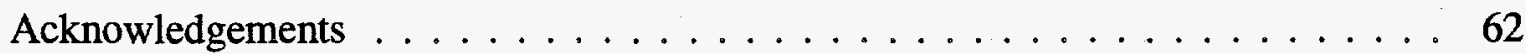

References . . . . . . . . . . . . . . . . . . . 63

Figure 1. Plot of the total concentration in solution as a function of time . . . . . . 57

Figure 2. Variation of the calculated concentrations of the major Nd(III) soluble species as a function of $\mathrm{pcH}$ compared to measured solubility . . . . . . . 60

Figure 3. Calculated concentrations of hydrolytic and carbonato species of $\mathrm{Nd}(\mathrm{III})$ as a function of $\mathrm{pcH}$ and $[\mathrm{Nd}]_{\mathrm{T}}=10^{-3} \mathrm{M} \ldots \ldots \ldots \ldots \ldots \ldots \ldots \ldots$

Table 1. Components of Synthetic Brine . . . . . . . . . . . . . 51

Table 2. Solubility of $\mathrm{Nd}^{3+}$ in Brine . . . . . . . . . . . . 56 
LONG TERM PLUTONIUM SOLUBILITY AND SPECIATION STUDIES IN A SYNTHETIC BRINE by H. Nitsche, K. Roberts, R. Xi, T. Prussin, K. Becraft, I. Al Mahamid Al Rifai, H.B. Silber, S.A. Carpenter, R.C. Gatti, and C.F. Novak. . . 65

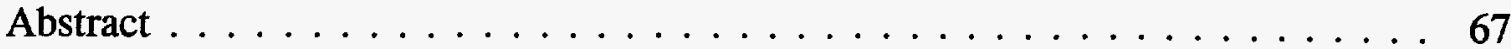

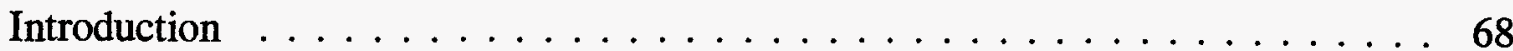

Experimental . . . . . . . . . . . . . . . . . . . . . . . . . . . 69

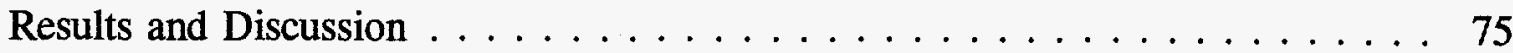

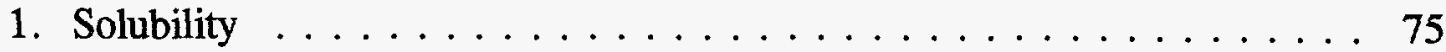

2. Oxidation State Determinations . . . . . . . . . . . 78

3. Identification and Characterization of Solids $\ldots \ldots \ldots \ldots \ldots \ldots$

Conclusions . . . . . . . . . . . . . . . . . . . . . . 84

Acknowledgements $\ldots \ldots \ldots \ldots \ldots \ldots \ldots \ldots \ldots \ldots \ldots \ldots \ldots$

References . . . . . . . . . . . . . . . . . . . . . 86

Figure 1. The operational $\mathrm{pH}$ measured by glass electrode in $\mathrm{H}-17$ Brine during saturation with a gas mixture of $2634 \pm 91 \mathrm{ppm} \mathrm{CO}_{2}, 20.75 \pm 0.88$ percent $\mathrm{O}_{2}$, with the balance made up of $\mathrm{Ar} \ldots \ldots \ldots \ldots \ldots \ldots$

Figure 2. Results of filtration experiments with Centricon-30 filters . . . . . . . 74

Figure 3. Total dissolved plutonium concentrations versus time for five initial forms of aqueous plutonium in $\mathrm{H}-17$ Brine $\ldots \ldots \ldots \ldots \ldots \ldots 77$

Figure 4. Plutonium oxidation state distributions in five different $\mathrm{H}-17$ Brine experiments at steady-state conditions $\ldots \ldots \ldots \ldots \ldots \ldots$

Table 1. Composition of $\mathrm{H}-17$ Brine . . . . . . . . . . . . . . . . . 70

Table 2. Steady-State Solution $\mathrm{pH}$ Values, Plutonium Concentrations, and Eh Values in $\mathrm{H}-17$ Brine at $25^{\circ} \mathrm{C} . \ldots \ldots \ldots \ldots \ldots$

Table 3. Methods Used for Determining Plutonium Oxidation States in H-17 Brine . . . . . . . . . . . . . . . . . . . . . . . 76

Table 4. X-Ray Powder Diffraction Patterns for the Unwashed Solids Obtained in the Plutonium $/ \mathrm{H}-17$ Oversaturation Experiments . . . . . . . . 82

SOLUBILITY OF NaNd $\left(\mathrm{CO}_{3}\right)_{2} \bullet 6 \mathrm{H}_{2} \mathrm{O}$ (c) IN CONCENTRATED SODIUM CARBONATE AND SODIUM BICARBONATE SOLUTIONS by L. Rao, D. Rai, A.r. Felmy, and R.W. Fulton . . . . . . . . . . . . . . . . . . . . . . . . . . 89

Abstract . . . . . . . . . . . . . . . . . . . . 91

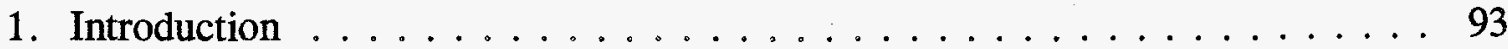

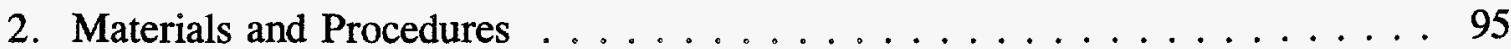

2.1 Stock Solutions and Reagents $\ldots \ldots \ldots \ldots \ldots \ldots \ldots$

2.2 Characterization of $\mathrm{Nd}_{2}\left(\mathrm{CO}_{3}\right)_{3} \bullet \mathrm{xH}_{2} \mathrm{O}(\mathrm{s}) \ldots \ldots \ldots \ldots \ldots$

2.3 Preparation and Characterization of $\mathrm{NaNd}\left(\mathrm{CO}_{3}\right)_{2} \bullet 6 \mathrm{H}_{2} \mathrm{O}(\mathrm{c}) \ldots \ldots . .96$

2.4 Solubility Experiments . . . . . . . . . . . . . . . 96

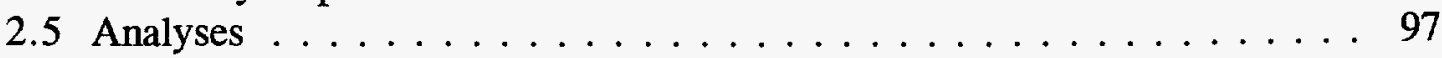


3. Results and Discussion . . . . . . . . . . . . . . . . . 98

3.1 Thermodynamic Analysis and the Solubility Product of

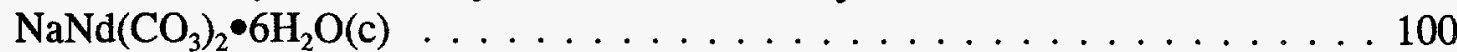

3.2 Application of the Present Model in Less Concentrated Carbonate

and Bicarbonate Systems . . . . . . . . . . . . . . . . . . . . . . 109

3.3 Solution Speciation and Stable Solid Phases . . . . . . . . . . . 111

4. Summary . . . . . . . . . . . . . . . . . . . . . . . . . 112

Acknowledgements . . . . . . . . . . . . . . . . . . . . 114

References . . . . . . . . . . . . . . . . . . . . . . . . . 115

Figure 1. Measured neodymium concentrations as functions of equilibration time and concentrations of sodium carbonate or sodium bicarbonate . . . . . . . 99

Figure 2. Solubility of $\mathrm{NaNd}\left(\mathrm{CO}_{3}\right)_{2} \bullet 6 \mathrm{H}_{2} \mathrm{O}$ (c) in sodium carbonate and sodium bicarbonate solutions . . . . . . . . . . . . . . . . . 108

Figure 3. Comparison of the predictions for the $\mathrm{Na}^{+}-\mathrm{Am}^{3+}-\mathrm{HCO}_{3}^{-}-\mathrm{CO}_{3}^{2-}-\mathrm{OH}^{-}-\mathrm{H}_{2} \mathrm{O}$ system by the previous and the present models . . . . . . . . . 110

Figure 4. Phase transition between $\mathrm{NaM}\left(\mathrm{CO}_{3}\right)_{2} \bullet 6 \mathrm{H}_{2} \mathrm{O}(\mathrm{c})$ and $\mathrm{MOH}\left(\mathrm{CO}_{3}\right)(\mathrm{c}) \ldots \ldots 113$

Table 1. Chemical Species and their $U^{\circ} / R T$ Values Used in this Study . . . . . . . . 103

Table 2. Pitzer Ion-Interaction Parameters Used in This Study . . . . . . . . . . . . . . 104

Table 3. Additional Ion-Interaction Parameters Developed in This Study . . . . . . . . 107

THERMODYNAMIC MODELING OF NEPTUNIUM(V) SOLUBILITY IN

CONCENTRATED NA-CO ${ }_{3}-\mathrm{HCO}_{3}-\mathrm{CL}-\mathrm{CLO}_{4}-\mathrm{H}-\mathrm{OH}-\mathrm{H}_{2} \mathrm{O}$ SYSTEMS by C.F. Novak

and K.E. Roberts . . . . . . . . . . . . . . . . . . . . . . . . . . . . . . . . . . 119

Abstract . . . . . . . . . . . . . . . . . . . . . . . 121

The Pitzer Activity Coefficient Model _ . . . . . . . . . . . . . . 121

Developing and Testing the $\mathrm{Np}(\mathrm{V})$ Solubility Model . . . . . . . . . . . . 121

Neptunyl Interactions with Perchlorate and Chloride (Data Series P1, P2;

T1, T2) . . . . . . . . . . . . . . . . . . . . 122

Neptunyl Hydroxide Solids and Neptunyl Hydrolysis (Data Series P3; T3) . 122

Standard Chemical Potentials for $\mathrm{NaNpO}_{2} \mathrm{CO}_{3}(\mathrm{~s}), \mathrm{NpO}_{2} \mathrm{CO}_{3}^{-}$, and

$\mathrm{NpO}_{2}\left(\mathrm{CO}_{3}\right)_{2}^{3-}$ and Ion Interactions for $\mathrm{Na}+-\mathrm{NpO}_{2} \mathrm{CO}-3$ and $\mathrm{NpO}_{2}\left(\mathrm{CO}_{3}\right)_{2}^{3-}$;

(Data Series P4, P5; T5, T6)

Standard Chemical Potential for $\mathrm{NpO}_{2}\left(\mathrm{CO}_{3}\right)_{3}^{5-}$ and $\mathrm{Na}^{+}-\mathrm{NpO}_{2}\left(\mathrm{CO}_{3}\right)_{3}^{5-}$ Ion

Interactions (Data Series P6; T7) . . . . . . . . . . 127

Discussion of Model and Parameters . . . . . . . . . . . . . . 128

Testing the Predictive Ability of the Model . . . . . . . . . . . . 128

Concluding Remarks . . . . . . . . . . . . . . . . . . . . . . . . . 129

Appendix . . . . . . . . . . . . . . . . . . . . . 130

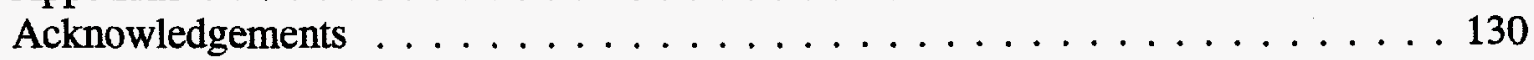

References . . . . . . . . . . . . . . . . . . . . . . . . 131 
Figure 1. Solvent extraction data of $\mathrm{Np}(\mathrm{V})$ with $\mathrm{NaDNNS} \ldots \ldots \ldots . . \ldots 122$

Figure 2. Data used to calculate standard chemical potentials for neptunium, hydroxide solid and hydrolysis species . . . . . . . . . . . . 125

Figure 3. Experimental data and model predictions of $\mathrm{NpO}_{2} \mathrm{OH}(\mathrm{am})$ solubility in $\mathrm{NaCl}$ solutions . . . . . . . . . . . . . . . . . . 126

Figure 4. Data for parameterizing/testing the model for neptunyl-carbonate reactions . . . . . . . . . . . . . . . . . . . 127

Figure 5. Comparison of model with data for extraction of neptunyl carbonate complexes . . . . . . . . . . . . . . . . . . . . . 127

Figure 6. Data and model fit of $\mathrm{NaNpO}_{2} \mathrm{CO}_{3}$ (s) solubility in $\mathrm{Na}_{2} \mathrm{CO}_{3}$ solutions . . . . 128

Figure 7. Comparison of model with $\mathrm{NaNpO}_{2} \mathrm{CO}_{3}$ (s) solubility data in $5 \mathrm{M} \mathrm{NaCl} \ldots . .129$

Table I. Experimental Systems Used to Parameterize (P) and Test (T) the Np(V)

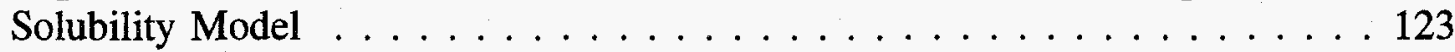

Table II. Fixed Parameters for Model Fitting . . . . . . . . . . . . . . . . . . . . . 124

Table III. Standard Chemical Potentials for Neptunyl Species Calculated in this Paper . . . . . . . . . . . . . . . . . . . . . . . 124

Table IV. Pitzer Parameters Calculated in this Paper . . . . . . . . . . . . . . . 124 
This page intentionally left blank. 


\section{Variation of Stability Constants of Thorium and Uranium Oxalate Complexes with lonic Strength}


This page intentionally left blank. 


\section{VARIATION OF STABILITY CONSTANTS \\ OF THORIUM AND URANIUM OXALATE \\ COMPLEXES WITH IONIC STRENGTH}

H.N.Erten", A.R.Mohamed ${ }^{\mathrm{b}}$ and G.R.Choppin

Department of Chemistry

Florida State Oniversity

Tallahassee, Florida 32306-3006

2 On leave of absence from Bilkent University, 06533 Bilkent, Ankara, Turkey.

b Present address Department of Chemistry, North Carolina A\&T State University, Greensboro, North Carolina 27411, OSA 


\section{ABSTRACT}

The extraction of Th(IV) and $\mathrm{UO}_{2}^{2+}$ by a solution of TTA and HDEHP, respectively in toluene has been used to obtain stability constants of their oxalate complexes at $298 \mathrm{~K}$ in 1, 3, 5, 7 and 9 $M$ ionic strength $\left(\mathrm{NaClO}_{4}\right)$ solutions. The complexes formed were the MOx, $M H O x, M_{2}$ and $M(H O x)_{2}\left(M=T h, U_{2}\right)$ species. The values were analyzed by the Specific Interaction Theory and agreed to I $\leq 3 \mathrm{M}$ but required an additional term for fitting at I / $3 \mathrm{M}$. 


\section{INTRODUCTION}

The use of nuclear energy requires an ability to dispose safely of the resulting nuclear wastes. The solution chemistry of the actinides in connection with nuclear fuel reprocessing cycles as well as with their behavior in the environment associated with geological repositories is of major interest presently. The hydrolysis of actinide cations in natural waters can limit their solubility, lead to precipitation or sorption, and reduce complexation by other ligands in the waters. For modeling requirements, stability constant values are necessary for the ligands of interest in natural waters as well as hydrolysis constants. Normal titration techniques to determine such constants require relatively high metal ion concentrations which may be prevented by hydrolysis. Furthermore, such concentrations can lead to radiolysis which can complicate the measurements and perturb the results. These difficulties can be avoided by using solvent extraction techniques with tracer concentrations of the metal ions $[1-4]$.

In this study, the stability constants of thorium and uranium oxalate complexes were measured over a range of ionic strengths.

The distribution coefficient, $D$, is defined for the extraction system as :

$$
\mathrm{D}=\Sigma[\mathrm{M}]_{\mathrm{o}} / \Sigma[\mathrm{M}]_{\mathrm{a}}
$$

Assuming only a single organic phase species, $M A_{n}$, and the various species in the aqueous phase, equation (1) can be expressed by:

$$
D=\left[M A_{n}\right]_{0} /\left([M]_{a}+[M L]_{a}+[M H L]_{a}+\left[M L_{2}\right]_{a}+\left[M(H L)_{2}\right]_{2}+\ldots\right.
$$


where $L$ is a complexing anion in the aqueous phase. This equation can be written, with the conventional symbols for stability constants, [5] as,

$$
D=\left[\mathrm{MA}_{n}\right]_{0} /[\mathrm{M}]_{2}\left(1+\left(\beta_{101}+\beta_{111}[\mathrm{H}]\right)[\mathrm{L}]+\left(\beta_{102}+\beta_{122}[\mathrm{H}]^{2}\right)[L]^{2}+\ldots\right)
$$

We define "apparent" stability constants as:

$$
\begin{aligned}
& \beta_{1}^{\text {app }} \equiv \beta_{101}+\beta_{111}[\mathrm{H}] \\
& \beta_{2}^{\text {app }} \equiv \beta_{102}+\beta_{122}[\mathrm{H}]^{2}
\end{aligned}
$$

The constant in the absence of complexation is:

$$
D_{0} \equiv\left[\mathrm{MA}_{n}\right]_{0} /[\mathrm{M}]_{\alpha}
$$

This allows restating equation (3) as:

$$
D_{0} / D=1+\beta_{1}^{\text {apP }}[L]+\beta_{2}^{\text {apP }}[L]^{2}+\ldots \ldots
$$

A plot of $\beta_{1}^{\text {app }}$ vs. [H] should give a straight line with an intercept equal to $\beta_{101}$ and a slope of $\beta_{112}$ while a plot of $\beta_{2}^{\text {app }}$ vs. [H] ${ }^{2}$ should be linear with an intercept of $\beta_{102}$ and a slope of $\beta_{122}$.

\section{EXPERIMENTAL}

\section{Reagents and Solutions}

All reagents were analytical grade. A stock solution of $0.0010 \mathrm{M}$ sodium oxalate (Aldrich) was prepared. Thenoyltrifluroacetone, TTA, was purified by sublimation. A $0.01 \mathrm{M}$ stock solution of TTA in toluene was stored in the dark. Di-(2-ethylhexyl) phosphoric acid, HDEHP, (Pfaltz and Bauer Co.) was purified by precipitation as $\mathrm{Cu}(\mathrm{DEHP})_{2}$ using the procedure of McDowell et al.[6] The purified HDEHP was dissolved in toluene and standardized with standard $\mathrm{NaOH}$ solution. Sodium perchlorate (anhydrous, Mallinckrodt) was used for ionic strength adjustment without further purification. 
${ }^{230} \mathrm{Th}$ tracer (from Oak Ridge National Laboratory) was prepared in a solution of $\mathrm{pH} 2\left(\mathrm{HClO}_{4}\right)$ such that $10 \mu \mathrm{L}$ contained $\mathrm{Ca} .4 .5 \mathrm{x}$ $10^{4} \mathrm{cpm} .{ }^{233} \mathrm{U}$ tracer (Oak Ridge National Laboratory) was evaporated to dryness and dissolved in a pH $3\left(\mathrm{HCLO}_{4}\right)$ solution such that $10 \mu \mathrm{L}$ of the solution had a count rate of $3.5 \times 10^{\circ} \mathrm{cpm}$. These count rates were obtained with the same efficiency as for the samples from the solvent extraction measurements. All solutions used in the experiments were filtered with a $0.45 \mu \mathrm{m}$ microfiltration system. Contamination from airborne particles was reduced by performing the experimental manipulations in a laminar flow hood (Environmental Air Control, Inc.)

Silanizing

To minimize the sorption of the uranyl and thorium radiotracers on extraction vials, the latter were silanized according to the process in reference [3]. The $20 \mathrm{~mL}$ standard borosilicate scintillation vials were washed with $1 \mathrm{M}$ NaOH, soaked in $3 \mathrm{M} \mathrm{HCl}$, rinsed and dried at $100^{\circ} \mathrm{C}$. The precleaned vials and their caps were silanized by shaking for $4-6$ hours in a solution containing 5\% trimethylchlorosilane and 5\% hexamethyldisilazane in toluene. The vials were dried overnight at $120^{\circ} \mathrm{C}$.

\section{pch Measurements}

A research pH meter (Accumet 950, Fischer Scientific) was used with a combination glass electrode. The $\mathrm{KCl}$ solution in the salt bridge was replaced with $\mathrm{NaCl}$ solution, as the low solubility of $\mathrm{KClO}_{4}$ at high ionic strengths causes erratic readings. The electrode was calibrated with $4.01 \pm 0.01$ and $7.00 \pm 0.01 \mathrm{pH}$ buffer 
standards. The $\mathrm{pH}$ readings were converted to hydrogen ion concentration (pcH) using calibration curves obtained by a series of $\mathrm{HClO}$, dilutions in 1 to $9 \mathrm{M} \mathrm{NaClO}$, solutions.

\section{Radioactive Tracer}

The radioactive tracers used were checked for radioactive purity by alpha and gamma ray spectrometry. The alpha radioactivity in aliquots from the experiments was counted on a Packard Instrument Tri-Carb 4000 (Hewlett Packard Instruments) liquid scintillation counter using an emulsion scintillation cocktail (Ecolume, ICN Biomedicals Co.) for both aqueous and organic phases. Experimental Procedure

\section{Determination of the Dissociation Constants of Oxalic Acid}

The $\mathrm{pK}_{\mathrm{a}}$ values of oxalic acid were determined at $3,5,7$, and $9 \mathrm{M}$ ionic strengths by potentiometric $\left(\mathrm{NaClO}_{4}\right)$ titration. The titrations were carried out using $40 \mathrm{~mL}$ solutions in a $150 \mathrm{~mL}$ vessel. A water bath maintained at $25 \pm 0.2^{\circ} \mathrm{C}$ was used for circulating water in the jacket of the titration vessel. The Gran method was used for calibrating the glass electrode at each ionic strength [7, 8]. A standardized solution of $0.1 \mathrm{M} \mathrm{HClO}_{4}$ (in $\mathrm{NaClO}_{4}$ of a certain ionic strength) was titrated against a volume $v_{0}$ of $\mathrm{NaClO}_{4}$ of the same ionic strength as that of $\mathrm{HClO}_{4}$. The exact concentration of the titrant $\left(\mathrm{HClO}_{4}\right.$ in $\left.\mathrm{NaClO}_{4}\right)$ was determined by titrating a known amount of $\mathrm{Na}_{2} \mathrm{CO}_{3}$ using bromocresol green as indicator. The titration used constant amounts of titrant for each addition. The data analysis of $\mathrm{pK}_{\mathrm{a}}$ determination was done by using the Fortran program HNEITMQ [9]. 
Solvent Extraction Procedure

For each extraction experiment, $5.0 \mathrm{~mL}$ of pre-equilibrated aqueous solution adjusted to the appropriate $\mathrm{pH}$ were placed in silanized vials. Aliquots of oxalate stock solution were added to each vial followed by $5 \mathrm{~mL}$ of TTA and HEDHP in toluene. The concentration of the organic extractant was adjusted according to the ionic strength and $\mathrm{pH}$ of the solutions used. After addition of $10 \mu \mathrm{L}$ of either ${ }^{230} \mathrm{Th}$ or ${ }^{233} \mathrm{U}$, the vials were shaken for 2 - 3 hours at room temperature. Kinetic measurements indicated that equilibrium was attained in these experiments in about $10 \mathrm{~min}$. (Th) and $1 \mathrm{hr} .(\mathrm{U})$. The vials were centrifuged and duplicate aliquots from both phases were taken for counting and $\mathrm{pH}$ measurement.

\section{RESULTS}

\section{Dissociation Constants of Oxalic Acid}

The experimental acid dissociation constants of oxalic acid are given in Table I. $\mathrm{pk}_{\mathrm{a}}$ values up to $3 \mathrm{M}$ ionic strength are reported in the literature [10]. The $\mathrm{pK}_{\mathrm{a} 1}$ values have somewhat larger errors than those of $\mathrm{pK}_{\mathrm{a} 2}$, reflecting the increased difficulty in determining the values for $\mathrm{pK}_{\mathrm{a} 1}$.

\section{The Thorium Oxalate Complexes}

Speciation calculations of the oxalate ligand indicate that in the pcH range of these studies the predominant species is the protonated anion $\mathrm{HOx}^{-}$. 


\section{TABLE I}

Dissociation Constants of Oxalic Acid at Different Ionic Strengths $\left(\mathrm{NaClO}_{4}\right)$ and $\mathrm{T}=298 \mathrm{~K}$.

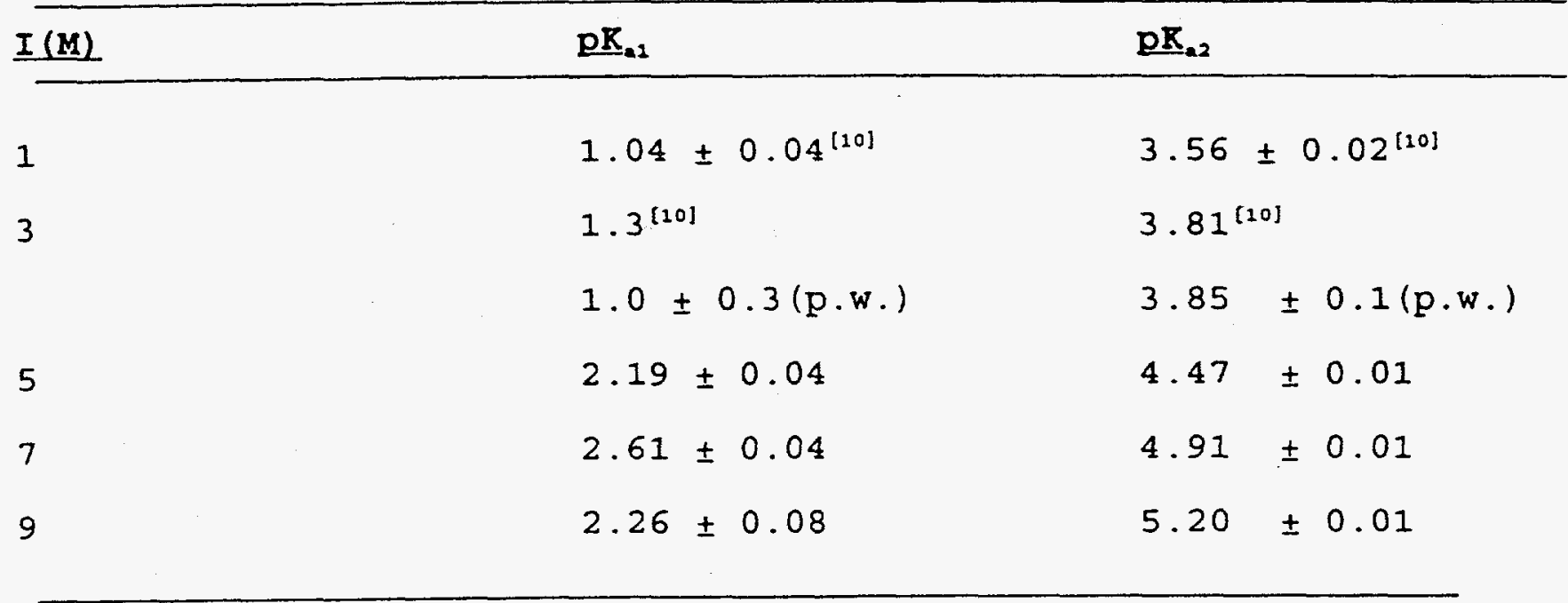




\section{Metal Oxalate Complexation}

A series of experiments covering $\mathrm{pH}^{\prime} \mathrm{s}$ from 1.5 to 4.0 were conducted at ionic strengths of $1,3,5,7$, and $9 \mathrm{M} \mathrm{NaClO}_{4}$. The concentration of oxalate anion in each vial was calculated from the measured $\mathrm{pcH}$, the total oxalate and the $\mathrm{pk}$ values of oxalic acid.

Typical curves showing the variation of $1 / D$ with oxalate anion concentration at different $\mathrm{pcH}$ values are shown in Figure 1 . The data were analyzed with Eq. 7 when nonlinear curves were obtained over higher oxalate ranges as this indicates the presence of both $1: 1$ and $1: 2$ complexes. From analysis of the curves, the apparent stability constants $\beta_{1}^{\text {app }}$ and $\beta_{2}^{\text {app }}$ were obtained as listed in Tables II, III and IV. These values represent results of at least two determinations. The relationship of these apparent stability constants to the $\beta_{101}, \beta_{111}, \beta_{102}$, and $\beta_{122}$ stability constants are given by equations (4) and (5). Figure 2 is a plot of the apparent $\beta_{1}^{\text {app }}$ as a function of hydrogen ion concentration. The intercept and slope of the linear least squares fit correspond to $\beta_{101}$ and $\beta_{111}$, respectively. This technique where by the perturbation of complexing by oxalate due to competitive hydrolysis can be used only where hydrolysis has not proceeded too far. The deviation from linearity at low $\left[\mathrm{H}^{+}\right]$in Figure 2 reflects this problem which is also observed by a poor mass balance due to sorption and/or precipitation of the neutral hydroxide. The slope at higher $\left[\mathrm{H}^{+}\right]$ values becomes unreliable due to small degree of complexation and the values at pcH 1.29 and 1.40 have not been included in Figure 2 . 


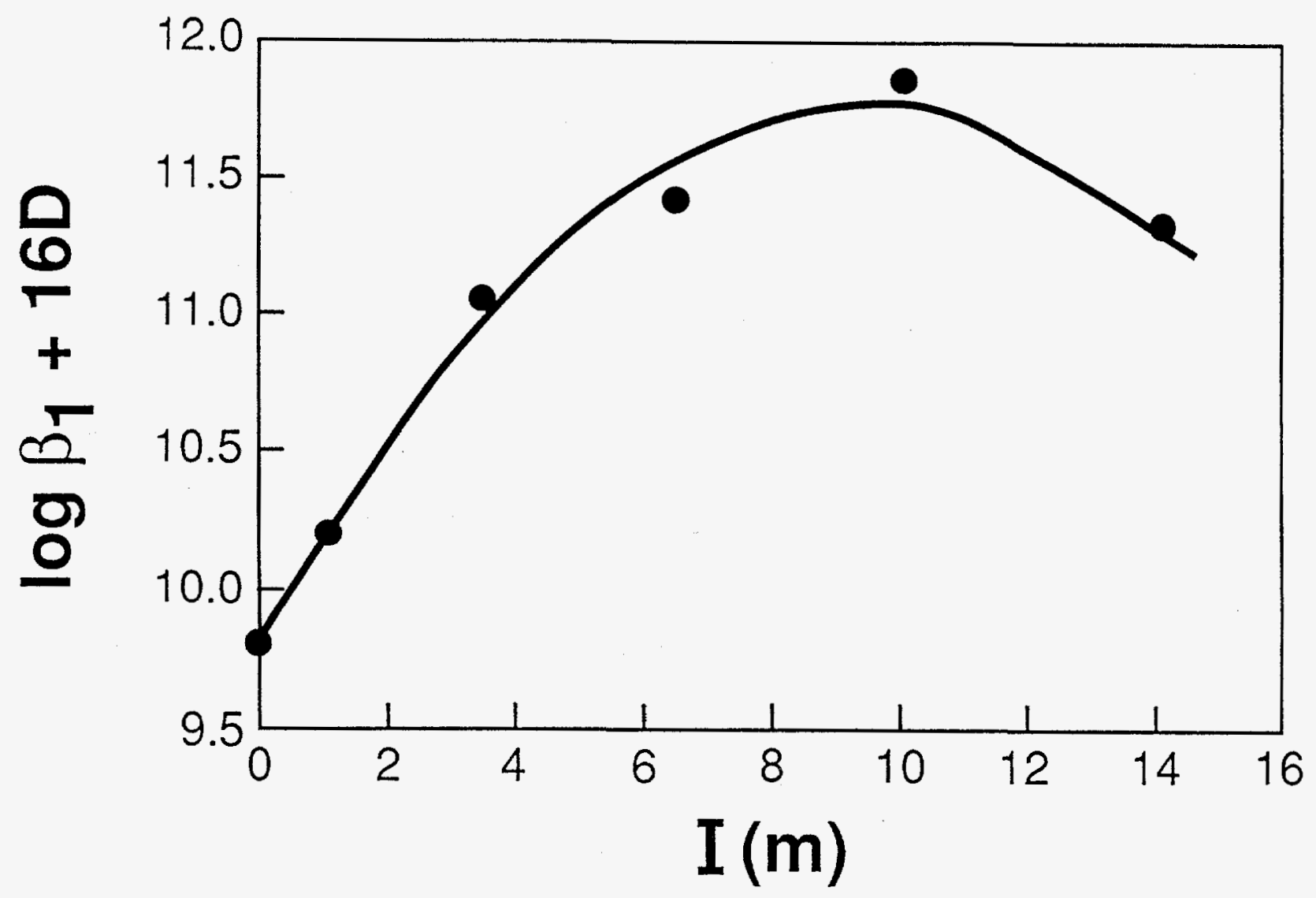

Figure 1. The variation of $1 / \mathrm{D}$ for $\mathrm{Th}(\mathrm{IV})$ as a function of total oxalate concentration at an ionic strength of $5 \mathrm{M} \mathrm{NaClO}_{4}$. 
TABLE II

Apparent stability Constants of $\underset{\mathrm{app}}{\mathrm{Th}}+\mathrm{Ox}$ Complexes $(\mathrm{T}=298 \mathrm{~K})$. $\log \beta_{1}{ }^{\text {app }}$

Ionic strength

pcH

1.29

$7.92 \pm 0.06$

$8.02 \pm 0.04$

$\underline{5 M}$

$8.96 \pm 0.02$

$7.99 \pm 0.01$

1.50

$7.88 \pm 0.02$

$7.94 \pm 0.03$

$8.68 \pm 0.02$

1.58

1.67

$7.79 \pm 0.05$

1.84

$7.70 \pm 0.02$

$7.78 \pm 0.04$

1.90

$7.62 \pm 0.03$

1.94

$7.58 \pm 0.04$

2.17

$7.37 \pm 0.01$

2.30

$7.44 \pm 0.06$

2.37

$7.19 \pm 0.04$

2.41

3.08

3.12

$6.76 \pm 0.02$

$6.78 \pm 0.05$

3.32

3.46

$6.50 \pm 0.04$

$6.47 \pm 0.01$

3.98

$6.00 \pm 0.08$

$6.09 \pm 0.17$

$8.66 \pm 0.05$

$7.68 \pm 0.07$

$7.31 \pm 0.04$

$6.76 \pm 0.04$

$6.45 \pm 0.01$

$6.29 \pm 0.07$ $\underline{7 M}$

$\underline{9 M}$

$8.92 \pm 0.02$
$8.37 \pm 0.06$

$8.99 \pm 0.05$

$8.79 \pm 0.07$

$8.40 \pm 0.07$

$8.53 \pm 0.04$

$7.23 \pm 0.09$

$7.27 \pm 0.04$

$7.18 \pm 0.04$

$7.15 \pm 0.05$

$7.08 \pm 0.01$

$6.91 \pm 0.05$

$7.14 \pm 0.05$

$6.75 \pm 0.08$

$7.06 \pm 0.10$ 
TABLE III

Apparent Stability Constants of $T h+O x$ Complexes $(T=298 \mathrm{~K})$
\[ \log \beta_{2} \text { app } \]

Ionic Strength

\section{pcH}

1M

$\underline{3 M}$

$\underline{5 M}$

$\underline{71}$

$\underline{9 M}$

1.29

$13.34 \pm 0.31$

$14.26 \pm 0.34$

$16.31 \pm 0.45$

$18.16 \pm 0.17$

$17.49 \pm 0.14$

$1.40 \quad 13.62 \pm 0.14 \quad 13.94 \pm 0.35$

$1.50 \quad 13.62 \pm 0.13$

$1.67 \quad 13.78 \pm 0.02$

$1.84 \quad 13.71 \pm 0.01$

$13.66 \pm 0.16$

$15.90 \pm 0.02$

$16.81 \pm 0.42$

$16.23 \pm 0.76$

$1.90 \quad 13.61 \pm 0.05$

$2.17 \quad 13.44 \pm 0.03$

$2.37 \quad 13.00 \pm 0.02$

$15.98 \pm 0.03$

$3.1212 .79 \pm 0.0$

$12.76 \pm 0.07$

$12.44 \pm 0.04$

$13.63 \pm 0.03$

$14.31 \pm 0.03$

$3.46 \quad 12.16 \pm 0.02$

$12.18 \pm 0.03$

$12.47 \pm 0.02$

$13.30 \pm 0.05$

$13.13 \pm 0.31$

3.98

$12.00 \pm 0.04$

$12.06 \pm 0.02$

$12.23 \pm 0.05$

$13.77 \pm 0.02$

$13.17 \pm 0.14$ 


\section{TABLE IV}

Apparent Stability Constants of the $\mathrm{UO}_{2}{ }^{2+}+$ Ox Complexes $(\mathrm{T}=298 \mathrm{~K}$ ) $\log \beta_{1}^{\text {app }}$ and $\left(\log \beta_{2}^{\text {app }}\right)$

\begin{tabular}{lc}
\hline & $\underline{3 M}$ \\
1.61 & $6.20 \pm 0.02$ \\
1.89 & $6.13 \pm 0.01$ \\
2.19 & $6.07 \pm 0.02$
\end{tabular}

2.23

Ionic Strength

$\underline{5 M} \underline{7 M}$

$\underline{9 M}$

2.27

$7.16 \pm 0.02$

2.32

$6.12 \pm 0.02$

2.49

$6.70 \pm 0.02$

2.79

$6.80 \pm 0.05$

2.84

$7.60 \pm 0.06$

3.03

$6.92 \pm 0.01$

3.07

$(12.92 \pm 0.01)$

3.11

$(14.43+0.21)$

$7.96 \pm 0.03$

3.22

$6.05 \pm 0.06$

(11.07 \pm 0.20$)$

3.34

$5.97 \pm 0.06$

3.42

(11.09 \pm 0.10$)$

3.52

$6.84 \pm 0.04$

(12.40 0.11 )

3.54

$7.04 \pm 0.06$

(13.18 \pm 0.19 ) 


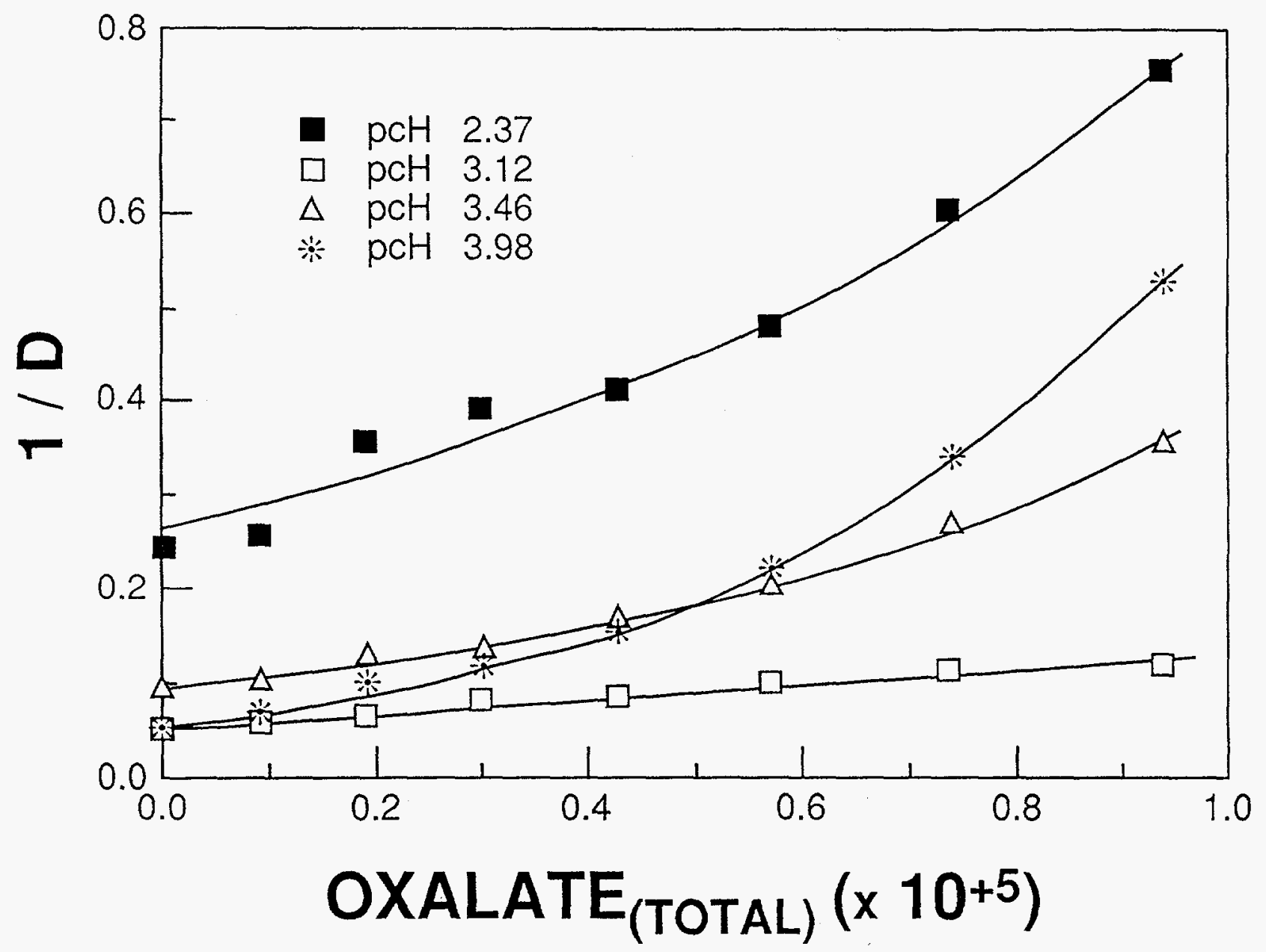

Figure 2. Variation of the apparent stability constant, $\beta_{1}^{\text {app }}$, for thorium plus oxalate complexes as a function of hydrogen ion concentration at $1 \mathrm{M}$ ionic strength 
The $\beta_{101}, \beta_{102}, \beta_{111}$, and $\beta_{122}$ values are given in Tables $V$ (a) and (b) where the errors indicated represent 10 .

\section{DISCUSSION}

The bonding of Th(IV) to inorganic and organic ligands in complexes can be described by an ionic model. As a result the number of ligands as well as their geometric arrangement about the thorium cation are determined primarily by electrostatic and steric factors. The hydrolysis of Th(IV) can be extensive even in relatively acidic solutions $(\mathrm{pH} \geq 1)$. Since most organic ligands involving carboxylate groups (e.g., oxalate) require pH values of 3 or higher in order to provide enough ionization of the 1 igand for interaction, studies of thorium complexation are limited due to hydrolytic competition. Only a single study exists in the literature of the stability constants $\beta_{101}$ and $\beta_{102}$ of thoriumoxalate complexes in perchlorate solution [11] obtained from solubility measurements. Our values are not in agreement with these data.

Uranyl ion, $\mathrm{UO}_{2}{ }^{2+}$, does not hydrolyze as readily and has been studied more extensively than thorium. Stability constants for the $\mathrm{UO}_{2}{ }^{2+}$-oxalate system are available in the literature for $4 \mathrm{M}$ ionic strength [11, 12, 13] and below. In the present work, we obtained a $\log \beta_{101}$ of $6.00 \pm 0.05$ which compares well with that reported at $4 \mathrm{M}[13]$.

The Nuclear Energy Agency has recommended [14] the use of Specific Ion Interaction Theory (SIT) in the analysis of stability 
TABLE V

(a) Stability Constants of Th+Ox Complexes

$\begin{array}{ccccc}I(M) & \underline{\log \beta_{101}} & \underline{\log \beta_{112}} & \underline{\log \beta_{102}} & \underline{\log \beta_{122}} \\ I & 6.93 \pm 0.03 & 9.47 \pm 0.01 & 13.13 \pm 0.17 & 17.01 \pm 0.04 \\ 3 & 7.06 \pm 0.09 & 9.52 \pm 0.12 & 13.16 \pm 0.05 & 16.95 \pm 0.03 \\ 5 & 7.12 \pm 0.08 & 10.24 \pm 0.05 & 13.19 \pm 0.17 & 19.29 \pm 0.01 \\ 7 & 7.37 \pm 0.04 & 10.84 \pm 0.01 & 13.76 \pm 0.06 & 20.21 \pm 0.01 \\ 9 & 6.74 \pm 0.12 & 10.63 \pm 0.01 & 13.03 \pm 0.18 & 19.79 \pm 0.01\end{array}$

(b) Stability Constants of $\mathrm{UO}_{2}{ }^{2+}+$ Ox Complexes

\begin{tabular}{|c|c|c|c|c|}
\hline$I(M)$ & $\underline{\log \beta_{101}}$ & $\underline{\log \beta_{111}}$ & $\underline{\log \beta_{102}}$ & $\underline{\log \beta_{122}}$ \\
\hline 1 & $5.99^{11}$ & & & \\
\hline 3 & $6.00 \pm 0.05$ & $7.57 \pm 0.06$ & $11.21 \pm 0.18$ & \\
\hline 5 & $6.55 \pm 0.28$ & $9.22 \pm 0.17$ & $12.28 \pm 0.11$ & $18.86 \pm 0.15$ \\
\hline 7 & $6.55 \pm 0.33$ & $10.43 \pm 0.07$ & $12.94 \pm 0.40$ & $20.04 \pm 0.42$ \\
\hline 9 & $7.37 \pm 0.05$ & $10.06 \pm 0.02$ & $14.08 \pm 0.11$ & $19.48 \pm 0.59$ \\
\hline
\end{tabular}


constants measured at different ionic strengths up to ca. $3 \mathrm{~m}$. In the SIT approach, the value of the stability constant at zero ionic strength, $\beta^{0}$, is related to the value $\beta^{I}$ at ionic strength $I$ (in molality) by:

$$
\log \beta^{I}=\log \beta^{0} \pm \Delta Z^{2} \cdot D-\Delta \epsilon \cdot I
$$

Here,

$$
\Delta Z^{2}=\left(Z_{M L}\right)^{2}-Z_{M}^{2}-Z_{L}^{2}
$$

and

$$
\begin{gathered}
D=0.509 I^{1 / 2} / 1+1.5 I^{1 / 2} \\
\Delta \epsilon=\epsilon_{M L}-\epsilon_{M}-\epsilon_{L}
\end{gathered}
$$

Where $\mathrm{Z}$ is the charge on the designated species and $\epsilon$ is an interaction coefficient for the cation and anion pair. Values of $\log \beta$ predicted by the SIT agree well with the experimental values from 0 to ca. $3 \mathrm{M}$ ionic strength. Above $\mathrm{I}=3 \mathrm{M}$ there is usually a growing difference between the experimental data and the SIT calculation.

Recently an extension of the SIT treatment has been proposed [15] to cover higher ionic strengths by including a quadratic term of the interaction, $+\Delta \delta \cdot I^{2}$, in equation (8). The results of extended SIT analysis of our data are given in Table VI which Figure 3 illustrates the extended SIT fitting of the Thox ${ }^{2+}$ complex stability constant. This extension of the S.I.T. treatment to higher ionic strengths is empirical and, generally, analyses at such ionic strengths have used the Pitzer formalism [16]. We have 


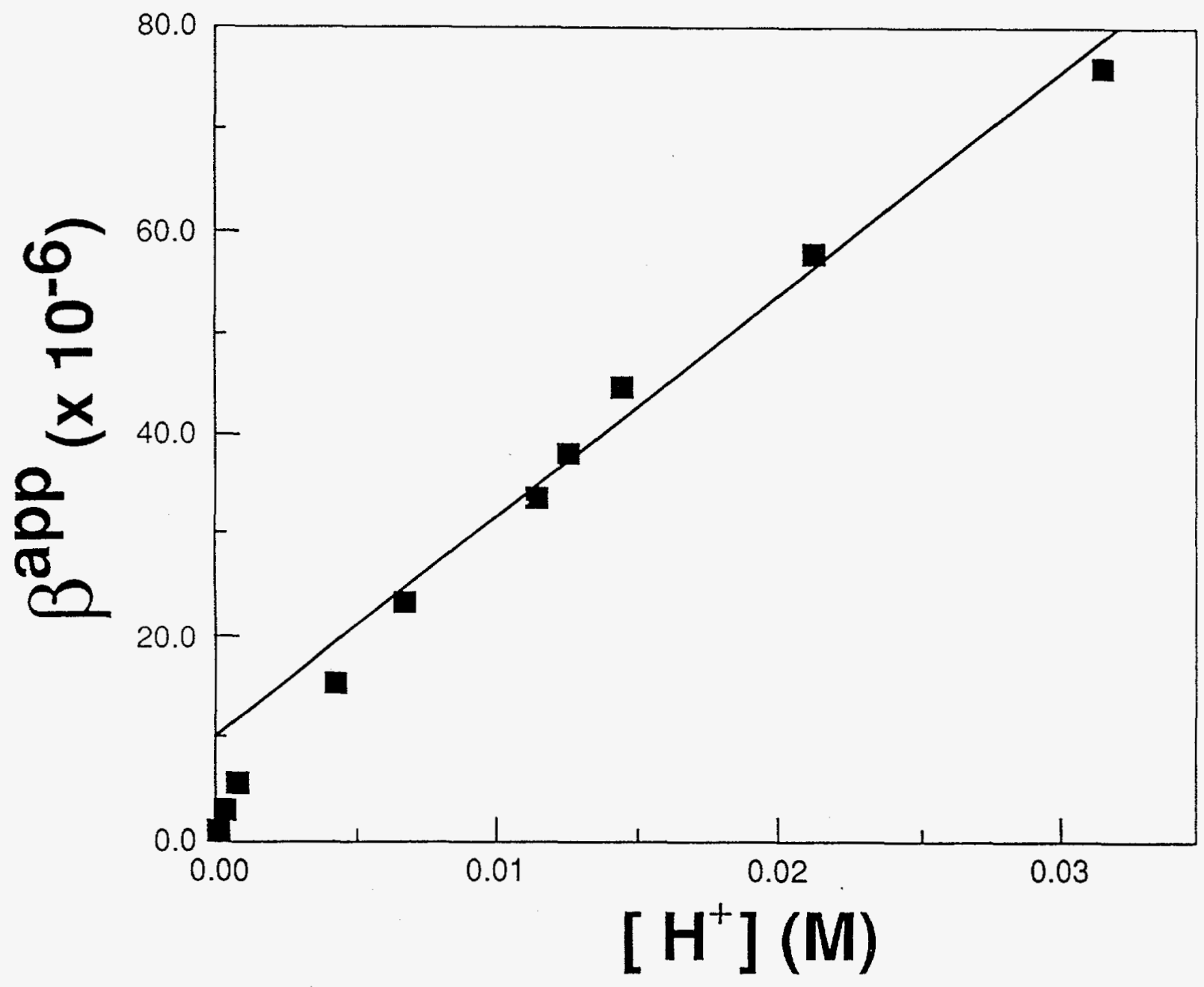

Figure 3. The "extended" SIT treatment of the $\beta_{101}$ values for Th+Ox as a function of the ionic strength (in molality) 
TABLE VI

Results of the Extended SIT Analysis

\begin{tabular}{|c|c|c|c|}
\hline Species & $\underline{\log \beta^{\circ}}$ & $\Delta \epsilon$ & $\underline{\Delta \delta}$ \\
\hline HOx- & 4.33 & 0.26 & -0.0062 \\
\hline $\mathrm{UO}_{2} \mathrm{HOx}^{+}$ & 5.60 & 1.03 & -0.044 \\
\hline $\mathrm{UO}_{2} \mathrm{OX}$ & 5.60 & 0.45 & -0.019 \\
\hline ThHOx ${ }^{3+}$ & 11.0 & 0.51 & -0.020 \\
\hline Tho $x^{2+}$ & 9.8 & 0.42 & -0.022 \\
\hline $\operatorname{Th}(\mathrm{HOX})_{2}{ }^{2+}$ & 18.13 & 1.42 & -0.061 \\
\hline ThO $\mathrm{x}_{2}$ & 17.5 & 0.56 & -0.028 \\
\hline
\end{tabular}


not used this latter approach in this study due to insufficient data to obtain the Ritzer parameters.

\section{ACKNOWLEDGMENTS}

This research, carried out through the waste Isolation Pilot PIant Project, was supported by the USDOE under Contract DE-1C0476DP0089, and by Sandia National Laboratories under Subcontract 691734 to Florida State University.

H. N. Erten acknowledges financial support from the Turkish Scientific and Technical Research Council (TUBITAK). 


\section{REFERENCES}

1. Khalili, F.I., G.R. Choppin, and E.N. Rizkalla. 1988. "The Nature of Uranium(VI) Complexation by Halates and Chloroacetates," Inorganica Chimica Acta. Vol. 143, no. 1, $131-135$.

2. Caceci, M.S., and G.R. Choppin. 1983. "The Determination of the First Hydrolysis Constant of Europium(III) and Americium(III)," Radiochimica Acta. Vol. 33, no. 2-3, 101-104.

3. Caceci, M.S., and G.R. Choppin. 1983. "The First Hydrolysis Constant of Uranium(VI)," Radiochimica Acta. Vol. 33, no. 4, 207-212.

4. Choppin, G.R., and J.N. Mathur. 1991. "Hydrolysis of Actinyl(VI) Cations," Radiochimica Acta. Vol. 52-53, pt. 1, $25-28$.

5. Sillen, L.G., and A.E. Martell. 1964. Stability Constants oc Metal-Ion Complexes. 2nd ed. Chemical society Special Publication No. 17. London: Chemical Society.

6. McDowell, W.J., P.T. Perdue, and G.N. Case. 1976. "Purification of Di (2-ethylhexyl) phosphoric Acid," Journal of Inorganic and Nuclear Chemistry. Vol. 38, no. 11, 2127-2129.

7. Gran, G. 1950. "Determination of the Equivalent Point in Potentiometric Titrations, "Acta Chemica Scandinavica. Vol. 4, pt. $1,559-577$.

8. Gran, G. 1952. "Determination of the Equivalence Point in Potentiometric Titrations. Part II," The Analyst. Vol. 77, no. $920,661-707$.

9. Torres, R.A., C.E.A. Palmer, P.S. Baisden, R.E. Russo, and R.J. Silva. 1990. "A Comparison of Photoacoustic Spectroscopy, and Potentiometry as Probes of Lanthanide Speciation," Analytical Chemistry. Vol. 62, no. 3, 298-303.

10. Smith, R.M., and A.E. Martell. 1989. Critical Stability Constants. Volume 6: Second Supplement. New York, NY: Plenum Press. p. 325.

11. Moskvin, A.I., and L.N. Essen. 1967. "The Solubility Product of Thorium oxalate and the Composition and Dissociation Constants of Oxalato-Complexes of Thorium in Aqueous Solution," Russian Journal of Inorganic Chemistry. Vol. 12, no. 3, 359-362.

12. Miyake, C., and H.W. Nuernberg. 1967. "Coordination Compounds of Actinides. I. The Determination of the Stability Constants of Uranyl Complexes with Anions of Carboxylic Acids," Journal of Inorganic and Nuclear Chemistry. Vol. 29, no. 9, 2411-2429. 
13. Havel, J. 1969. "Spectrophotometric Study of Complex Formation of Uranyl with Oxalic Acid," Collection of Czechoslovak Chemical Communications. Vol. 34, no. 11, 3248-3265.

14. Grenthe, I., J. Fuger, R.J.M. Konings, R.J. Lemire, A.B. Muller, C. Nguyen-Trung, and H. Wanner. 1992. Chemical Thermodynamics of Uranium. Eds. H. Wanner and I. Forest. Chemical Thermodynamics 1. New York, NY: North-Holland.

16. Pitzer, K.S., ed. 1991. Activity Coefficients in Electrolyte Solutions. 2nd ed. Boca Raton, FL: CRC Press. 


\section{Stability of Plutonium(VI) in Selected WIPP Brines}


This page intentionally left blank. 


\title{
Stability of Plutonium(VI) in Selected WIPP Brines \\ By D. T. Reed, S. Okajima* and M. K. Richmann
}

Chemical Technology Division, Argonne National Laboratory, 9700 South Cass Avenue, Argonne, IL. 60439. 4837

Plutonium / Waste Isolation Pilot Plant (WIPP) / Speciation / Spectroscopy

\begin{abstract}
The redox stability of plutonium (VI) in WIPP brine was investigated by monitoring the oxidation state as a function of time using a combination of absorption spectrometry, radiochemical counting and filtration. Studies were performed with Pu-239 and Pu-238 in four WIPP brines at concentrations between $10^{-3}$ and $10^{-8} \mathrm{M}$ for durations as long as two years. Two synthetic brines, Brine $\mathrm{A}$ and ERDA6, and two brines collected in the WIPP underground, DH-36 and G-Seep, were used. The stability of $\mathrm{Pu}(\mathrm{VI})$ depended on the brine composition and the speciation of the plutonium in that brine. When carbonate was present, a stable Pu(VI)-carbonate complex was observed. In the absence of carbonate, Pu(VI) hydrolytic species predominate. These species had a wide range of stability in the brines investigated. The reported results will help define the speciation of plutonium in WIPP brine and its potential for migration.
\end{abstract}

\section{Introduction}

Herein, we report the results of work that was done in support of gas generation experiments with Puspiked brines performed for the Waste Isolation Pilot Plant (WIPP) [1-4]. It is important to note that the primary objective of these experiments was to establish the stability of plutonium in solution rather than its solubility in WIPP brine. Qualitative information on the likely speciation of plutonium in the systems we studied is also reported. Both the speciation and stability data are limited and should be interpreted in the context of all the work being sponsored by the WIPP to address the issue of plutonium solubility.

${ }^{*}$ Currently resides in Woodridge Illinois 
The WIPP, located in the Salado bedded salt formation in southeastern New Mexico in the northern portion of the Delaware Basin, is being investigated as a site for final disposal of transuranic (TRU) waste $[5,6]$. The predominant actinide in TRU waste will be plutonium-239 which is present at levels of up to 10 grams per waste drum. The most likely scenarios leading to plutonium migration from the WIPP are human intrusion and brine inundation which may mobilize the plutonium as an aqueous species. The speciation and solubility of plutonium under this latter scenario, therefore, are potentially important factors in evaluating the long-term performance of the WIPP.

The key parameters that define the speciation and solubility of plutonium in WIPP brines are redox conditions, $\mathrm{pH}$, carbonate concentration, organics present, degree of aggregation, and inorganic complexation. The operational $\mathrm{pH}\left(\mathrm{pH}_{\mathrm{OP}}\right)$ of all four WIPP brines investigated was typically in the range of $\mathrm{pH}=6$ to 7 . This was measured by a Ross electrode and uncorrected for ionic strength. The actual $\mathrm{pH}$ in these systems is approximately 0.5 to $1 \mathrm{pH}$ unit higher than we measured when corrected for ionic strength $[7,8]$. In this $\mathrm{pH}$ range, $\mathrm{Pu}(\mathrm{VI})$ is readily hydrolyzed in the absence of strong complexants. Of the anions present in WIPP brines (e.g., halides, carbonate/bicarbonate, and sulfate), only the carbonate/bicarbonate species are expected to be important. The formation constants $[9,10]$ for these species are not well established in dilute systems and are less well-defined in highionic-strength media. Spectra obtained in our laboratory relevant to Pu(VI) speciation in WIPP brine are shown in Figure 1 and are consistent with those reported elsewhere [10-13].

\section{Experimental}

We established the redox stability of Pu(VI) in WIPP brine by monitoring the oxidation state as a function of time using absorption spectrometry. Studies were performed with $\sim 10^{-3}, 10^{-4}, 10^{-6}$, and $10^{-8}$ M Pu(VI) in four WIPP brines. Two of these were synthetic brines designated Brine A and ERDA-6. The other two were brines collected in the WIPP underground designated DH-36 and G-Seep. The composition of these brines is given in Table 1. 

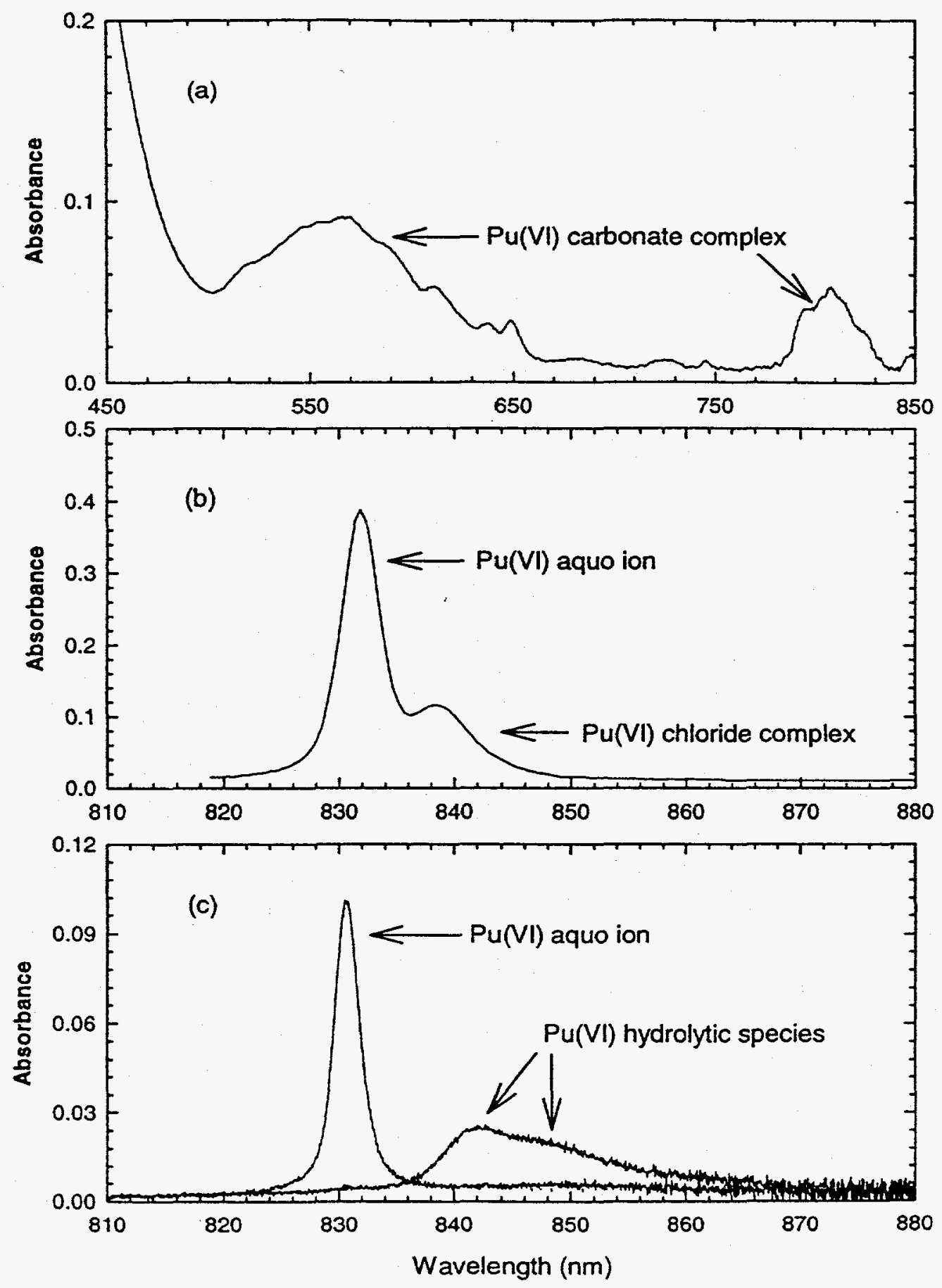

Fig. 1. Absorption spectra of Pu (VI) species relevant to WIPP brine: (a) $0.0029 \mathrm{M} \mathrm{Pu}$ (VI) in 0.01 $\mathrm{M}$ carbonate at $\mathrm{pH}_{\mathrm{OP}}=6.9$, (b) $\mathrm{Pu}$ (VI) in presence of chloride at $\mathrm{pH}_{\mathrm{OP}}=3$, (c) $2 \times 10^{-4} \mathrm{M}$ $\mathrm{Pu}(\mathrm{VI})$ aquo ion $\left(\mathrm{pH}_{\mathrm{OP}}=2.8\right)$ and hydrolytic species $\left(\mathrm{pH}_{\mathrm{OP}}=6.9\right)$ 
Table 1. Composition of the WIPP Brines used in the Pu(VI) Stability Studies

\begin{tabular}{ccccc}
\hline $\begin{array}{c}\text { Element, } \\
\text { Species, or } \\
\text { Property }\end{array}$ & ${ }^{1}$ Brine A & ${ }^{1}$ ERDA-6 & ${ }^{2}$ DH-36 & ${ }^{2} \mathrm{G}-$ Seep \\
\cline { 2 - 5 } $\mathrm{Cl}$ & 5.38 & 4.64 & 5.37 & 5.07 \\
$\mathrm{SO}_{4}{ }^{2-}$ & 0.044 & 0.167 & 0.173 & 0.297 \\
$\mathrm{~B}$ & 0.020 & 0.063 & 0.136 & 0.14 \\
$\mathrm{CO}_{3}{ }^{2-} / \mathrm{HCO}_{3}-$ & 0.0114 & 0 & $<0.00007$ & $<0.00008$ \\
$\mathrm{Br}$ & 0.0051 & 0.011 & 0.018 & 0.017 \\
$\mathrm{Na}$ & 1.83 & 4.85 & 3.67 & 4.18 \\
$\mathrm{~K}$ & 0.767 & 0.097 & 0.471 & 0.338 \\
$\mathrm{Mg}$ & 1.44 & 0.019 & 0.816 & 0.612 \\
$\mathrm{Ca}$ & 0.015 & 0.012 & 0.0096 & 0.0077 \\
${ }^{3} \mathrm{pH}$ & 6.3 & 6.2 & 5.94 & 6.14 \\
\hline
\end{tabular}

${ }^{1}$ Based on recipe provided by the WIPP

${ }^{2}$ As-received analysis of brine collected underground at the WIPP

${ }^{3}$ Obtained using a combination Ross electrode and uncorrected for ionic strength 
Plutonium-239, >99\% isotopic purity, was received from Oak Ridge National Laboratory and oxidized to the VI state in $50 \mathrm{mg}$ quantities by taking to near-dryness in perchloric acid. The Pu(VI) was dissolved in triple-distilled water and analyzed for oxidation-state purity using absorption spectrometry. We used the absorption at $622 \mathrm{~nm}$ with $\varepsilon=7.5 \mathrm{M}^{-1} \mathrm{~cm}^{-1}$ [13] to estimate the plutonium concentration and establish the dilution sequence needed to prepare a solution with the desired plutonium concentration in the WIPP brine.

The $\mathrm{pH}_{\mathrm{OP}}$ of the stock solution prepared in this way was typically about 1 . This was adjusted to a near-neutral $\mathrm{pH}_{\mathrm{OP}}$, to match the $\mathrm{pH}_{\mathrm{OP}}$ of the brine, by adding sodium hydroxide. This solution was sequentially diluted twice into the brine of interest to minimize change in the concentration of the bulk constituents of the brine. After each dilution, the solution was checked for evidence of precipitation. This twice-diluted Pu-spiked brine typically had a plutonium concentration of $\sim 10^{-3} \mathrm{M}$ and corresponds to the $2 \times 10^{-3} \mathrm{M}$ solutions identified in Table 2 . Additional brine was added to a final volume of 30 to $1000 \mathrm{~mL}$ to generate samples with lower plutonium concentrations. These solutions were equilibrated for 3-7 days before taking a sample for alpha scintillation counting. This was done with a Packard Model 2050 alpha scintillation counter by adding a small aliquot of the Puspiked brine to Ultima-Gold cocktail and comparing the results against a series of plutonium stock samples prepared in the same way from NIST-traceable plutonium standards. The scintillationcounting data were within $10 \%$ of the predicted plutonium concentration based on the dilution sequence utilized.

The two brines collected underground at the WIPP were DH-36 and G-Seep. These had been collected by Sandia National Laboratories (WIPP/SNL), stored in 1 Liter bottles, and subsequently shipped to Argonne. The twenty l-Liter bottles received for each brine were opened and combined into a single 5-Gallon (18.9 L) polyethylene jug. This jug had been pre-rinsed with high-purity water and two liters of the groundwater. Prior to use, the groundwater in the jug was stirred and coarse filtered, using a glass frit, in room air. There was no attempt to control $\mathrm{P}_{\mathrm{CO2}}$ throughout the handling. 
Table 2. Summary of Stability Experiments and Related Counting Data. Uncertainty is $\pm 10 \%$.

\begin{tabular}{|c|c|c|c|c|c|}
\hline \multirow[t]{2}{*}{$\begin{array}{l}\text { WIPP } \\
\text { Brine }\end{array}$} & \multirow[t]{2}{*}{$\begin{array}{l}\text { Experiment } \\
\text { Designation }\end{array}$} & \multirow{2}{*}{$\begin{array}{l}\text { Nominal } \\
\text { [Pu], } \\
\text { M }\end{array}$} & \multirow{2}{*}{$\begin{array}{c}\text { Experiment } \\
\text { Duration, } \\
\text { months }\end{array}$} & \multicolumn{2}{|c|}{$\begin{array}{c}{ }^{2}[\mathrm{Pu}] \\
\mathrm{M}\end{array}$} \\
\hline & & & & Initial & Final \\
\hline \multirow[t]{11}{*}{ Brine A } & Stock & 0.0023 & 12 & ND & $\mathrm{ND}$ \\
\hline & GG-B $1-41$ & $10^{-4}$ & 26 & $3.4 \times 10^{-4}$ & $\mathrm{ND}$ \\
\hline & GG-B1-42 & $10^{-4}$ & 26 & $2.8 \times 10^{-4}$ & $2.7 \times 10^{-4}$ \\
\hline & GG-B1-61 & $10^{-6}$ & 6 & $6.3 \times 10^{-7}$ & $7 \times 10^{-7}$ \\
\hline & GG-B1-62 & $10^{-6}$ & 6 & $5.4 \times 10^{-7}$ & $7 \times 10^{-7}$ \\
\hline & GG-B1-81 & $10^{-8}$ & 6 & $6.7 \times 10^{-9}$ & $6.7 \times 10^{-9}$ \\
\hline & GG-B1-82 & $10^{-8}$ & 6 & $7.1 \times 10^{-9}$ & $7.5 \times 10^{-9}$ \\
\hline & ${ }^{\mathrm{b}} \mathrm{GG}-38-61$ & $10^{-6}$ & 4.5 & $7.8 \times 10^{-7}$ & $7.7 \times 10^{-7}$ \\
\hline & ${ }^{\circ} \mathrm{GG}-38-62$ & $10^{-6}$ & 4.5 & $7.7 \times 10^{-7}$ & $7.2 \times 10^{-7}$ \\
\hline & ${ }^{b}$ GG-38-81 & $10^{-8}$ & 4.5 & $9.0 \times 10^{-9}$ & $8.5 \times 10^{-9}$ \\
\hline & ${ }^{b} \mathrm{GG}-38-82$ & $10^{-8}$ & 4.5 & $8.5 \times 10^{-9}$ & $8.1 \times 10^{-9}$ \\
\hline \multirow[t]{2}{*}{ ERDA-6 } & GG-B4-4l & $10^{-4}$ & 8 & $1.1 \times 10^{-4}$ & $0.86 \times 10^{-4}$ \\
\hline & GG-B4-42 & $10^{-4}$ & 8 & $1.9 \times 10^{-4}$ & $1.1 \times 10^{-4}$ \\
\hline \multirow[t]{3}{*}{ DH-36 } & Stock & $10^{-3}$ & 12 & 0.002 & ND \\
\hline & GG-B3-41 & $10^{-4}$ & 4 & $0.99 \times 10^{-4}$ & $0.64 \times 10^{-4}$ \\
\hline & GG-B3-42 & $10^{-4}$ & 4 & $1.4 \times 10^{-4}$ & $0.70 \times 10^{-4}$ \\
\hline \multirow[t]{3}{*}{ G-Seep } & Stock & $10^{-3}$ & 12 & 0.002 & $\mathrm{ND}$ \\
\hline & GG-B2-41 & $10^{-4}$ & 4 & $1.1 \times 10^{-4}$ & $0.44 \times 10^{-4}$ \\
\hline & GG-B2-42 & $10^{-4}$ & 4 & $1.4 \times 10^{-4}$ & $0.57 \times 10^{-4}$ \\
\hline
\end{tabular}

'by alpha scintillation counting

${ }^{b} \mathrm{Pu}$ isotope was Pu-238 introduced in the III oxidation state.

ND - not determined 
filtration, and addition of the brines to the vessels. We confirmed that the groundwaters did not initially contain significant levels of carbonate by analyzing the head space in the jug above the brine for carbon dioxide. All groundwaters were stored in sealed vessels in the dark at room temperature $\left(21 \pm 2^{\circ} \mathrm{C}\right)$.

Approximately $3 \mathrm{~mL}$ of the Pu-spiked brine was placed in a $1 \times 1-\mathrm{cm}$ gas-tight quartz cuvette for spectrometric analysis. These samples were also kept in the dark at room temperature $\left(21 \pm 2^{\circ} \mathrm{C}\right)$ and periodically analyzed to monitor changes in the absorption spectrum. Absorption spectra were obtained with either a Hitachi model 340 or a Varian CARY-5 spectrometer and recorded digitally for analysis. On the Hitachi spectrometer, visible and NIR spectra were obtained independently. This is denoted in the Figures by a dashed line. The Pu(VI) absorption in the high concentration plutonium samples $\left(10^{-3} \mathrm{M}\right)$, had an optical density greater than 0.1 . The reference for these spectra was the same brine used to make up the plutonium-containing samples in a similar cuvette. For the $-10^{-4} \mathrm{M}$ Pu-spiked brines, where the absorbance was low, both reference and sample spectrum were taken in the same cuvette to minimize cell-to-cell differences in absorbance.

\section{Results and Discussion}

The stability experiments performed are listed in Table 2. Also included are the corresponding alphascintillation counting data. We report data that were obtained over a period of up to 26 months. Some of these experiments, however, are still ongoing.

\section{Stability of Pu(VI) in Brine A}

The majority of the stability experiments were performed in Brine A which was the only brine investigated that had significant levels of carbonate in solution. Spectra and counting data were obtained when the total plutonium concentration exceeded $10^{-4} \mathrm{M}$. When the concentration was on the order of $10^{-6} \mathrm{M}$ or less, only counting data were obtained, since the absorbance was too low to detect. 
Based on the counting data, there was no significant decrease in the plutonium concentration as a function of time for all the plutonium isotopes and concentrations investigated. Filtering the solution through $0.2 \mu$ filters did not affect the total concentration measured.

Absorption spectra for the carbonate complex in Brine A are shown, as a function of time, in Figure 2. At plutonium concentrations greater than $10^{-4} \mathrm{M}$, a plutonium(VI)-carbonate complex was observed that was stable with time. This solution was also filtered through a $0.2-\mu$ filter and reanalyzed spectrometrically. No change in the spectrum was observed. There was no spectral evidence for $\mathrm{Pu}(\mathrm{V})$ or $\mathrm{Pu}(\mathrm{IV})$ carbonate species although we cannot preclude the possibility of their existence at low concentrations $(<10 \%$ of the total plutonium).

The absorption spectrum obtained in Brine $\mathrm{A}$ is most similar to that obtained for the Pu(VI) carbonate species (see Figure 1). It is characterized by a blue-shifted absorption band at $806 \mathrm{~nm}$. The apparent extinction coefficient for the species we have observed was approximately 40 $\mathrm{M}^{-1} \mathrm{~cm}^{-1}$ which is comparable to that published for the carbonate complex [11]. Some evidence of Pu (VI) hydrolytic species can be seen in the higher resolution CARY-5 spectrum (Fig. 2c). It is not surprising that a carbonate species is predominant in Brine A since this brine contains $0.011 \mathrm{M}$ sodium bicarbonate and the $\mathrm{pH}_{\mathrm{OP}}$ of the brine is greater than 7 .

Based on our data, we are proposing that the Pu(VI) species in Brine $A$ is primarily a carbonate complex. Detailed library spectra, however, do not exist that would permit a more specific species assignment. Both $\mathrm{Pu}(\mathrm{VI})$ in Brine $\mathrm{A}$ and $\mathrm{Pu}(\mathrm{VI})$ in the carbonate/bicarbonate system have a broad absorption at $570 \mathrm{~nm}$. In the $800-850 \mathrm{~nm}$ regime however, significant differences are apparent. The full-width half-height of the $806 \mathrm{~nm}$ absorption is $10 \mathrm{~nm}$ for Brine A compared with $30 \mathrm{~nm}$ in the carbonate/ bicarbonate system. In addition to this, there is greater complexity in the band structure in the bicarbonate/carbonate sample.

We believe that the best explanation for the observed stability of the $\mathrm{Pu}(\mathrm{VI})$-carbonate species is the presence of carbonate rather that radiolysis. In the absence of carbonate (see later discussions 

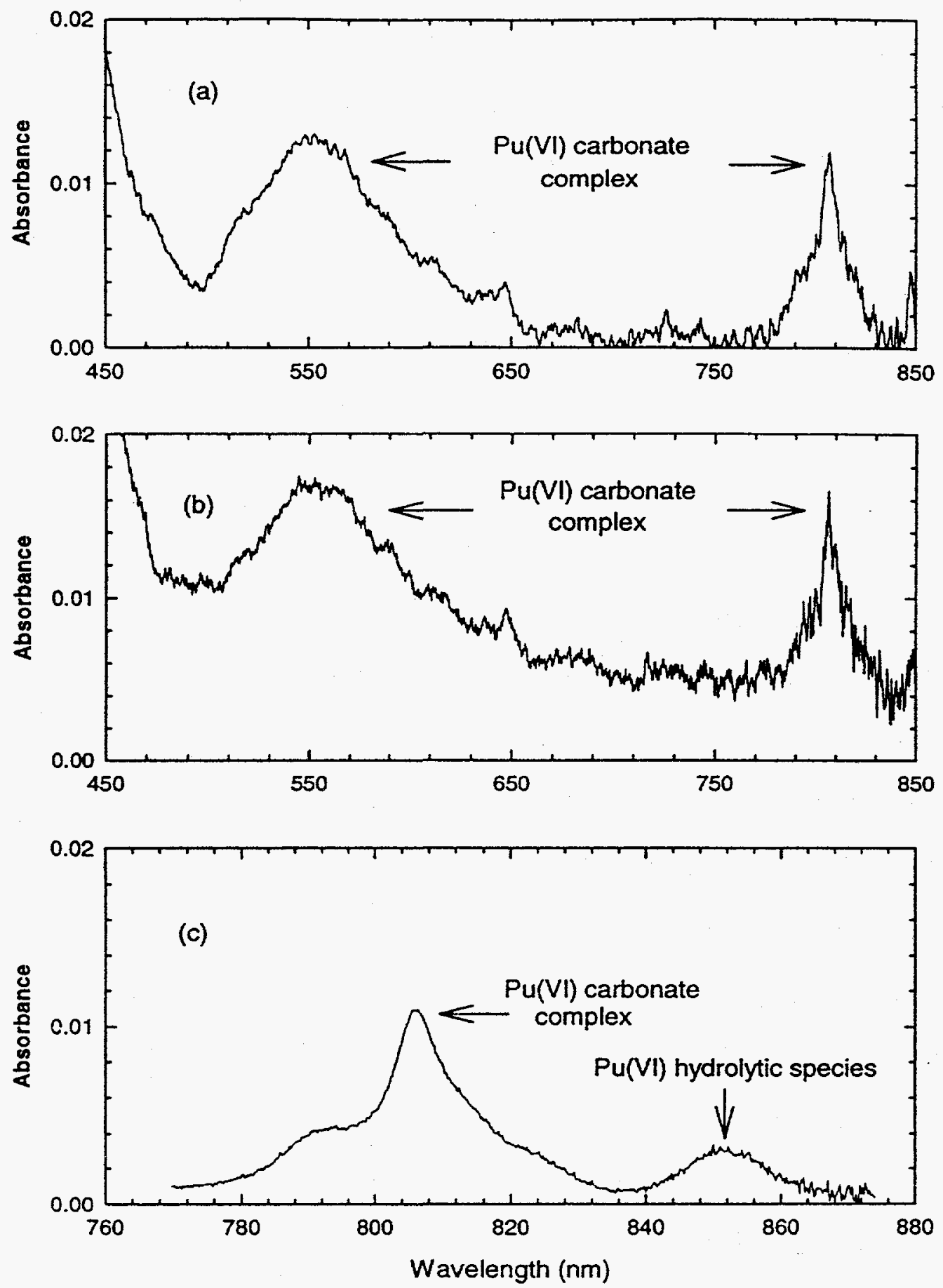

Fig. 2. Absorption spectra of $3 \times 10^{-4} \mathrm{M}$ Pu (VI) in WIPP Brine A at (a) 0, (b) 475, and (c) 945 days. Spectra $a$ and $b$ were obtained on the Hitachi model 340 spectrometer and spectrum $c$ was obtained using the Varian CARY -5 spectrometer (note different wavelength scale). 
for ERDA-6 brine and the higher concentration samples for G-Seep and DH-36 brines), we observed autoreduction of $\mathrm{Pu}(\mathrm{VI})$ to a $\mathrm{Pu}(\mathrm{V} / \mathrm{VI})$ mixture in solutions with comparable activity (i.e. the same dose rate). This phenomena was also reported elsewhere [14] in brine systems. Here there was a relatively rapid reduction of $\mathrm{Pu}(\mathrm{VI})$ due to radiolysis followed by a slower re-oxidation to $\mathrm{Pu}(\mathrm{VI})$ that was attributed to the radiolytic formation of oxygen chlorides in the brine. This initial reduction was not observed in our experiments when carbonate was present. The stability of the Pu(VI) carbonate complex in WIPP brine, however, is consistent with theoretical predictions [15] and experimental results [14] reported elsewhere. It has also been partly corroborated by results reported by others in the WIPP Project [16].

\section{Stability of Pu(VI) in ERDA-6 Brine}

The stability and speciation of Pu(VI) in ERDA-6 brine was significantly different than that observed in Brine $\mathrm{A}$ because of the absence of carbonate and bicarbonate. The absorption spectra of Pu(VI) in ERDA-6, as a function of time, are shown in Figure 3. The sample was analyzed spectroscopically at $6,77,280$ and 294 days after preparation.

The absorption spectra shown in Figure 3 are most similar to those for the hydrolytic species [see Figure 1]. At this $\mathrm{pH}$, the Pu(VI)-chloride complex would not be expected to successfully compete with hydrolysis [17]. The best interpretation of the $845 \mathrm{~nm}$ band is that it corresponds to a $\mathrm{Pu}(\mathrm{VI})$ species that is predominantly hydrolytic in nature. Further detailed studies are, however, needed to more fully evaluate the effect of ionic strength on band structure.

The redox stability of the Pu(VI)-hydrolytic species observed in ERDA-6 was less than, but comparable to, that observed for the Pu(VI)-carbonate complex in Brine A. There is a loss of approximately $25-30 \%$ of the absorbance at $845 \mathrm{~nm}$ when the 6-day and 295-day spectra are

compared. The total concentration of plutonium in this brine remained constant in both unfiltered and 

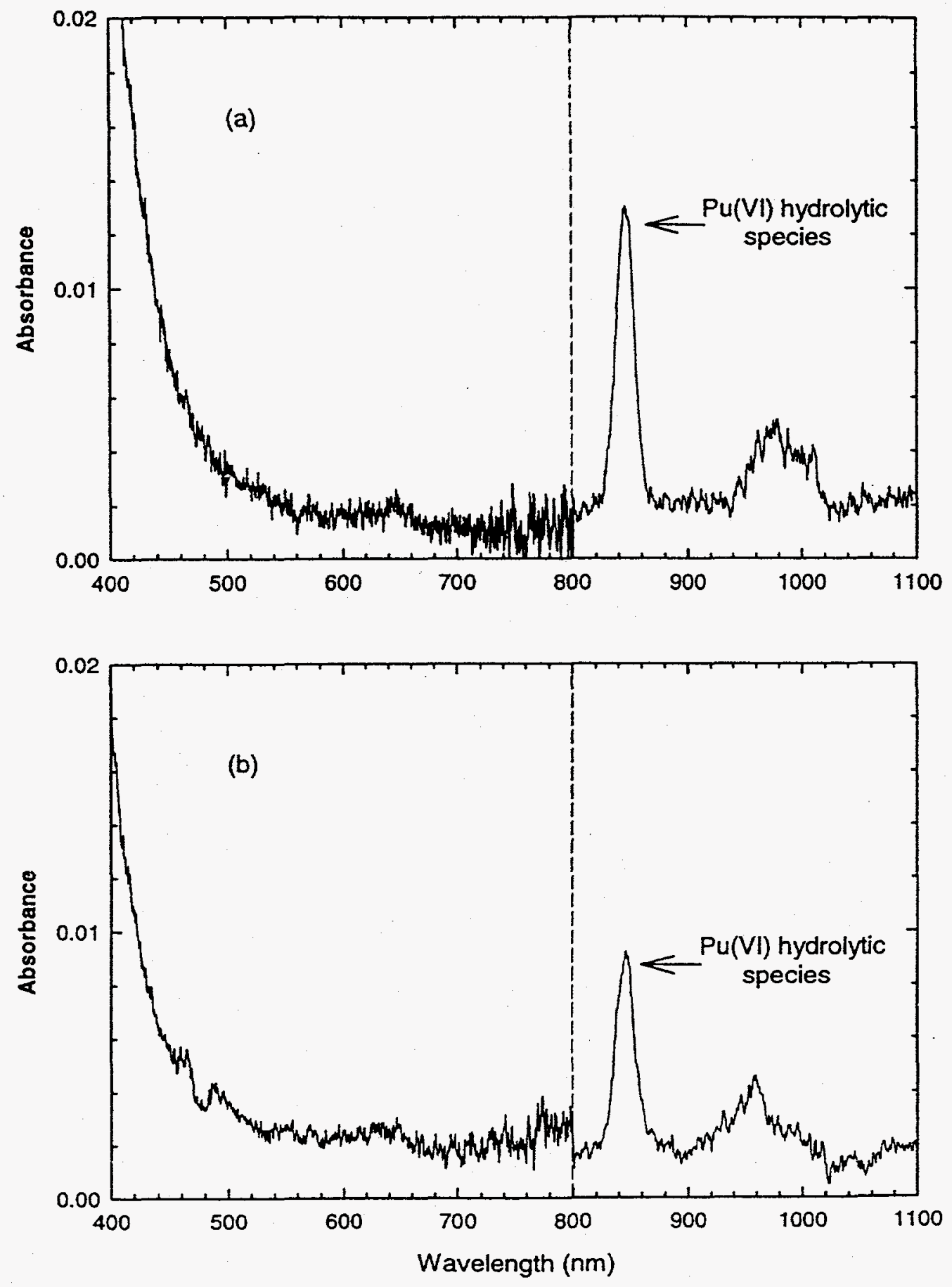

Fig. 3. Absorption spectra of $1.1 \times 10^{-4} \mathrm{MPu}$ (VI) in ERDA-6 brine at (a) 6, and (b) 294 days after sample preparation. 
0.2- $\mu$ filtered solutions, based on alpha-scintillation counting data. Reduction to $\mathrm{Pu}(\mathrm{V})$ is postulated, but $3 \times 10^{-5} \mathrm{M} \mathrm{Pu}(\mathrm{V})$ would not be observable spectroscopically $\left(\varepsilon=19 \mathrm{M}^{-1} \mathrm{~cm}^{-1}\right.$ at $\left.569 \mathrm{~nm}\right)$.

\section{Stability of Pu(VD) in DH-36 Brine}

The samples taken from the gas generation experiments GG-B3-41 and GG-B3-42 were spectroscopically analyzed to evaluate the stability of $\mathrm{Pu}(\mathrm{VI})$ in $\mathrm{DH}-36$ brine. There was no longer any spectroscopic evidence for Pu(VI) six days after sample preparation. There was, however, a small absorption (OD $=0.0015$ ) apparent at $569 \mathrm{~nm}$ that corresponds to $\mathrm{Pu}(\mathrm{V})$. This would account for approximately $75 \%$ of the plutonium initially present in solution. In spectra obtained at 280 and 295 days after sample preparation, the absorption spectrum was featureless. There was no evidence for either Pu(V) or Pu(VI). This suggests that reduction of the plutonium had proceeded to lower oxidation states of plutonium where polymerization would be expected. The speciation of the plutonium species remaining in solution was not established.

To determine the rate at which Pu(VI) was reduced in DH-36 brine, a new sample was prepared and spectroscopically monitored. These time-dependent spectra are shown in Figure 4 . The initial concentration of plutonium was $1.9 \times 10^{-4} \mathrm{M}$ and the $\mathrm{pH}_{\mathrm{OP}}$ was 6.1 . Initially, the $845-\mathrm{nm}$ band characteristic of the Pu(VI) hydrolytic species was observed. Two hours after sample preparation approximately $25 \%$ of the $\mathrm{Pu}(\mathrm{VI})$ was reduced to $\mathrm{Pu}(\mathrm{V})$. Three days after sample preparation, there was no spectroscopic evidence for $\mathrm{Pu}(\mathrm{VI})$, however, an increase in the $\mathrm{Pu}(\mathrm{V})$ absorption was observed. At higher plutonium concentrations $(0.0035 \mathrm{M})$, both filtered and unfiltered solutions of $\mathrm{Pu}(\mathrm{VI})$ in DH-36 brine were monitored spectroscopically for 337 days. For both solutions, the absorption spectrum was most similar to those of the Pu(VI) hydrolytic species and ERDA-6 brine. There were no significant differences noted between the filtered and unfiltered samples.

The long-term redox stability of $\mathrm{Pu}(\mathrm{VI})$ at this higher plutonium concentration was much greater than that noted at concentrations an order of magnitude lower. After 337 days, the spectrum 

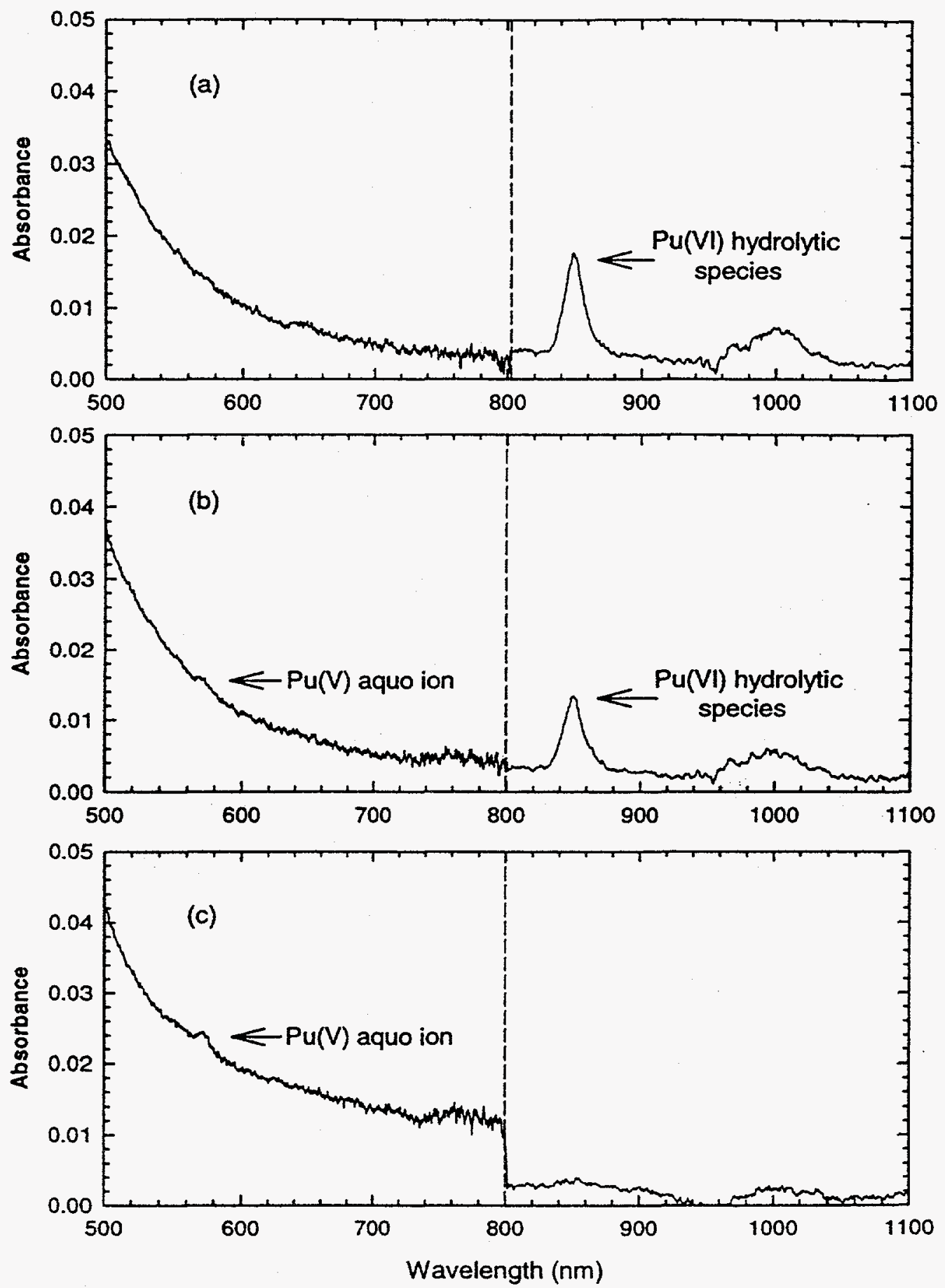

Fig. 4. Absorption spectra of $-10^{-4} \mathrm{M}$ Pu(VI) in DH-36 brine at (a) time $=0$, (b) after 2 hrs, and (c) at 3 days after sample preparation. 
obtained indicated that there were approximately equimolar concentrations of $\mathrm{Pu}(\mathrm{V})$ and $\mathrm{Pu}(\mathrm{VI})$ in solution, estimated to be 0.0011 and $0.0014 \mathrm{M}$ respectively. This finding contrasts with the complete and rapid reduction observed at $\sim 10^{-4} \mathrm{M}$ plutonium concentrations. Autoradiolysis at comparable plutonium concentrations resulted in complete conversion of $\mathrm{Pu}(\mathrm{VI})$ to $\mathrm{Pu}(\mathrm{IV})$ for low ionic strength solutions at $\mathrm{pH}_{\mathrm{OP}}=3[13]$. The combination of higher $\mathrm{pH}$, high ionic strength, and the radiolyticallyinduced changes in the brine stabilized the $\mathrm{Pu}(\mathrm{V} / \mathrm{VI})$ against autoreduction to $\mathrm{Pu}(\mathrm{IV})$. This was presumably due to the radiolytic formation of oxygen chlorides in the brine [14].

Although there are a number of questions raised by these results that cannot be fully resolved, there are some observations related to the redox stability and speciation of Pu(VI) in DH-36 that were made. First, the initial speciation of $\mathrm{Pu}(\mathrm{VI})$ appears to be a hydrolytic species. This proposed assignment is based on spectral comparisons with Pu(VI) in ERDA-6 and non-complexing medias. This species is rapidly reduced at plutonium concentrations of $-10^{-4} \mathrm{M}$. This reduction is fast relative to autoradiolysis and is caused by a reducing agent in the brine. We could not establish the nature of the reducing agent or the plutonium species generated, although a $\mathrm{Pu}(\mathrm{IV})$ aggregate, perhaps a polymeric species, is likely at the near-neutral $\mathrm{pH}$ of the brine.

At concentrations of plutonium $>10^{-3} \mathrm{M}$, the predominant species were $\mathrm{Pu}(\mathrm{V})$ and hydrolyzed $\mathrm{Pu}(\mathrm{VI})$. These oxidation states of plutonium have persisted for a year. The concentration of $\mathrm{Pu}(\mathrm{VI})$ and $\mathrm{Pu}(\mathrm{V})$ appear to reach steady-state with time.

\section{Stability of Pu(VI) in G-Seep brine}

The samples of $10^{-4} \mathrm{MPu}(\mathrm{VI})$ in G-Seep brine were taken from the gas generation experiments GGB2-41 and GG-B2-42. The time-dependent spectra are presented in Figure 5. Six days after sample preparation, the dominant species appears to be the Pu(VI) hydrolytic species, with a maximum absorption at $845 \mathrm{~nm}$. The estimated concentration of this species was $4 \times 10^{-5} \mathrm{M}$, about $40 \%$ of the 

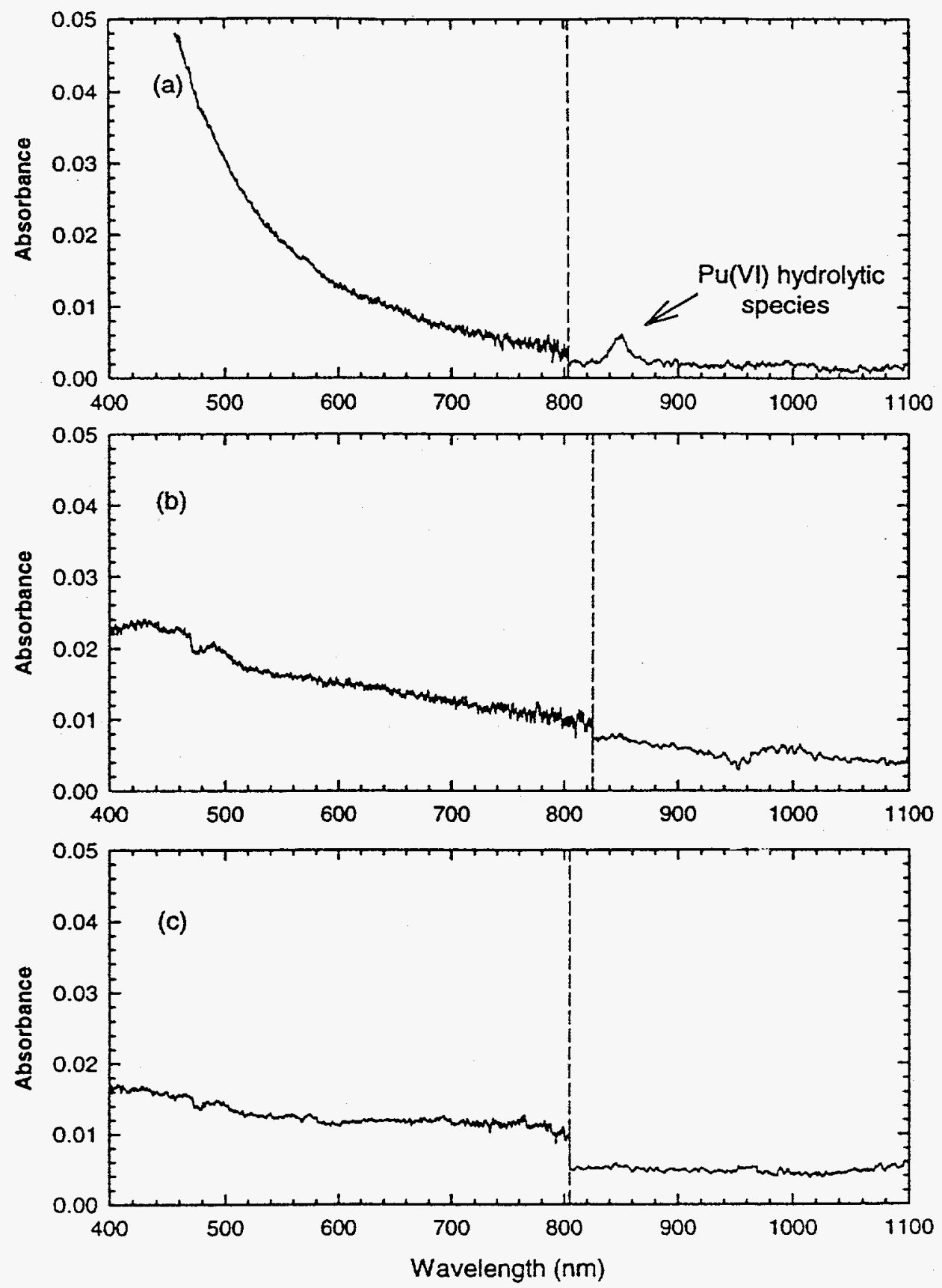

Fig. 5. Absorption spectra of $1.1 \times 10^{-4} \mathrm{M}$ Pu (VI) in G-Seep brine at (a) 6, (b) 77, and (c) 280 days after sample preparation. 
total plutonium initially present in solution. An absorption band at shorter wavelength was also present.

At 77 days, there was no spectral evidence of $\mathrm{Pu}(\mathrm{VI})$. After 280 days, there was no absorbance characteristic of dissolved plutonium species. Based on the alpha-scintillation counting results, however, over half the plutonium originally present in solution was still there. The nature of this plutonium species was not established.

As with the $\mathrm{DH}-36$ brine sample, a $0.0035 \mathrm{M} \mathrm{Pu}(\mathrm{VI})$ solution in G-Seep brine was prepared. Plutonium solutions for both the filtered and unfiltered brine were monitored the same way. No significant differences were observed between the spectra obtained. At this higher plutonium concentration the hydrolytic species appears to be predominant, with an absorption band at $\sim 845 \mathrm{~nm}$. A slow decrease in the concentration of this species was noted with time, along with a corresponding increase in the concentration of $\mathrm{Pu}(\mathrm{V})$ at $569 \mathrm{~nm}$. After 337 days, the concentration of the $\mathrm{Pu}(\mathrm{VI})$ hydrolytic species was $0.0014 \mathrm{M}$ and the concentration of $\mathrm{Pu}(\mathrm{V})$ was $0.0008 \mathrm{M}$. Additionally, the total plutonium concentration decreased by $40 \%$.

\section{Discussion and Summary of Observations}

Plutonium at concentrations of $-10^{-4} \mathrm{M}$ remained in solution in both synthetic brines investigated. In Brine A, a Pu(VI)-carbonate complex was observed that has been stable for over two years. This complex appears to stabilize Pu(VI) towards autoreduction to Pu(V). In ERDA-6, the Pu(VI) species was predominantly hydrolytic in nature and was partly reduced to $\mathrm{Pu}(\mathrm{V})$ over the course of a year.

$\mathrm{Pu}(\mathrm{VI})$ was significantly less stable in the WIPP brines collected underground. In DH-36, $\mathrm{Pu}(\mathrm{VI})$ was rapidly reduced at total $\mathrm{Pu}$ concentrations of $-10^{-4} \mathrm{M}$ or less. This occurred in the timeframe of a few hours. The reducing agent in this process was not identified. It was likely due to the presence of trace constituents, such as reduced metals or organics, in the groundwater. At plutonium concentrations above $10^{-3} \mathrm{M}, \mathrm{Pu}(\mathrm{VI})$ was much more stable in both DH-36 and G-Seep. 
When reduction occurred in DH-36, most of the plutonium remained in solution as an undefined species that did not absorb strongly in the visible-NIR range. The loss of plutonium was probably due to precipitation of plutonium phases. The absence of absorption bands characteristic of Pu(III, IV, V, VI) for the plutonium remaining in solution suggests that a colloidal or polymeric species may be present. This, however, was not directly established in our work. In G-Seep, the initial species was also predominantly hydrolytic. This was reduced to $\mathrm{Pu}(\mathrm{V})$ which was subsequently reduced to an unidentified species that mostly remained in solution.

Finally, it is important to qualify these results relative to the conditions expected in the WIPP. Since the Pu(VI) in our studies is introduced at high initial concentrations, we potentially have a radiolysis-dominated system that is more oxidizing than that expected in the WIPP. Reducing agents introduced by waste emplacement itself, such as organic waste, iron etc., will potentially have an important effect on the reduction and/or removal of plutonium. These factors also need to be taken into account to more fully establish the expected speciation and solubility of plutonium in the WIPP.

\section{Acknowledgement}

The authors wish to acknowledge Larry Brush (SNL) and Martin Molecke (SNL) who directed this work and provided many useful comments and suggestions; Craig Novak for providing comments on the data reported; and Hans Weger for the providing the Pu(VI)-chloride spectrum reported.

This work was supported by the U.S. Department of Energy, under contract W-31-109-ENG38. All work was performed as part of the laboratory investigation in support of the Waste Isolation Pilot Plant Gas Generation Program under contracts 78-1500 and 67-8601. 


\section{References}

3. Reed, D.T., S. Okajima, L.H. Brush, and M.A. Molecke. 1993. "Radiolytically-Induced Gas Production in Plutonium-Spiked WIPP Brine," Scientific Basis for Nuclear Waste Management XVI, Materials Research Society Symposium Proceedings, Boston, MA, November 30-December 4, 1992. Eds. C.G. Interrante and R.T. Pabalan. SAND92-7283C. Pittsburgh, PA: Materials Research Society. Vol. 294, 431-438.

4. Brush, L.H., D. Grbic-Galic, D.T. Reed, X. Tong, R.H. Vreeland, and R.E. Westerman. 1991. "Preliminary Results of Laboratory studies of Repository Chemistry for the waste Isolation Pilot Plant," Scientific Basis for Nuclear Waste Management XIV, Materials Research Society Symposium Proceedings, Boston, MA, November 26-29, 1990. Eds. T.A. Abrajano, Jr. and L.H. Johnson. SAND90-1031C.Pittsburgh, PA: Materials Research Society. Vol. 212, 893-900.

5. Brush, L.H. 1990. Test Plan for Laboratory and Modeling Studies of Repository and Radionuclide Chemistry for the waste Isolation Pilot Plant. SAND90-0266. Albuquerque, NM: Sandia National Laboratories.

6. Lappin, A.R., R.L. Hunter, D.P. Garber, and P.B. Davies, eds. 1989. Systems Analysis, Long-Term Radionuclide Transport, and Dose Assessments, Waste Isolation Pilot Plant (WIPP), Southeastern New Mexico; March 1989. SAND89-0462. Albuquerque, NM: Sandia National Laboratories.

7. Felmy, A.R., D. Rai, J.A. Schramke, and J.L. Ryan. 1989. "The Solubility of Plutonium Hydroxide in Dilute solution and in High-Ionic-Strength Chloride Brines," Radiochimica Acta. Vol. 48 , no. $1 / 2,29-35$.

8. Felmy, A.R., D. Rai, and M.J. Mason. 1992. "The Solubility of Hydrous Thorium(IV) Oxide in Chloride Media: Development of an Aqueous Ion-Interaction Model, "Radiochimica Acta. Vol. 55, no. $4,177-185$.

9. Newton, T.W., and J.C. Sullivan. 1986. "Actinide Carbonate Complexes in Aqueous Solution," Handbook on the Physics and Chemistry of the Actinides. Eds. A.J. Freeman and C. Keller. New York, NY: North-Holland. Vol. 4, 387-406.

10. Katz, J.J., G.T. Seaborg, and L.R. Morss, eds. 1986. The Chemistry of the Actinide Elements. 2nd ed. New York, NY: Chapman and Hall. Vol. I, Figure 7.100.

11. Varlashkin, P.G., G.M. Begun, and J.R. Peterson. 1984. "Electrochemical and Spectroscopic Studies of Plutonium in Concentrated Aqueous Carbonate and Carbonate-Hydroxide Solutions," Radiochimica Acta. Vol. 35, no. 4, 211-218. 
12. Okajima, S., D.T. Reed, J.V. Beitz, C.A. Sabau, and D.L. Bowers. 1991. "Speciation of Plutonium(VI) in Near-Neutral Solutions via Laser Photoacoustic Spectroscopy, " Radiochimica Acta. Vol. 52-53, pt. 1, 111-117.

13. Okajima, S., and D.T. Reed. 1993. "Initial Hydrolysis of Plutonium(VI)," Radiochimica Acta. Vol. 60, no. 4, 173-184.

14. Kim, J.I., C. Lierse, K. Bueppelmann, and S. Magirius. 1987. "Radiolytically Induced Oxidation Reactions of Actinide Ions in Concentrated Salt Solutions," Scientific Basis for Nuclear Waste Management $X$, Materials Research Society symposia Proceedings, Boston, MA, December 1-4, 1986. Eds. J.K. Bates and W.B. Seefeldt. Pittsburgh, PA: Materials Research Society. Vol. $84,603-612$.

15. Aston, S.R. 1980. "Evaluation of the Chemical Forms of Plutonium in Seawater," Marine Chemistry. Vol. 8, no. 4, 319325 .

16. Nitsche, H., K. Roberts, R. Xi, T. Prussin, K. Becraft, I. Al Mahamid al Rifai, H.B. Silber, S.A. Carpenter, R.C. Gatti, and C.F. Novak. 1995. "Long-Term Plutonium Solubility and Speciation Studies in a Synthetic Brine," Actinide Chemistry Research Supporting the Waste Isolation Pilot Plant (WIPP): FY94 Results. SAND94-2274. Albuquerque, NM: Sandia National Laboratories. 65-84.

17. Cleveland, J.M. 1979. The Chemistry of Plutonium. 2nd printing. La Grange Park, IL: American Nuclear Society. p. 453 . 
This page intentionally left blank. 
Solubility of $\mathrm{Nd}$ in Brine 
This page intentionally left blank. 


\author{
Solubility of $\mathrm{Nd}$ in Brine \\ F. I. Khalili, V. Symeopoulos, J.-F. Chen \\ and G. R. Choppin \\ Department of Chemistry \\ Florida State University \\ Tallahassee, FL. 32306-3006
}

\begin{abstract}
The solubility of $\mathrm{Nd}$ (III) has been measured at $23 \pm 3{ }^{\circ} \mathrm{C}$ in a synthetic brine at $\mathrm{pcH} 6.4,8.4,10.4$ and 12.4 . The brine consisted predominantly of $(\mathrm{Na}+\mathrm{K}) \mathrm{Cl}$ and $\mathrm{MgCl}_{2}$ with an ionic strength of $7.8 \mathrm{M}$ (9.4m) a solid compound of $\mathrm{Nd}$ (III) at each $\mathrm{pcH}$ was assigned from $\mathrm{X}-$ ray diffraction patterns. The log values of the experimental solubilities decrease from -3 at pcH 6.4 to -5.8 at $\mathrm{pcH} 8.4$; at pcH 10.4 and 12.4 the solubility was below the detection limit of -7.5 . The experimental solubility does not follow closely the variation with pcH estimated from modeling of the species in solution in equilibrium with the Nd solid using S.I.T.
\end{abstract}




\section{INTRODUCTION}

The solubility of the radionuclides in radioactive wastes is necessary information for assessment of the disposal of such wastes. Among these radionuclides plutonium is of major interest because of the long half life of the major isotope $(A=239)$. The interpretation of data on the solubility of plutonium is made rather difficult by the uncertainty of its redox behavior as well as lack of knowledge about the solids likely to be formed. To aid in such interpretation, it is useful to study species of fixed oxidation state whose chemical behavior resembles closely that of plutonium in that oxidation state. Appropriate oxidation state analogs are Nd(III), Th(IV) and U(VI) - as uranyl, $\mathrm{UO}_{2}^{2+}$ - for $\mathrm{Pu}(\mathrm{III}), \mathrm{Pu}(\mathrm{IV})$ and $\mathrm{Pu}(\mathrm{VI}) . \mathrm{Th}(\mathrm{IV})$ and $\mathrm{U}(\mathrm{VI})$ are also of interest as they constitute part of the radionuclide content of most nuclear wastes.

We have reported on the solubilities of Th(IV) (I) and U(VI) (2) in a synthetic brine of relevance to the WIPP repository site. In this paper we report the results of a similar investigation of the solubility of $\mathrm{Nd}^{3+}$ in the same synthetic brine at $\mathrm{pcH}$ values between 6.4 and 12.4 .

\section{EXPERIMENTAL}

Reagents and Solutions: The synthetic brine was prepared from analytical reagents with distilled, deionized water according to the formulation in Table 1. The neodymium salt was reagent grade 
TABLE 1

Components of Synthetic Brine

Compound

$\mathrm{NaCl}$

$\mathrm{Na}_{2} \mathrm{SO}_{4}$

$\mathrm{NaHCO}_{3}$

$\mathrm{NaBr}$

$\mathrm{KCl}$

$\mathrm{CaCl}_{2}$

$\mathrm{MgCl}_{2} \cdot 6 \mathrm{H}_{2} \mathrm{O}$

$\mathrm{Na}_{2} \mathrm{~B}_{4} \mathrm{O}_{7} .10 \mathrm{OH}_{2} \mathrm{O}$

Ionic Strength

\section{Grams per Liter}

100

6.2

0.96

0.52

57.2

1.66

292.1

2.0

$7.8 \mathrm{M}(9.4 \mathrm{~m})$ 
$\mathrm{NdCl}_{3} \cdot 6 \mathrm{H}_{2} \mathrm{O}$ (Aldrich). All other chemicals were also reagent grade and used without further purification.

The solutions were prepared at $\mathrm{pcH} 6.3$ with $1.3 \mathrm{~L}$ of brine in each of 2 beakers (N.B., $\mathrm{pcH}=-\log \left[\mathrm{H}^{+}\right.$concentration]). The $\mathrm{pcH}$ was adjusted to 6.3 with concentrated $\mathrm{HCl}$ solution and 3.2 millimoles of $\mathrm{NdCl}_{3} \cdot 6 \mathrm{H}_{2} \mathrm{O}$ added. Most of the $\mathrm{Nd}$ (III) precipitated as the amorphous hydroxide immediately. This constituted an "oversaturation" experiment. All measurements were performed at laboratory temperature, $23 \pm 3^{\circ} \mathrm{C}$.

Solubility: Initially, the solubilities at pcH 6.3 and 8.4 were studied by oversaturation as follows. The $\mathrm{pcH}$ of $1.3 \mathrm{~L}$ of the synthetic brine was adjusted to 6.3 by addition of concentrated HCl to two breakers followed by addition of $3.2 \mathrm{millimoles}$ of $\mathrm{NaCl}_{3} \cdot 6 \mathrm{H}_{2} \mathrm{O}$ to each. To the same volume of brine in two other breakers, saturated $\mathrm{NaOH}$ solution was added to adjust the pcH to 8.4 , then 3.7 moles $\mathrm{NdCl}_{3} \cdot 6 \mathrm{H}_{2} \mathrm{O}$ were added to each.

Solutions of brine at $\mathrm{pcH} 10.4$ were prepared (oversaturation) in two ways:

a) without massive brine solid. The $\mathrm{pcH}$ of $2 \mathrm{~L}$ of brine was adjusted to ca. 10 by adding $265 \mathrm{~mL}$ of saturated $\mathrm{NaOH}$ solution. The solids formed, mainly $\mathrm{Mg}(\mathrm{OH})_{2}$, were removed by filtration and $\mathrm{NaCl}$ was added to the filtrate in order to readjust the ionic strength. Two samples of $0.5 \mathrm{~L}$ each of the filtrate solution were transferred to separate beakers after which 2.0 millimoles of $\mathrm{NdCl}_{3} \cdot 6 \mathrm{H}_{2} \mathrm{O}$ were added to each. Finally, the $\mathrm{pcH}$ was adjusted to 10.4. This procedure 
retained the ionic strength at $9.4 \mathrm{~m}$ with the $\mathrm{Mg}^{2+}$ replaced by $\mathrm{Na}^{+}$.

b) with massive brine solid. In each of two beakers, $1.3 \mathrm{~L}$ of the brine added had the $\mathrm{pcH}$ adjusted to 10.4 by saturated $\mathrm{NaOH}$ solution followed by addition of 2.0 mmoles of $\mathrm{NdCl}_{3} \cdot 6 \mathrm{H}_{2} \mathrm{O}$. In these experiments, the precipitation of the $\mathrm{Mg}^{2+}$ results in a decreased ionic strength to ca. $5.3 \mathrm{~m}$.

For the experiments at $\mathrm{pcH}$ 12.4, samples with and without brine solid were used.

a) without massive brine solid. Two samples of $0.5 \mathrm{~L}$ of the filtrate prepared for the $\mathrm{pcH} 10.4$ experiments were transferred into two plastic bottles and the $\mathrm{pcH}$ adjusted to 12.4 with saturated sodium hydroxide. After addition of 1.8 mmole of $\mathrm{NaCl}_{3} \cdot 6 \mathrm{H}_{2} \mathrm{O}$ to each bottle, they were flushed with $\mathrm{N}_{2}$ and tightly closed. As at pcH 10.4, the ionic strength was maintained but the brine constituents have changed.

b) with massive brine solids. The brine was prepared as described for the $\mathrm{pcH} 10.4$ samples with adjustment of the pcH to 12.4 . As at $\mathrm{pcH} 10.4$, the ionic strength was reduced (to ca. $5.3 \mathrm{~m})$.

The pcH 8.4 undersaturation experiments were conducted with the solutions from the experiments at $\mathrm{pcH} 10.4$ without massive solid after steady state had been attained at that pcH. The pcH was adjusted to 8.4 with concentrated $\mathrm{HCl}$ and sampling continued. 
All the bottles were flushed with nitrogen and tightly capped. After reopening and sampling, the bottles were flushed again with $\mathrm{N}_{2}$ and resealed.

Measurement of $\mathrm{pcH}$ : A glass combination electrode with the reference cell filled with a modified brine was used in order to minimize liquid junction effect. The brine used in the reference cell did not contain $\mathrm{Na}_{2} \mathrm{SO}_{4}, \mathrm{NaHCO}_{3}$ nor $\mathrm{Na}_{2} \mathrm{~B}_{4} \mathrm{O}_{7} \cdot 10 \mathrm{HO}$ to avoid their buffering effect. The electrode was calibrated for proton concentrations by the Gran method (3).

Separation and Analysis: Initially, a process of hydroxide precipitations and elution from columns of anion resin was used. Twenty $\mathrm{mL}$ samples of the brine had $300 \mathrm{mg}$ of $\mathrm{Fe}$ (III) added followed by precipitation with concentrated sodium hydroxide solution. After precipitate washing, acid dissolution and alkali reprecipitation, the washed precipitate was dissolved in sufficient concentrated $\mathrm{HCl}$ solution to yield an $8 \mathrm{M} \mathrm{HCl}$ solution. This solution was placed on the top of a column of Dowex-1 anion exchange resin. A second volume of $8 \mathrm{M} \mathrm{HCl}$ washed all the $\mathrm{Nd}$ (III) through while retaining the Fe(III). The eluant was evaporated to dryness and redissolved in $0.1 \mathrm{M} \mathrm{HCl}$. This solution, $20 \mathrm{~mL}$, was passed through a column of Dowex-50 cation exchange resin followed by passage of $100 \mathrm{ml}$ of $0.1 \mathrm{M} \mathrm{HCl}$, This was followed by elution of the Nd(III) with $35 \mathrm{~mL}$ of $6 \mathrm{M} \mathrm{HCl}$ solution. The yield of $\mathrm{Nd}$ (III) was found to be $100( \pm 4) \%$ using spiked brine samples. The concentration of $\mathrm{Nd}$ (III) in the eluant was measured using Arsenazo- 
III (4) on a Cary-14 rebuilt (On-Line) spectrometer. The detection limit was $3 \times 10^{-8} \mathrm{M}$ Nd(II).

In the later experiments, a simpler method was used which involved extraction of $\mathrm{Nd}$ (III) from the brine using a 1-butanol solution of Chlorophosphonazo III (5). The Cary-14 was used for the spectrophotometric determination of the concentration of Nd(III) in the butanol phase. The detection limit for Nd(III) by this method was $5 \times 10^{-7} \mathrm{M}$ and the recovery efficiency was $96 \pm 4 \%$. X-Ray Measurements: Samples of the solid present at steady state were dried and analyzed by $\mathrm{X}$-ray diffraction with a siemens spectrometer using $\operatorname{CuK} \alpha(1.54 \dot{A})$ radiation.

\section{RESULTS AND DISCUSSION}

The powder $\mathrm{X}$-ray diffraction patterns were matched for spacing and relative intensity of the lines with the patterns of a number of lanthanide compounds. The result was a best match with the solids listed in Table 2 .

The variation of solubility with time is shown for the pcH 6.4 and 8.4 systems in Figure 1 . For $\mathrm{pcH} 10.4$ and 12.4, the solubilities were below the analytical limit (s $3 \times 10^{-8} \mathrm{M}$ ) for all measurements. The measured steady state solubilities are listed in Table 2. For the $\mathrm{pcH} 6.4$ and 8.4 solutions, the spectra indicate the presence of amorphous $\mathrm{Nd}(\mathrm{OH})_{3}$. At $\mathrm{pcH} 10.4$ in the absence of massive brine solids, $\mathrm{Nd}_{2}\left(\mathrm{CO}_{3}\right)_{3} \cdot 8 \mathrm{H}_{2} \mathrm{O}$ was indicated by the $\mathrm{X}$-ray data as the controlling solid phase. It was more difficult to detect the presence of neodymium compounds in the presence of massive 
TABLE 2

Solubility of $\mathrm{Nd}^{3+}$ in Brine

$\mathrm{T}=25^{\circ} \mathrm{C}$

\begin{tabular}{llll} 
pcH & \multicolumn{2}{c}{ Solubility $(\mathrm{M})$} & Time (d)/Condition \\
6.4 & $\begin{array}{l}\text { a) } 8.3( \pm 0.1) 10^{-4} \\
\text { b) } 1.2( \pm 0.1) 10^{-3}\end{array}$ & $187 /$ oversaturated \\
8.4 & $\begin{array}{l}\text { a) } 2.3( \pm 0.1) \times 10^{-6} \\
\text { b) } 1.8( \pm 0.1) \times 10^{-6}\end{array}$ & \\
8.4 & a) $1.5( \pm 0.1) \times 10^{-6}$ & $264 /$ oversaturated \\
& b) $1.3( \pm 0.1) \times 10^{-6}$ &
\end{tabular}

10.4

$\mathrm{a} \& \mathrm{~b}$ less than $3( \pm 3) \times 10^{-8}$

10.4

a \& b less than $3( \pm 3) \times 10^{-8}$

$\geq 100 /$ without solid

$2100 /$ with solid

Solid

Amorphous $\mathrm{Nd}(\mathrm{OH})_{3} \cdot \mathrm{nH}_{2} \mathrm{O}$

Amorphous $\mathrm{Nd}(\mathrm{OH})_{3} \cdot \mathrm{nH}_{2} \mathrm{O}$

Amorphous $\mathrm{Nd}(\mathrm{OH})_{3} \cdot \mathrm{nH}_{2} \mathrm{O}$ $\mathrm{Nd}_{2}\left(\mathrm{CO}_{3}\right)_{3} \cdot 8 \mathrm{H}_{2} \mathrm{O}$

uncertain

12.4

$a \& b$ less than $3( \pm 3) \times 10^{-8}$

$2100 /$ without solid

$\mathrm{NdO}(\mathrm{OH})+$ $\mathrm{Nd}(\mathrm{OH})_{3}$

12.4

$a \& b$ less than $3( \pm 3) \times 10^{-8}$

$\geq 100 /$ with solid

uncertain 


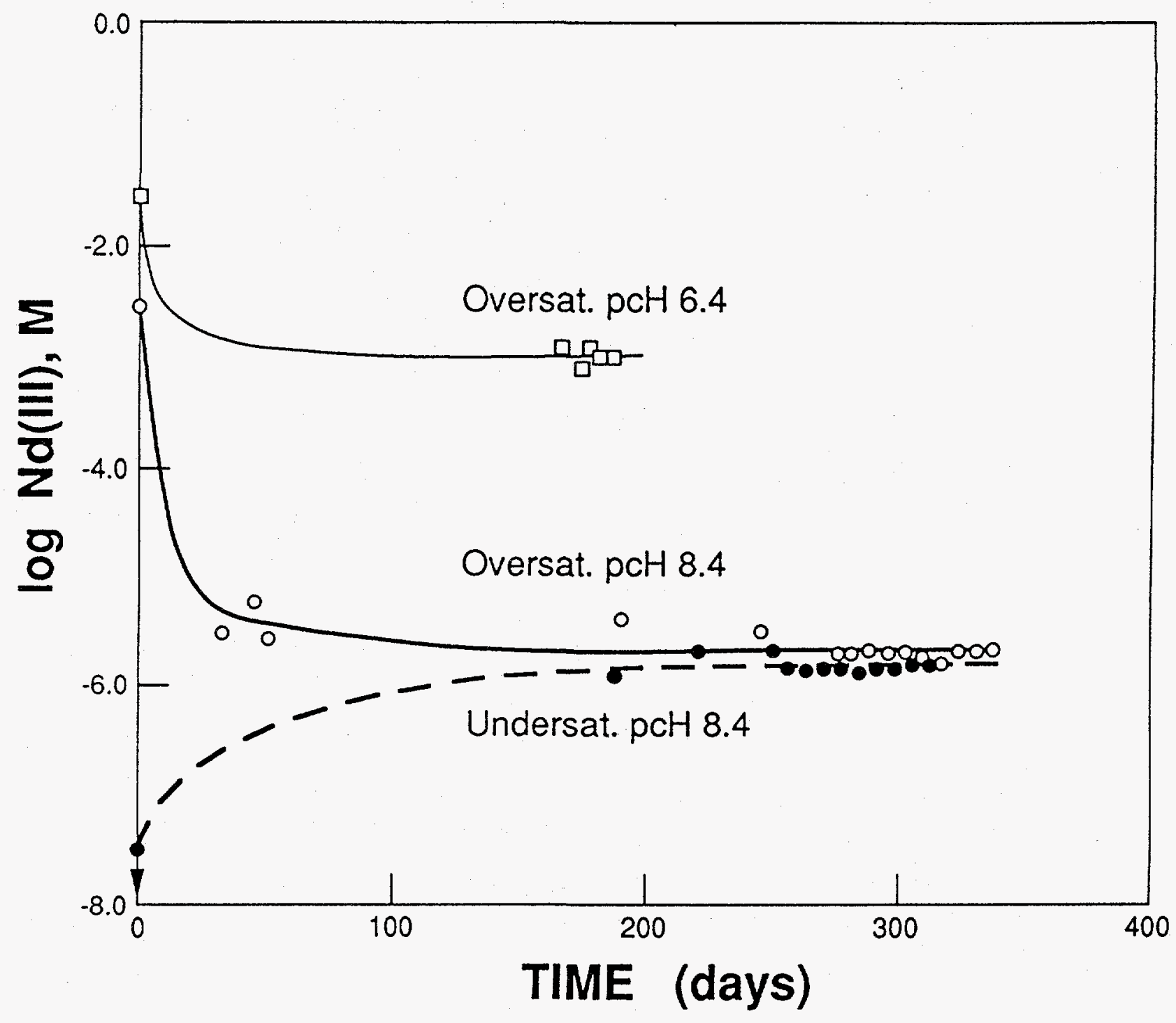

Figure 1. Plot of the total concentration in solution as a function of time. 
amounts of solid (mostly $\mathrm{Mg}(\mathrm{OH})_{2}, \mathrm{NaCl}$ and $\mathrm{KCl}$ ) at $\mathrm{pCH}=10.4$ and 12.4 due to its low contribution to the total solid phase. At pcH 12.4 in the absence of massive solids, the solid phase best fitted spectra of a mixture of $\mathrm{NdO}(\mathrm{OH})$ and $\mathrm{Nd}(\mathrm{OH})_{3}$.

The modeling calculations of neodymium solubility in brine as a function of $\mathrm{pcH}$ were based on thermodynamic data from various sources (e. g. ref. 6 and 7 ). The actual values are listed in Table 3. The computer codes used for specification were Haltafall (8) and Solgaswater (9). Activity coefficients corrections were made using the Specific Interaction Theory (SIT) (10). In these calculations, the solid phase limiting the Nd(III) solubility at each pcH value is $\mathrm{Nd}(\mathrm{OH})_{3(\mathrm{am})}$ for $\mathrm{pCH} 6.4$ and $8.4, \mathrm{Nd}\left(\mathrm{CO}_{3}\right)_{3} \cdot 8 \mathrm{H}_{2} \mathrm{O}$ for $\mathrm{pcH} 10.4$ and $\mathrm{Nd}(\mathrm{OH})_{3}+\mathrm{NdO}(\mathrm{OH})$ for $\mathrm{pcH} 12.4$.

The experimental solubilities are presented in Figure 2. Also shown are two lines representing the calculated solubility; the dashed line assumes $\mathrm{Nd}(\mathrm{OH})_{3}$ is the highest hydrolytic species in solution while the solid line was calculated with the inclusion of $\mathrm{Nd}(\mathrm{OH})_{4}^{-}(11)$. The experimental solubility decreases from pcH 6.4 to $\mathrm{pcH} 10.4$. At $\mathrm{pcH} 10.4$ and 12.4 we can report only upper limits. At these latter $\mathrm{pcH}$ values, there is rather serious disagreement between the experimental and calculated values which may reflect problems of estimation of the stability constants and solubility constants by SIT for the high ionic strength of the brine. Figure 3 shows the calculated concentrations of the major solution species as a function of $\mathrm{pcH}$. Chloride complexation of $\mathrm{Nd}$ (III) was not included in Figure 3 as it would be relatively constant in these 


\section{TABLE 3}

Constants Used in Calculations

Species

$\mathrm{Nd}(\mathrm{OH})^{2+}$

$\mathrm{Nd}(\mathrm{OH})_{2}{ }^{+}$

$\mathrm{Nd}(\mathrm{OH})_{3}^{0}$ (aq)

$\mathrm{Nd}\left(\mathrm{CO}_{3}\right)$

$\mathrm{Nd}\left(\mathrm{CO}_{3}\right)_{2}$

$\mathrm{Nd}\left(\mathrm{CO}_{3}\right)_{3}^{3-}$

$\mathrm{Nd}\left(\mathrm{CO}_{3}\right)_{4}^{5-}$ $\log \beta$

$-7.8$

$-16.5$

$-24.9$

6.66

11.6

12.5

13.7 


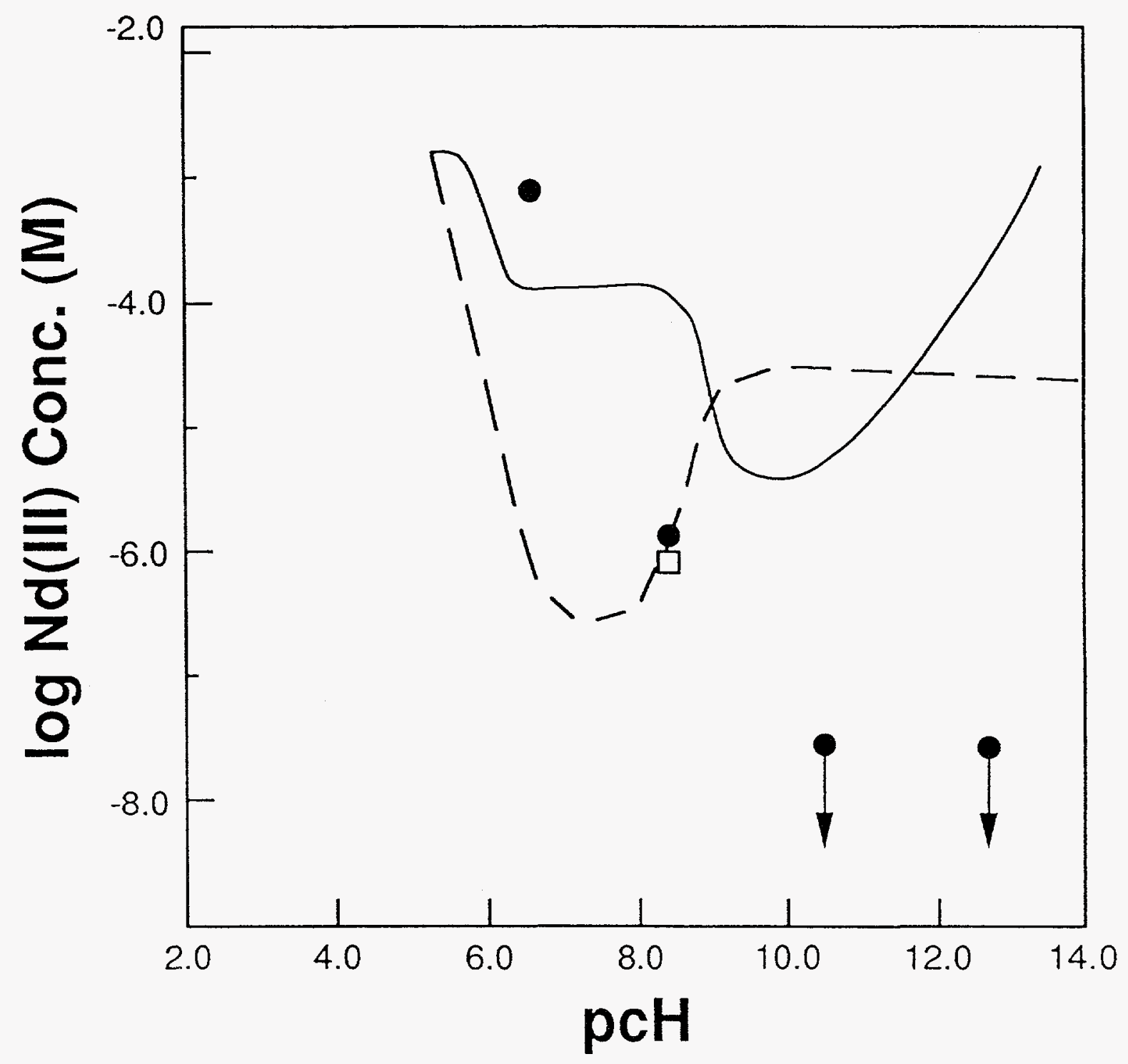

Figure 2. Variation of the calculated concentrations of the major $\mathrm{Nd}(\mathrm{III})$ soluble species as a function of $\mathrm{pcH}$ compared to measured solubility. 


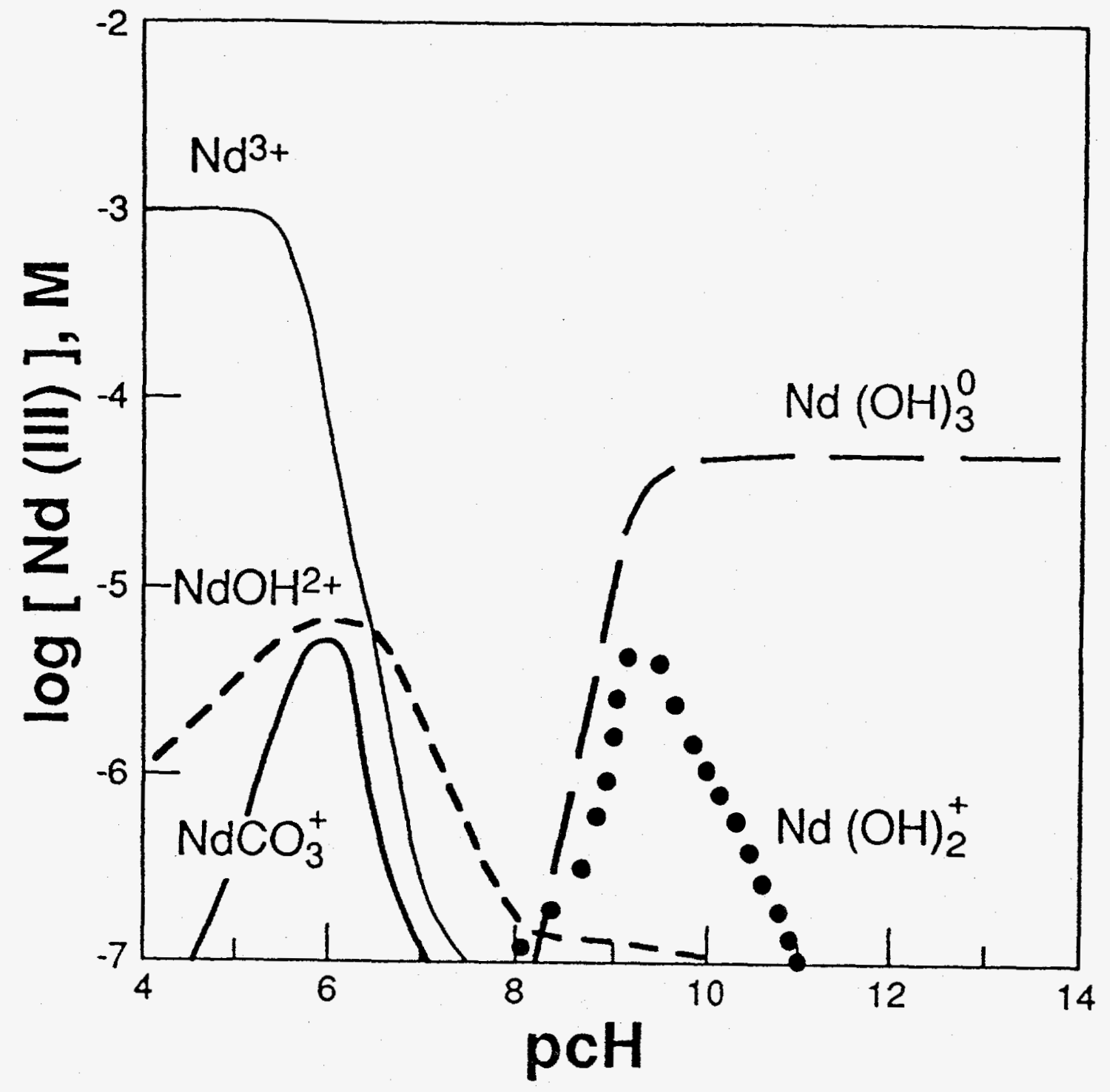

Figure 3. Calculated concentrations of hydrolytic and carbonato species of $\mathrm{Nd}(\mathrm{III})$ as a function of $\mathrm{pcH}$ and $[\mathrm{Nd}]_{\mathrm{T}}=10^{-3} \mathrm{M}$. 
systems. The curves in Figure 3 suggest that the disagreement at $\mathrm{pcH} 10.4$ and 12.4 is due to incorrect values of the constants used to calculate the concentrations of $\mathrm{Nd}(\mathrm{OH})_{3(\mathrm{aq})}$ and the solubility product for $\mathrm{NdO}(\mathrm{OH})$. $\mathrm{Nd}\left(\mathrm{CO}_{3}\right)_{2}{ }^{-}$was calculated to form at about $10^{-9}$ $\mathrm{M}$ at $\mathrm{pcH} 6$, increase to a constant value of $10^{-8} \mathrm{M}$ from $\mathrm{pcH} 7.2$ to 9.3, then decrease rapidly. It is not shown in Figure 3 as the lower limit is $10^{-7} \mathrm{M}$. Nd (OH) ${ }_{4}^{-}$was not included in the speciation in Figure 3 as the comparison of the trend with pcH of the experimental solubilities indicate that $\mathrm{Nd}(\mathrm{OH})_{4}^{-}$is not significant.

\section{Acknowledgements}

This research was carried out through the Waste Isolation Pilot Plant Project, was supported by the USDOE under Contract DEIC04-76DP0089 to Sandia National Laboratories and Subcontract 691734 to Florida State University. 


\section{REFERENCES}

1. Yamazaki, H., B. Lagerman, V. Symeopoulos, and G.R. Choppin. 1992. "Solubility of Uranyl in Brine," High Level Radioactive Waste Management, Proceedings of the Third International Conference, Las Vegas, NV, April 12-16, 1992. La Grange Park, IL: American Nuclear Society, Inc.; New York, NY: American Society of Civil Engineers. Vol. 2, 1607-1611.

3. Gran, G. 1952. "Determination of the Equivalence Point in Potentiometric Titrations. Part II," The Analyst. Vol. 77, no. $920,661-707$.

4. Marczenko, Z. 1986. Separation and Spectrophotometric Determination of Elements. New York, NY: Halsted Press.

5. Chen, J-F., F.I. Khalili, A.K. Mohammed, and G.R. Choppin. 1994. "Extraction and Spectrophotometric Determination of Nd(III), Th(IV) and U(VI) in Synthetic Brine Using Chlorophosphonazo III," Analytica Chimica Acta. Vol. 284, no. $3,593-597$.

6. Martell, A.E., and R.M. Smith. 1977. Critical stability Constants. Vol. 3: Other Organic Ligands. New York, NY: Plenum Publishing Corp.

7. Baes, C.F., Jr., and R.E. Mesmer. 1976. The Hydrolysis of Cations. New York, NY: John Wiley \& Sons.

8. Ingri, N., W. Kakolowicz, L.G. Sillen, and B. Warnqvist. 1967. "High-Speed Computers as a Supplement to Graphical Methods-V Haltafall, A General Program for Calculating the Composition of Equilibrium Mixtures," Talanta. Vol. 14, no. 11, 1261-1286.

9. Eriksson, G. 1979. "An Algorithm for the Computation of Aqueous Multicomponent, Multiphase Equilibria," Analytica Chimica Acta. Vol. 112, 375-383.

10. Grenthe, I., J. Fuger, R.J.M. Konings, R.J. Lemire, A.B. Muller, C. Nguyen-Trung, and H. Wanner. 1992. Chemical Thermodynamics of Uranium. Eds. H. Wanner and I. Forest. Chemical Thermodynamics Series Vol. 1. New York, NY: NorthHolland.

11. Ivanov-Emin, B.N., E.N. Siforova, V. Mel'yado Kampos, and E. Balestr Lafert. 1966. "Solubility of Some Lanthanide Hydroxides in Sodium Hydroxide Solutions," Russian Journal of Inorganic Chemistry. Vol. 11, no. 8, 1054-1055. 
This page intentionally left blank. 
Long Term Plutonium Solubility and Speciation Studies in a Synthetic Brine 
This page intentionally left blank. 


\title{
LBL-34896 \\ LONG TERM PLUTONIUM SOLUBILITY AND SPECLATION STUDIES \\ IN A SYNTHETIC BRINE
}

\begin{abstract}
Heino Nitsche, Kevin Roberts, Ruihua Xi, Traudel Prussin, Kevin Becraft, Ilham Al Mahamid Al Rifai, Herbert B. Silber, Scott A. Carpenter, Raymond C. Gatti

Earth Sciences Division, Lawrence Berkeley Laboratory, Berkeley, California 94720 USA
\end{abstract}

\section{Craig F. Novak}

Mail Stop 1320, Department 6119, Sandia National Laboratories, Albuquerque, New Mexico 87185-1320 USA

Keywords: Plutonium/Solubility/Speciation/Waste Isolation Pilot Plant (WIPP)/Brine

\begin{abstract}
The rate at which elements can be transported in groundwater systems is governed in part by the solubility of the element in the groundwater. This report documents plutonium solubility experiments, conducted over the past two years at the Lawrence Berkeley Laboratory, in a brine simulant relevant to the Waste Isolation Pilot Plant. Approximately 1 to $2.5 \mathrm{~mL}$ of five stock solutions containing single oxidation states of plutonium ( $\mathrm{Pu}(\mathrm{IV})$-polymer, $\mathrm{Pu}^{3+}, \mathrm{Pu}^{4+}, \mathrm{PuO}_{2}^{+}$, and $\mathrm{PuO}_{2}^{2+}$ ) were added to $75 \mathrm{~mL}$ of synthetic $\mathrm{H}-17$ Brine in five reaction vessels. Initial plutonium concentrations ranged from $1.3 \times 10^{-4}$ to $5.1 \times 10^{-4} \mathrm{M}$ (moles per liter) total plutonium. Because these initial concentrations were far above the plutonium solubility limit in $\mathrm{H}-17$ Brine, plutonium-containing solids precipitated. Aqueous plutonium concentrations were measured over time until steady-state was reached, requiring over 300 days in $\mathrm{H}-17$ Brine. Steady-state plutonium concentrations ranged from $3.0 \times 10^{-8}$ to $7.6 \times 10^{-7} \mathrm{M}$, and the predominant plutonium oxidation state in solution was $\mathrm{Pu}(\mathrm{VI})$. The solid phase from the initially $\mathrm{Pu}(\mathrm{IV})$ polymer experiment remained polymeric-Pu(IV). The solids that formed in the initially $\mathrm{Pu}^{3+}$ and $\mathrm{Pu}^{4+}$ experiments were crystalline yet remain unidentified. The solids that formed in the initially $\mathrm{PuO}_{2}^{+}$and $\mathrm{PuO}_{2}^{2+}$ experiments appear to be sodium plutonyl(V) carbonates.
\end{abstract}




\section{Introduction}

Understanding the behavior of dissolved plutonium in natural systems is important for assessing the performance of proposed nuclear waste repositories. Migration of dissolved plutonium depends upon the plutonium oxidation state and concentrations of groundwater constituents that can complex with the plutonium. In addition, the total dissolved plutonium concentration depends on the plutoniumbearing solid phase(s) that control solubility. Particularly for plutonium in brine systems, little experimental data exists for demonstrating either oxidation states or the solubility-controlling solids. This paper documents steady-state plutonium concentrations, oxidation state distributions, and solubility-controlling solids in a complex synthetic groundwater.

This solubility study was undertaken in support of the Waste Isolation Pilot Plant (WIPP), a U.S. Department of Energy facility intended to demonstrate the safe geologic disposal of defense-generated transuranic nuclear waste. The WIPP is located deep underground in a bedded salt formation in southeastern New Mexico. The little groundwater that exists in the WIPP vicinity range from seawater-like ( $\sim 0.8$ molal ionic strength) brines to highly concentrated ( $\sim 8$ molal) brines. ${ }^{1}$ The chemical behavior of actinides in a variety of groundwaters from near the WIPP Site is being examined to support WIPP solubility and retardation studies.

This paper documents solubility studies of ${ }^{239} \mathrm{Pu}$ in $\mathrm{H}-17$ Brine, a simulant of brine taken from near the WIPP Site. Plutonium in five different initial forms ( $\mathrm{Pu}(\mathrm{IV})$-polymer, $\mathrm{Pu}^{3+}, \mathrm{Pu}^{4+}, \mathrm{PuO}_{2}^{+}$, and $\mathrm{PuO}_{2}^{2+}$ ), was added to the brine in five separate reaction vessels, in sufficient quantity to ensure initial supersaturation with $\mathrm{Pu}$. The experiments were conducted under oxic conditions with a fixed carbon dioxide overpressure, and the nominal hydrogen ion concentration was controlled over the length of the experiments. Total dissolved concentrations of plutonium were monitored over time until steady-state conditions were established. Aqueous 
plutonium oxidation state distributions were determined several times during the experiments, and the solid phases were characterized.

\section{Experimental}

Reagent grade chemicals were used to make synthetic H-17 Brine, with the composition as listed in Table 1. The anhydrous salts were dried in an oven at $110^{\circ} \mathrm{C}$ for four hours before use. Salts were massed on a Galaxy 400 analytical balance that had been calibrated using an NIST standardized mass set. All salts except sodium bicarbonate were added to a $1 \mathrm{~L}$ class "A" volumetric flask, the flask was flushed with argon for $~ 10$ minutes, and freshly distilled, deionized water was added. All solids dissolved with stirring over night. The $\mathrm{NaHCO}_{3}$ was added immediately before saturating the water simulant with the $\mathrm{CO}_{2} / \mathrm{O}_{2} / \mathrm{Ar}$ gas mixture.

Because the concentration of total inorganic carbon (TIC) in solution can change in response to the carbon dioxide content of gas over the solution, special care was taken to preserve the intended TIC concentration of H-17 Brine. This was accomplished by equilibrating the solutions with gas mixtures of (2634 $\mathrm{CO}_{2}$. The gas mixtures also contained $(20.75 \pm 0.88) \%$ oxygen to provide an oxic environment, with the balance made up of argon.

We measured the brine $\mathrm{pH}$ during saturation with carbon dioxide with a Ross glass combination pH electrode (Orion Research Incorporated, Boston, MA) to establish an operational $\mathrm{pH}$ that could be routinely measured with a glass electrode. This is not the actual $\mathrm{p}\left[\mathrm{H}^{+}\right]$, or $\mathrm{pcH}$, of the brine, but rather an operational $\mathrm{pH}_{\mathrm{OP}}$ that we maintained during the solubility experiments. The electrode was calibrated with NIST traceable standard buffers of 7 and 10 before being placed into the $\mathrm{H}-17$ Brine. Figure 1 shows the change in the measured $\mathrm{pH}_{O P}$ during the saturation with the $\mathrm{CO}_{2} / \mathrm{O}_{2} / \mathrm{Ar}$ gas mixture. After eight hours of saturation with the gas mixture, the initial $\mathrm{pH}_{\mathrm{OP}}$ of 8.06 stabilized to $\mathrm{pH}_{\mathrm{OP}}=7.14$.

The ${ }^{239} \mathrm{Pu}$ stock solution was prepared by dissolving plutonium metal in $6 \mathrm{M}$ 
Table 1. Composition of H-17 Brine.

\begin{tabular}{|c|c|c|c|}
\hline & Molarity & $g / L$ & ppm \\
\hline $\mathrm{Ca}^{2+}$ & 0.0289 & 1.159 & 1159 \\
\hline $\mathrm{Mg}^{2+}$ & 0.0741 & 1.800 & 1800 \\
\hline $\mathrm{Na}^{+}$ & 2.397 & 55.113 & 55113 \\
\hline $\mathrm{K}^{+}$ & 0.0307 & 1.200 & 1200 \\
\hline $\mathrm{Cl}^{-}$ & 2.482 & 88.000 & 88000 \\
\hline $\mathrm{SO}_{4}{ }^{2-}$ & 0.0750 & 7.200 & 7200 \\
\hline $\mathrm{Br}$ & 0.00095 & 0.043 & 43 \\
\hline$B^{3+}$ & 0.00398 & 0.076 & 76 \\
\hline $\begin{array}{l}\text { Total Inorganic Carbon (TIC), } \\
\quad \text { as } \mathrm{HCO}_{3} \\
\mathrm{pH}=7.0\end{array}$ & 0.00082 & 0.050 & 50 \\
\hline $\begin{array}{l}\left.\mathrm{pCO}_{2(\mathrm{~g})}=10^{-2.56} \mathrm{ATM}\right) \\
\text { lonic Strength }=3.0 \mathrm{molal} \\
\text { Density }=1.10 \mathrm{~g} / \mathrm{cm}^{3}\end{array}$ & & & \\
\hline
\end{tabular}

Table 2. Steady-state solution $\mathrm{pH}$ values, plutonium concentrations, and Eh values in $\mathrm{H}-17$ Brine at $25^{\circ} \mathrm{C}$.

\begin{tabular}{lccc}
\hline $\begin{array}{c}\text { Initial Oxidation } \\
\text { State }\end{array}$ & $\mathrm{pH}$ & Concentration $(\mathrm{M})$ & $\begin{array}{c}\text { Eh (mV) vs. normal } \\
\text { hydrogen electrode }\end{array}$ \\
\hline $\mathrm{Pu}(\mathrm{IV})$-polymer & $7.15 \pm 0.05$ & $(2.97 \pm 1.02) \times 10^{-8}$ & $471 \pm 15$ \\
$\mathrm{Pu}(\mathrm{III})$ & $7.09 \pm 0.06$ & $(1.63 \pm 0.52) \times 10^{-7}$ & $435 \pm 15$ \\
$\mathrm{Pu}(\mathrm{IV})$ & $7.13 \pm 0.04$ & $(1.78 \pm 0.39) \times 10^{-7}$ & $490 \pm 15$ \\
$\mathrm{Pu}(\mathrm{V})$ & $7.09 \pm 0.08$ & $(3.66 \pm 0.85) \times 10^{-7}$ & $394 \pm 15$ \\
$\mathrm{Pu}(\mathrm{VI})$ & $7.08 \pm 0.09$ & $(7.64 \pm 2.31) \times 10^{-7}$ & $404 \pm 15$ \\
\hline
\end{tabular}




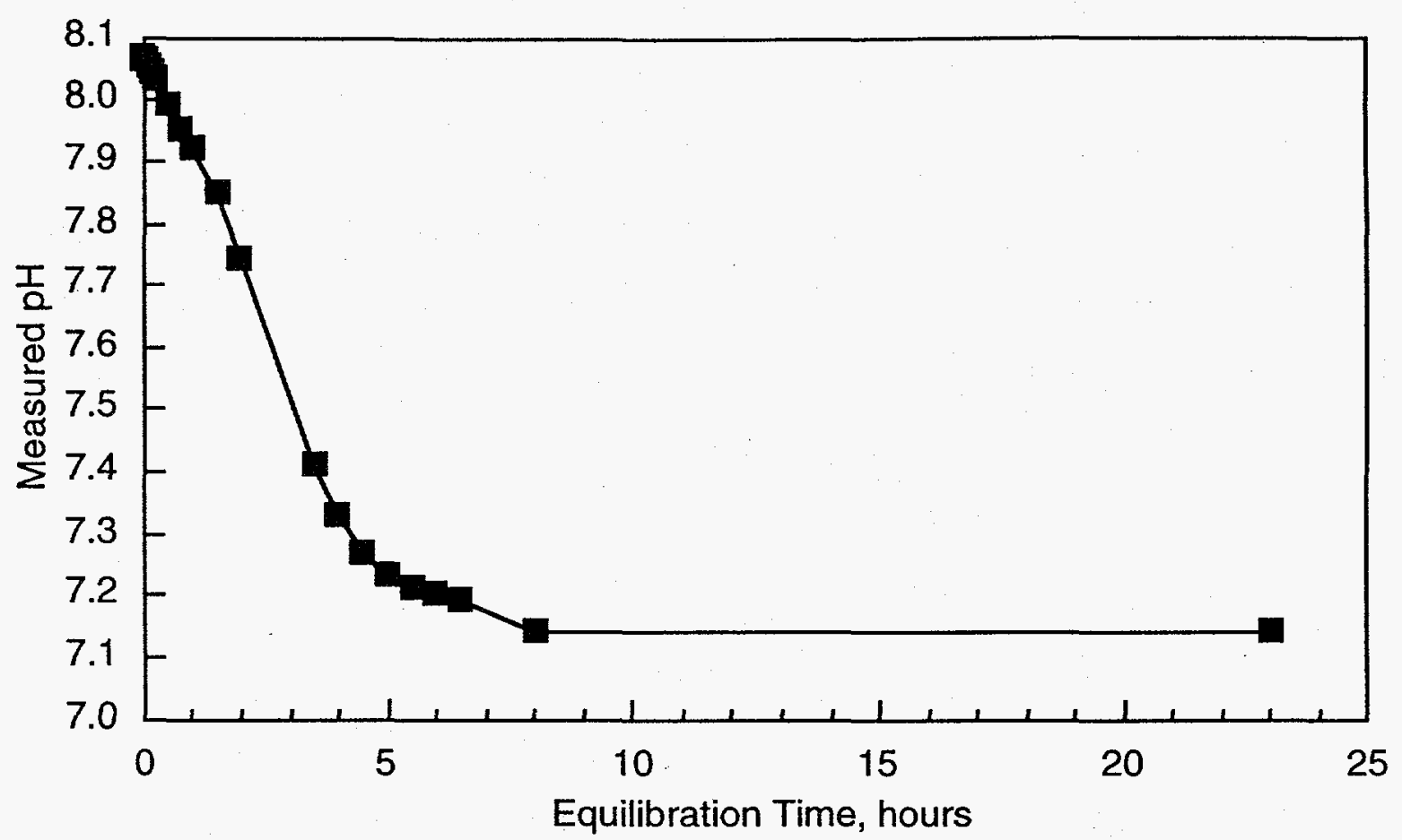

Figure 1. The operational $\mathrm{pH}$ measured by glass electrode in $\mathrm{H}-17$ Brine during saturation with a gas mixture of $2634 \pm 91 \mathrm{ppm} \mathrm{CO}_{2}, 20.75 \pm 0.88$ percent $\mathrm{O}_{2}$, with the balance made up of $\mathrm{Ar}$. 
hydrochloric acid. The solution was purified from possible metal contaminants by anion exchange chromatography. The oxidation states $\mathrm{Pu}(\mathrm{III}), \mathrm{Pu}(\mathrm{IV}), \mathrm{Pu}(\mathrm{V})$, and $\mathrm{Pu}(\mathrm{VI})$ were prepared by electrochemical adjustment of the plutonium stock solution. ${ }^{2-3}$ The presence of a single oxidation state was verified by absorption spectrophotometry. ${ }^{4}$ Before use, all stock solutions were filtered through $0.22 \mu \mathrm{m}$ polyvinylidene difluoride syringe filter units (Millipore Corporation, Bedford, MA) to remove possible suspended particles (e.g., dust or silica) that could sorb the plutonium to form pseudocolloids.

The $\mathrm{Pu}(\mathrm{IV})$-polymer was prepared by oxidizing a $\mathrm{Pu}(\mathrm{III})$ stock solution, $(\mathrm{pH}=2.5)$, at +1.1 volts versus a normal hydrogen electrode to $\mathrm{Pu}(\mathrm{IV})$ that immediately polymerized and settled out of solution.

The equilibration vessels were $90 \mathrm{~mL}$ Teflon perfluoralkoxy (PFA) cells (Savillex Corporation, Minnetonka, MN) with ports at the top to accommodate a $\mathrm{pH}$ electrode, a 1/16"-diameter Teflon line for the gas mixture, and an opening for withdrawing samples. Five individual reaction vessels were prepared to accommodate the five forms of plutonium stock solution to be studied.

Approximately 1 to $2.5 \mathrm{~mL}$ of each plutonium stock solution were added to 70 $\mathrm{mL} \mathrm{H-17}$ at the start of the experiment. The $\mathrm{pH}_{\mathrm{OP}}$ of the solutions was measured weekly and maintained at $7.14 \pm 0.10$. When required, the $\mathrm{pH}_{\mathrm{OP}}$ in the reaction vessels was adjusted with small amounts (usually between 5 and $50 \mu \mathrm{L}$ ) of $\mathrm{HCl}$ or $\mathrm{NaOH}(0.5-1 \mathrm{M})$. The electrodes were removed from the plutonium solutions after each $\mathrm{pH}_{\mathrm{OP}}$ measurement.

Quantitative separation of the aqueous phase from any solids or suspended particles is necessary for an accurate assessment of dissolved concentrations. For this process, we routinely used Centricon-30 (Amicon Corporation, Danvers, MA) centrifugal filters that contain a YM-type membrane with a calculated pore size of $4.1 \mathrm{~nm}$. Filters were tested for plutonium retention by filtering $500 \mu \mathrm{L}$ of the 
solubility solution and counting the filtrate. Another $500 \mu \mathrm{L}$ of solution was filtered through the same filter, and the second filtrate was assayed. This was repeated until a total volume of $2000 \mu \mathrm{L}$ had passed through the filter. Plutonium retention would be indicated by an increase in assayed concentration with each successive filtration step. Figure 2 shows that the filters did not retain the dissolved plutonium species present at the initiation of the five solubility experiments. Because plutonium concentrations and speciation may change over the course of the experiment, another test for filter retention was performed after $\sim 150$ days of reaction time, and again the results showed no significant retention of plutonium. Routine separations were performed after presaturating the filters with $500 \mu \mathrm{L}$ of solution.

Concentration measurements of the aqueous portions were made by $\gamma$-spectroscopy with a low-energy germanium counting system of Lawrence Berkeley Laboratory design, or with a liquid scintillation counter (Pharmacia LKB Nuclear Incorporated, Gaithersburg, MD, Model Rackbeta 1219). With the germanium counter, plutonium was analyzed for the uranium $L$ x-rays resulting from the $\alpha$-decay of the plutonium. Possible contributions to the $L$ x-rays from the decays of other radionuclides, also present in small amounts, were corrected by subtraction. ${ }^{5}$ The liquid scintillation counter (LSC) can discriminate between possible $\beta$-radiation and the plutonium $\alpha$-radiation. The LSC was calibrated with plutonium standards of similar chemical compositions.

The oxidation state of plutonium is one of the most important controlling factors for solubility. Although each experiment started with a single oxidation state, the oxidation states can and, in general, do change during solubility experiments. Unfortunately, the steady-state plutonium concentrations in $\mathrm{H}-17$ Brine were below the detection limit of conventional methods such as absorption spectrophotometry, so a series of organic extractions was used as an indirect method 


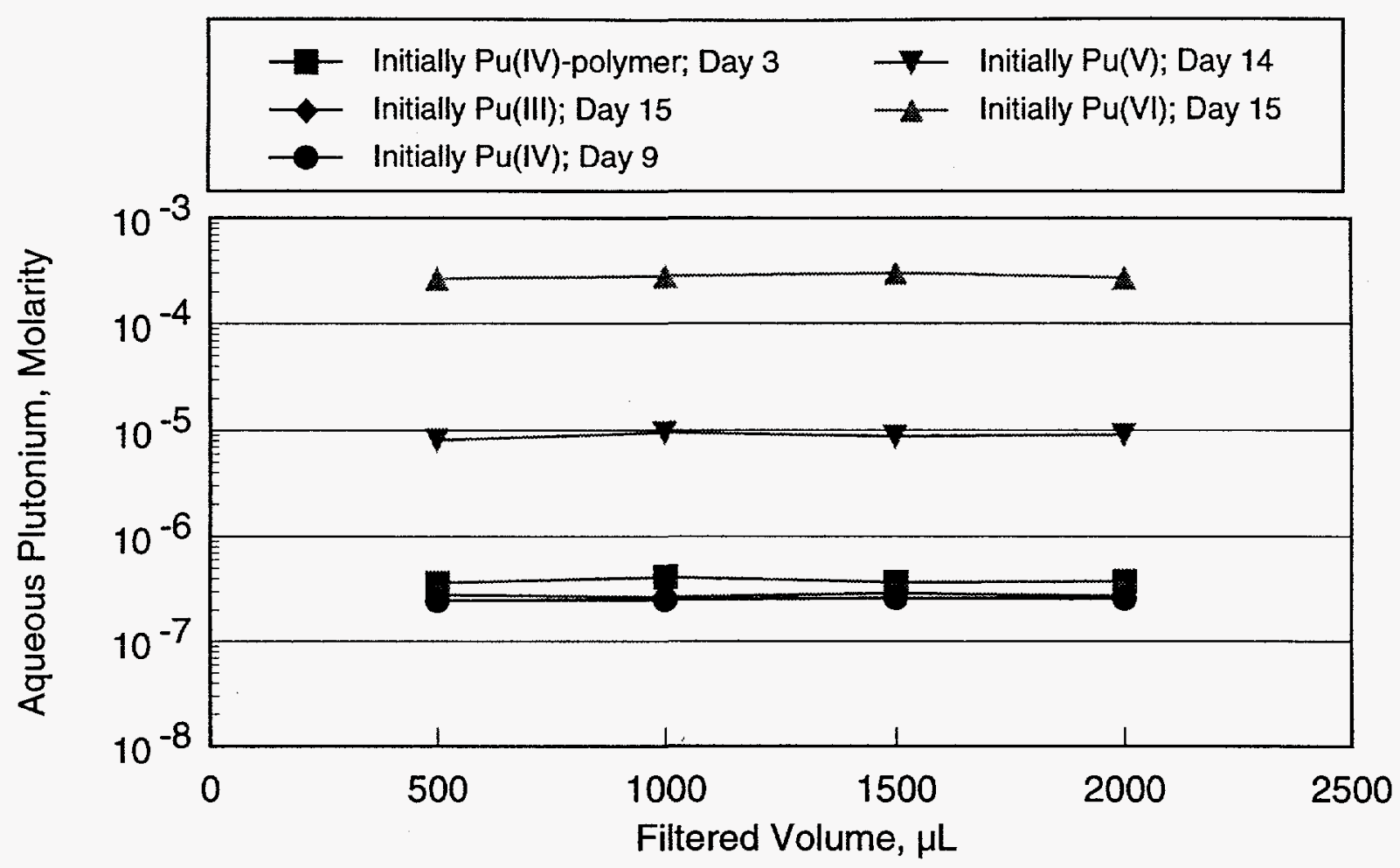

Figure 2. Results of filtration experiments with Centricon-30 filters. The lack of change in concentrations indicates there was no significant retention of plutonium on the filters upon initiating the experiments. 
for determining the distribution of the aqueous plutonium among its oxidation states. Table 3 lists the methods that we used. The method is based upon an earlier scheme, ${ }^{6}$ but for these solubility experiments we replaced thenoyltrifluoroacetone (TTA) with 1-phenyl-3-methyl-4-benzoy-pyrazol-5-one $(\mathrm{PMBP})^{7}$ because PMBP was more efficient as an extractant and was more resistant to decomposition by oxidants such as dichromate. All extractions were successfully tested on known oxidation states of plutonium in H-17 Brine. For the solubility experiments, each of the four separations was carried out independently to minimize the potential for changing the steady state distribution.

The oxidation potential, Eh, of each solution was measured at steady state with a platinum electrode versus a $\mathrm{Ag} / \mathrm{AgCl} /$ saturated $\mathrm{NaCl}$ reference. The platinum electrode was cleaned with $6 \mathrm{M}$ nitric acid before and after each measurement. The electrode setup was checked with "Zobell's Solution" before and after each measurement. ${ }^{8-9}$

The solids were analyzed by $x$-ray powder diffraction. A few micrograms of each actinide precipitate were placed in a $0.33-\mathrm{mm}$ diameter quartz capillary tube. The tube was mounted in an 11.46-cm diameter Debye-Scherrer camera and then irradiated with x-rays from a Norelco III x-ray generator (Philips Electronics, Inc.). Copper $\mathrm{K}_{\alpha}$ radiation filtered through nickel was used.

\section{Results and Discussion}

\section{Solubility}

The experimental results for dissolved plutonium concentrations are shown in Figure 3. The steady-state $\mathrm{pH}$ values, plutonium concentrations, and Eh values are given in Table 2.

The dissolved concentrations in the initially $\mathrm{Pu}(\mathrm{III}), \mathrm{Pu}(\mathrm{IV}), \mathrm{Pu}(\mathrm{V})$, and $\mathrm{Pu}$ (IV)-polymer experiments dropped by two to three orders of magnitude within about 50 days. After that time, the concentrations changed no more than an order 
Table 3. Methods Used for Determining Plutonium Oxidation States in H-17 Brine.

\begin{tabular}{|c|c|c|}
\hline \multirow[t]{2}{*}{ Method } & \multicolumn{2}{|c|}{ Oxidation State Distribution } \\
\hline & Organic Phase & Aqueous Phase \\
\hline $\begin{array}{l}\text { PMBP Extraction at } \\
\mathrm{pH}=0\end{array}$ & $(+4)$ & $(+3,+5,+6, p)^{\mathrm{a}}$ \\
\hline $\begin{array}{l}\text { PMBP Extraction at } \\
\mathrm{pH}=0 \mathrm{w} / \mathrm{Cr}_{2} \mathrm{O}_{7}^{=}\end{array}$ & $(+3,+4)$ & $(+5,+6, p)^{a}$ \\
\hline $\begin{array}{l}\text { HDEHP Extraction } \\
\text { at } \mathrm{pH}=0\end{array}$ & $(+4,+6)$ & $(+3,+5, p)^{a}$ \\
\hline $\begin{array}{l}\text { HDEHP Extraction } \\
\text { at } \mathrm{pH}=0 \mathrm{w} / \mathrm{Cr}_{2} \mathrm{O}_{7}^{=}\end{array}$ & $(+3,+4,+5,+6)$ & $(p)^{a}$ \\
\hline
\end{tabular}

(a) $\mathrm{p}=\mathrm{Pu}$ (IV) polymer 


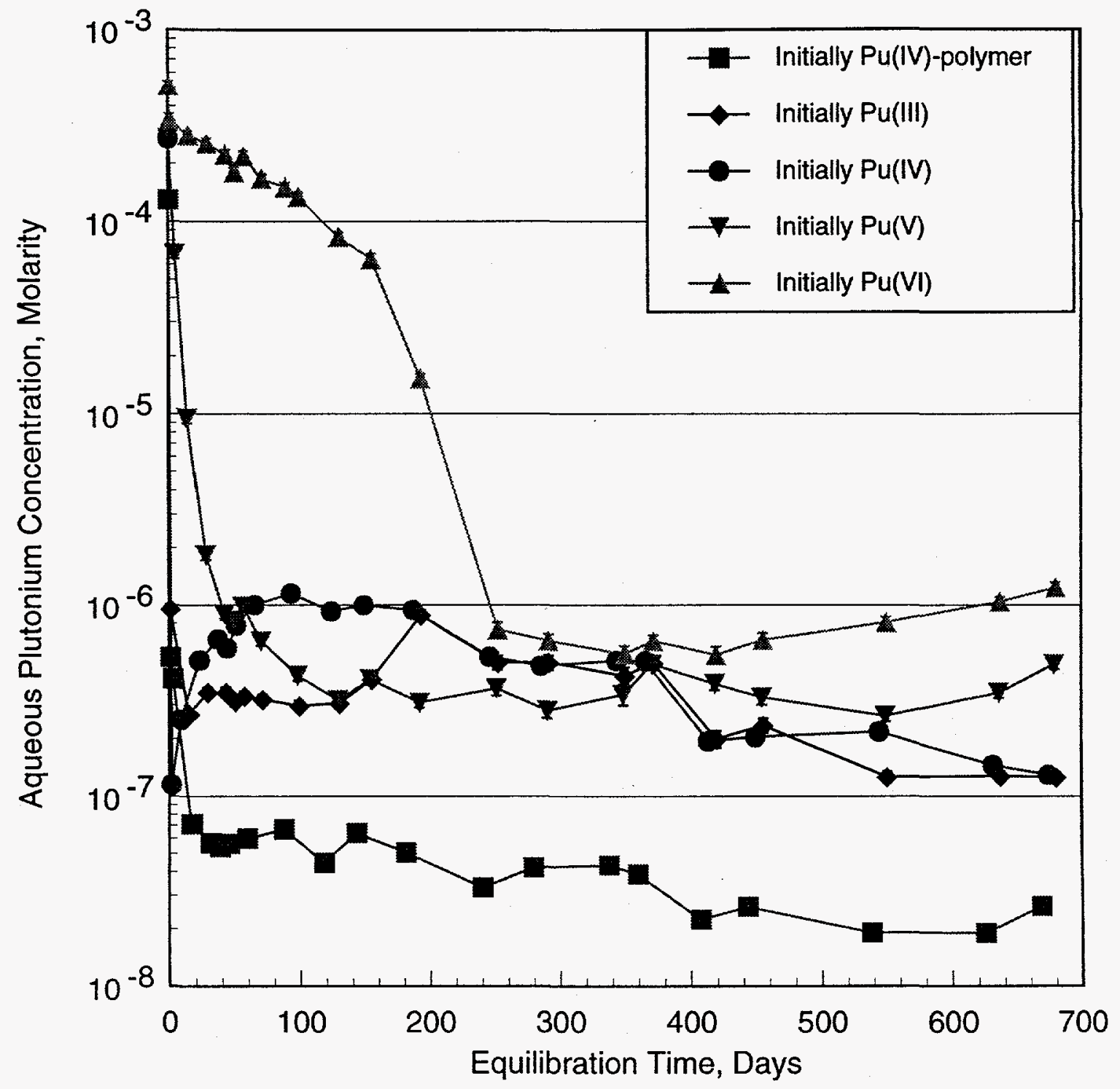

Figure 3. Total dissolved plutonium concentrations versus time for five initial forms of aqueous plutonium in $\mathrm{H}-17$ Brine. 
of magnitude over 600 additional days. The initially $\mathrm{Pu}(\mathrm{VI})$ experiment behaved very differently, remaining significantly higher in its aqueous plutonium concentration for about 250 days before a similar drop in aqueous plutonium occurred. After approximately 350 days of reaction time, the concentrations for the initially $\mathrm{Pu}(\mathrm{III})$, (IV), (V), and (VI) experiments were all within a factor of 1.6 of one another, their average being $\sim 5 \times 10^{-7} \mathrm{M}$. The plutonium concentration in the initially $\mathrm{Pu}(\mathrm{IV})$-polymer experiment was an order of magnitude lower, $4.3 \times 10^{-8} \mathrm{M}$. Note that true steady state conditions in H-17 Brine were not reached even after nearly 700 days of equilibration time.

Steady-state concentrations listed in Table 2 are the averages of the individual concentration measurements from days 279 to 668 for the initially $\mathrm{Pu}(\mathrm{IV})$-polymer experiment, from 419 to 680 for the initially $\mathrm{Pu}(\mathrm{III})$ experiment, from 413 to 674 for the initially $\mathrm{Pu}(\mathrm{IV})$ experiment, from 290 to 679 for the initially $\mathrm{Pu}(\mathrm{V})$ experiment, and from 252 to 680 for the initially $\mathrm{Pu}(\mathrm{VI})$ experiment. The error listed with each average concentration is the standard deviation.

The five H-17 experiments were oxic, with measured Eh values from 400 to $500 \mathrm{mV}$ versus a normal hydrogen electrode. These measurements are very general and are of limited value because they represent a combination of many redox reactions in each of these solubility experiments. Only with elaborate chemical modeling can these overall potentials be explained.

\section{Oxidation State Determinations}

Results of oxidation state determinations performed at steady state in the solubility experiments are shown in Figure 4. These determinations were performed after approximately 350 days of reaction time and after steady-state conditions were met. The results show $\mathrm{Pu}(\mathrm{VI})$ as the predominant oxidation state in solution at steady state regardless of the oxidation state used at the start of the experiments. We also found smaller, but significant, amounts of $\mathrm{Pu}(\mathrm{V})$ in some of 


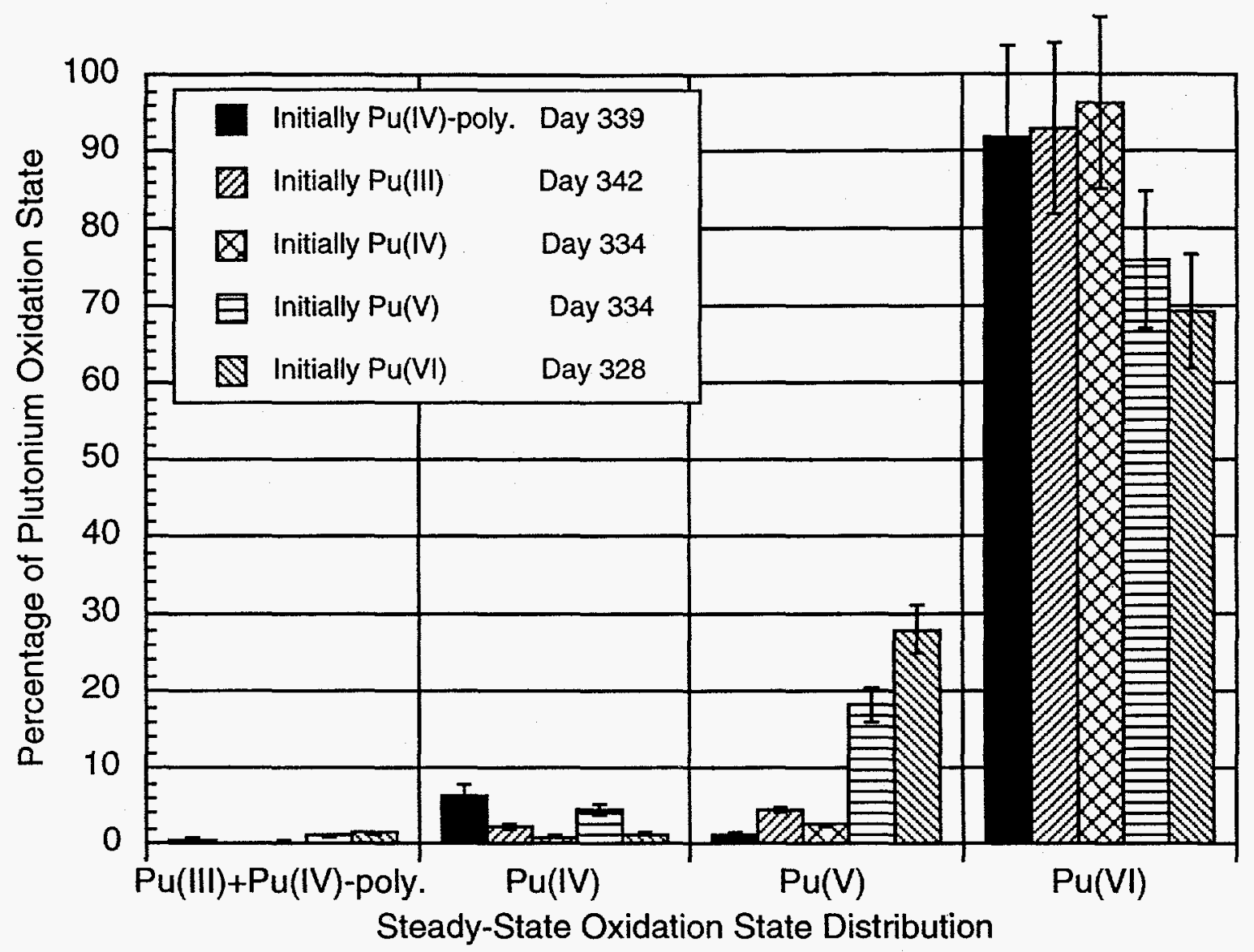

Figure 4. Plutonium oxidation state distributions in five different $\mathrm{H}-17$ Brine experiments at steady-state conditions. 
the solutions. These observed valence distributions cannot be explained by disproportionation equilibria and complex stabilization. 10 It is possible that reaction products formed by $\alpha$-radiolysis of $\mathrm{H}-17$ Brine may cause the predominance of high oxidation states in the plutonium solutions. We confirmed the oxidation state results shown in Figure 4 later in the experiments, using the same separation scheme.

\section{Identification And Characterization Of Solids}

The solids formed in the $\mathrm{H}-17$ oversaturation experiments were examined after approximately 600 days of reaction time. From visual observations, it appeared that the solids formed in the initially $\mathrm{Pu}(\mathrm{IV})$-polymer, $\mathrm{Pu}(\mathrm{III})$, and $\mathrm{Pu}(\mathrm{IV})$ experiments were very much the same. They each resembled the green polymericplutonium(IV) used to start the initially $\mathrm{Pu}(\mathrm{IV})$-polymer solubility experiment. The crystalline component in the solids that formed in the initially $\mathrm{Pu}(\mathrm{V})$ and $\mathrm{Pu}(\mathrm{VI})$ experiments also appeared to be the same; they were both a tan, crystalline powder.

To determine if the green solids we obtained were polymeric-plutonium(IV), we tried dissolving very small portions of the solids in $1 \mathrm{M} \mathrm{HCl}$. We then filtered the solutions through Amicon Centriprep-30 centrifugal filters (4.1 nm). We assayed the acidified plutonium solutions before and after filtration to determine the relative amount of solid that dissolved in $1 \mathrm{M} \mathrm{HCl}$. Crystalline solids like plutonium hydroxides or plutonium carbonates will immediately dissolve in $1 \mathrm{M}$ $\mathrm{HCl}$; whereas, polymeric-plutonium(IV) will not dissolve. The filtration will remove any undissolved solids larger than $4.1 \mathrm{~nm}$ from the solution. We expected that for the initially $\mathrm{Pu}(\mathrm{IV})$-polymer experiment, very little solid, if any, would dissolve and/or pass through the filter. Only 14 percent of the acidified plutonium solid passed through the filter. This may have been a crystalline component or possibly carbonate complexed plutonium on the surface of the polymeric-plutonium(IV) that did dissolve. It also may have been polymeric-plutonium(IV) that was smaller than 
$4.1 \mathrm{~nm}$ and passed through the filter without dissolving. In either case, eighty-six percent of the solid did not dissolve and is most likely $\mathrm{Pu}(\mathrm{IV})$-polymer.

For the initially $\mathrm{Pu}(\mathrm{III})$ and $\mathrm{Pu}(\mathrm{IV})$ experiments, 76 and 73 percent of the respective solids dissolved and/or passed through the filter. These results show that approximately three quarters of the plutonium solids that formed in these two experiments may not be polymeric-plutonium(IV). If this component has a higher solubility than polymeric-plutonium(IV), it would explain why the steady-state aqueous plutonium concentrations in the initially $\mathrm{Pu}(\mathrm{III})$ and $\mathrm{Pu}(\mathrm{IV})$ experiments are an order of magnitude higher than that found in the initially $\mathrm{Pu}(\mathrm{IV})$-polymer experiment.

Ninety-three and 100 percent of the respective solids from the initially $\mathrm{Pu}(\mathrm{V})$ and $\mathrm{Pu}(\mathrm{VI})$ experiments dissolved and/or passed through the filters. These solids are believed to have dissolved because they effervesced upon contact with acid. This also implies that these plutonium solids contained carbonate. The seven percent of the solid from the initially $\mathrm{Pu}(\mathrm{V})$ experiment that did not dissolve or pass through the filter is probably polymeric-plutonium(IV), which explains the small amount of the green solid we found with the crystalline component.

To further characterize these plutonium solids, we isolated small portions of the plutonium solids for x-ray powder diffraction. Microgram amounts of the dried plutonium solids were encapsulated in quartz capillaries and then analyzed by $x$-ray powder diffraction. The d-spacings and relative intensities for the powder patterns of the dried plutonium solids are listed in Table 4. We also washed another portion of the solids with distilled water followed by ethanol to try removing any salts, such as $\mathrm{NaCl}$, that may have coprecipitated from the brine. Although washing may perturb the crystal structure of the plutonium solids, the respective powder patterns show little change between washed and unwashed samples.

We compared the x-ray powder diffraction patterns with reference patterns 
Table 4. X-ray powder diffraction patterns for the unwashed solids obtained in the plutonium/H-17 oversaturation experiments.

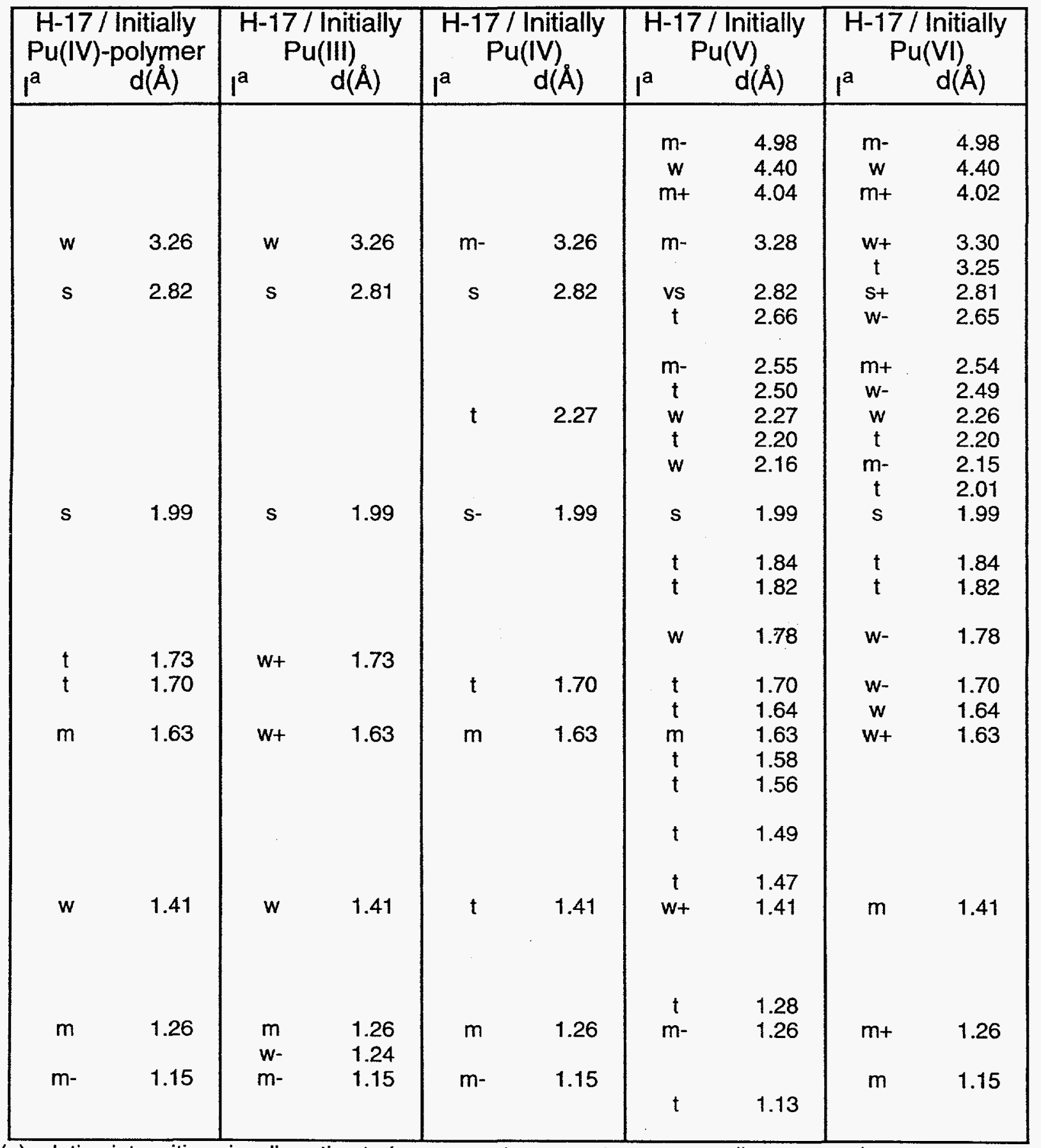

(a) relative intensities visually estimated: $v s=$ very strong, $s=s t r o n g, ~ m=$ medium, $w=w e a k, t=$ trace. 
published in the literature to assign the lines. They were compared to patterns of crystalline $\mathrm{PuO}_{2},{ }^{11} \mathrm{PuO}_{3} \bullet 0.8 \mathrm{H}_{2} \mathrm{O},{ }^{12} \mathrm{KPuO}_{2} \mathrm{CO}_{3},{ }^{13} \mathrm{NH}_{4} \mathrm{PuO}_{2} \mathrm{CO}_{3},{ }^{13}$ and $\mathrm{PuO}_{2} \mathrm{CO}_{3} \cdot 14$

The three solids from the initially $\mathrm{Pu}(\mathrm{IV})$-polymer, $\mathrm{Pu}(\mathrm{III})$, and $\mathrm{Pu}(\mathrm{IV})$ dissolved concentration experiments in $\mathrm{H}-17$ Brine produced powder patterns with the same diffraction lines. Because very little of the solid produced in the initially $\mathrm{Pu}(\mathrm{IV})$-polymer experiment dissolved in acid, we conclude that the solid taken from the end of the experiment was composed mostly of $\mathrm{Pu}(\mathrm{IV})$-polymer. However, most of the solids produced in the initially $\mathrm{Pu}$ (III) and $\mathrm{Pu}(\mathrm{IV})$ experiments did dissolve in $1 \mathrm{M} \mathrm{HCl}$ and/or pass through the filter, so we conclude that these solid phases are possibly crystalline or $\mathrm{Pu}(\mathrm{IV})$-polymer smaller than $4.1 \mathrm{~nm}$. The x-ray powder diffraction patterns did not match any of the published reference patterns for plutonium compounds. We indexed the d-spacings to determine the lattice structure and found that a cubic lattice structure, like that of sodium chloride, for example, will produce these diffraction lines.

The crystalline precipitates from the $\mathrm{H}-17$ Brine experiments containing initially $\mathrm{PuO}_{2}^{+}$and $\mathrm{PuO}_{2}^{2+}$ had identical x-ray powder diffraction patterns, and this pattern compared well with patterns of $\mathrm{KPuO}_{2} \mathrm{CO}_{3}{ }^{13}$ and $\mathrm{NH}_{4} \mathrm{PuO}_{2} \mathrm{CO}_{3} .{ }^{13}$ However, considering that the sodium content in $\mathrm{H}-17$ Brine is nearly 80 times greater than the potassium content, we conclude that these solids are more likely sodium plutonyl(V) carbonates, $\mathrm{NaPuO}_{2} \mathrm{CO}_{3}(\mathrm{~s})$. No reference powder pattern was found for $\mathrm{NaPuO}_{2} \mathrm{CO}_{3}(\mathrm{~s})$, but the $\mathrm{NaPuO}_{2} \mathrm{CO}_{3}$ unit cell lattice structure was reported in comparison with the analogous potassium and ammonium solids. ${ }^{15}$ Precipitation of plutonyl(V) with carbonate results in hexagonal, orthorhombic, or monoclinic solids depending on the size of the accompanying cation involved. Larger accompanying cations, like ammonium, favor the formation of a hexagonal crystal lattice. The potassium cation forms an orthorhombic solid; whereas, the 
smaller alkali cation, sodium, precipitates the plutonyl(V) carbonate as a monoclinic solid. We indexed the powder pattern from the solid obtained in the initially $\mathrm{Pu}(\mathrm{V})$ and $\mathrm{Pu}(\mathrm{VI})$ oversaturation experiments with hexagonal, orthorhombic, and monoclinic crystal lattices. Only a monoclinic crystal lattice was able to produce calculated d-spacings that agreed with the experimental powder patterns.

\section{Conclusions}

These studies demonstrate a successful methodology for accurately determining the solubility or dissolved concentrations of plutonium in brines. The measurement of dissolved concentrations in solubility studies is obviously not a "quick and dirty" process. The experiments documented here required on the order of three to four months to reach an approximate steady state; true equilibrium was not achieved even after almost two years of reaction time.

We determined that the steady-state dissolved plutonium concentrations ranged from $2 \times 10^{-7}$ to $8 \times 10^{-7}$ moles per liter for the $\mathrm{H}-17$ Brine experiments started with initially $\mathrm{Pu}(\mathrm{III}), \mathrm{Pu}(\mathrm{IV}), \mathrm{Pu}(\mathrm{V})$, and $\mathrm{Pu}(\mathrm{VI})$. The steady-state dissolved plutonium concentration in the initially $\mathrm{Pu}(\mathrm{IV})$-polymer experiment was an order of magnitude lower at $3 \times 10^{-8}$ moles per liter.

The oxidation state determinations were conclusive in that we were able to determine the relative amounts of all four of the primary plutonium oxidation states in each of the experiments. We found the dominant oxidation state for the soluble plutonium in all five of the experiments to be $\mathrm{Pu}(\mathrm{VI})(70-90 \%)$. The remainder of the soluble plutonium was composed of mostly $\mathrm{Pu}(\mathrm{V})$ with only traces of $\mathrm{Pu}(\mathrm{IV})$ and $\mathrm{Pu}(\mathrm{III})$ being present.

As for the solid phases, we found that for the initially $\mathrm{Pu}(\mathrm{IV})$-polymer experiment the steady-state solid appears to be primarily polymeric-plutonium(IV) with a small amount of an unidentified component. The solids produced in the initially $\mathrm{Pu}(\mathrm{III})$ and $\mathrm{Pu}(\mathrm{IV})$ experiments are primarily an unidentified precipitate 
with some polymeric-plutonium(IV). The solids produced in the initially $\mathrm{Pu}(\mathrm{V})$ and $\mathrm{Pu}(\mathrm{VI})$ experiments dissolved easily in acid, effervescing as they dissolved. Both of the powder patterns closely match the published patterns for the potassium and ammonium plutonyl(V) carbonates, but they could only be indexed with a monoclinic crystal lattice, suggesting that these two solids are sodium plutonyl(V) carbonates.

\section{Acknowledgments}

This work was performed at the Lawrence Berkeley Laboratory for Sandia National Laboratories under Contract No. 40-2516. The Lawrence Berkeley Laboratory is operated by the University of California for the U.S. Department of Energy under Contract DE-AC-03-76SF00098. 


\section{REFERENCES}

1. Novak, C.F. 1992. An Evaluation of Radionuclide Batch Sorption Data on Culebra Dolomite for Aqueous Compositions Relevant to the Human Intrusion Scenario for the Waste Isolation Pilot Plant. SAND91-1299. Albuquerque, NM: Sandia National Laboratories.

2. Cohen, D. 1961a. "Electrochemical Studies of Plutonium Ions in Perchloric Acid Solution," Journal of Inorganic and Nuclear Chemistry. Vol. 18, 207-216.

3. Newton, T.W., D.E. Hobart, and P.D. Palmer. 1986. The Preparation and stability of pure oxidation states of Neptunium, Plutonium, and Americium. LA-UR-86-967. Los Alamos, NM: Los Alamos National Laboratory, Isotope and Nuclear Chemistry Division. (Copy on file at the Sandia WIPP Central Files, Sandia National Laboratories, Albuquerque, NM.)

4. Cohen, D. 1961b. "The Absorption Spectra of Plutonium Ions in Perchloric Acid Solutions," Journal of Inorganic and Nuclear Chemistry. Vol. 18, 211-228.

5. Nitsche, H., R.C. Gatti, and S.C. Lee. 1991. "Low-level Determination of Plutonium by Gamma and L X-ray Spectroscopy," Journal of Radioanalytical and Nuclear Chemistry. Vol. 161, no. $2,401-411$.

6. Nitsche, H., S.C. Lee, and R.C. Gatti. 1988. "Determination of Plutonium oxidation States at Trace Levels Pertinent to Nuclear Waste Disposal," Journal of Radioanalytical and Nuclear Chemistry, Articles. Vol. 124, no. 1, 171-185.

7. Zolotov, Y.A., M.K. Chmutova, and P.N. Palei. 1966. "Solvent Extraction of Chelate Compounds of Plutonium(IV) with 1phenyl-3-methyl-4-benzoylpyrazolone-5," Zhurnal Analitcheskoi Khimii. Vol. 21, no. 10, 1217-1222.

8. Garrels, R.M. 1960. Mineral Equilibria at Low Temperature and Pressure. New York, NY: Harper and Row.

9. Langmuir, D. 1971. "Eh-Ph Determination," Procedures in Sedimentary Petrology. Ed. R.E. Carver. New York, NY: WileyInterscience. 597-635.

10. Silver, G.L. 1972. "Suggestion for the Determination of Plutonium Valencies in Aqueous Solutions," Radiochemical and Radioanalytical Letters. Vol. 9, no. 5-6, 315-320.

11. Mooney, R.C.L., and W.H. Zachariasen. 1949. "Crystal Structure Studies of Oxides of Plutonium," The Transuranium Elements. Research Papers. Eds. G.T. Seaborg, J.J. Katz, and W.M. Manning. New York, NY: McGraw-Hill Book Company, Inc. Part II, $1442-1447$. 
12. Bagnall, K.W., and J.B. Laidler. 1964. "Neptunium and Plutonium Trioxide Hydrates, "Journal of the Chemical Society. August 1964, 2693-2696.

13. Ellinger, F.H., and W.H. Zachariasen. 1954. "The Crystal Structure of $\mathrm{KPuO}_{2} \mathrm{CO}_{3}$ and $\mathrm{RbAmO}_{2} \mathrm{CO}_{3}$," The Journal of Physical Chemistry. Vol. 58, 405-408.

14. Navratil, J.D., and H.L. Bramlet. 1973. "Preparation and Characterization of Plutonyl(VI) Carbonate," Journal of Inorganic and Nuclear Chemistry. Vol. 35, no. 1, 157-163.

15. Nigon, J.P., R.A. Penneman, E. Staritzky, T.K. Keenan, and I.B. Asprey. 1954. "Alkali Carbonates of $\mathrm{Np}(\mathrm{V}), \mathrm{Pu}(\mathrm{V})$ and Am(V)," Journal of Physical Chemistry. Vol. 58, 403-406. 
This page intentionally left blank. 
Solubility of $\mathrm{NaNd}\left(\mathrm{CO}_{3}\right)_{2} \bullet 6 \mathrm{H}_{2} \mathrm{O}(\mathrm{c})$ in Concentrated Sodium Carbonate and Sodium Bicarbonate Solutions 
This page intentionally left blank. 


\title{
SOLUBILITY OF NaNd $\left(\mathrm{CO}_{3}\right)_{2} \cdot 6 \mathrm{H}_{2} \mathrm{O}$ (c) IN CONCENTRATED SODIUM CARBONATE AND SODIUM BICARBONATE SOLUTIONS
}

Linfeng Rao, Dhanpat Rai, Andrew R. Felmy, and Robert W. Fulton Pacific Northwest Laboratory ${ }^{a}$

Richland, Washington 99352

\begin{abstract}
The stable solid phases and carbonate complexes of neodymium in concentrated carbonate and bicarbonate solutions were identified by equilibration of $\mathrm{Nd}_{2}\left(\mathrm{CO}_{3}\right)_{3} \cdot \mathrm{xH}_{2} \mathrm{O}$ or $\mathrm{NaNd}\left(\mathrm{CO}_{3}\right)_{2} \cdot 6 \mathrm{H}_{2} \mathrm{O}$ with sodium carbonate $(0.1$ to $2.0 \mathrm{M}$ ) and sodium bicarbonate solutions $(0.1$ to $1.0 \mathrm{M})$ for a period of more than 100 days. In all the experiments, $\mathrm{NaNd}\left(\mathrm{CO}_{3}\right)_{2} \cdot 6 \mathrm{H}_{2} \mathrm{O}$ was found to be the final equilibrium solid phase. A thermodynamic model, based on the Pitzer's specific ion-interaction approach, was developed to interpret the solubility data. In this model, the solubility data of $\mathrm{NaNd}\left(\mathrm{CO}_{3}\right)_{2} \cdot 6 \mathrm{H}_{2} \mathrm{O}(\mathrm{c})$ were explained by assuming the formation of $\mathrm{NdCO}_{3}^{+}, \mathrm{Nd}\left(\mathrm{CO}_{3}\right)_{2}^{-}$, and $\mathrm{Nd}\left(\mathrm{CO}_{3}\right)_{3}{ }^{3-}$ species. Ion interaction parameters for $\mathrm{Na}^{+}-\mathrm{Nd}\left(\mathrm{CO}_{3}\right)_{2}{ }^{-}$and $\mathrm{Na}^{+}-\mathrm{Nd}\left(\mathrm{CO}_{3}\right)_{3}{ }^{3-}$ were developed as required to fit the data in concentrated solutions. The logarithm of the $\mathrm{NaNd}\left(\mathrm{CO}_{3}\right)_{2} \cdot 6 \mathrm{H}_{2} \mathrm{O}$ solubility product $\left(\mathrm{NaNd}\left(\mathrm{CO}_{3}\right)_{2} \cdot 6 \mathrm{H}_{2} \mathrm{O}(\mathrm{c})=\mathrm{Na}^{+}+\mathrm{Nd}^{3+}+2 \mathrm{CO}_{3}{ }^{2-}+6 \mathrm{H}_{2} \mathrm{O}\right)$ was

aPacific Northwest Laboratory is operated for the U.S. Department of Energy by Battelle Memorial Institute under Contract DE-AC06-76RLO 1830.
\end{abstract}


calculated to be -21.40 . Based on the model calculations. $\mathrm{Nd}\left(\mathrm{CO}_{3}\right)_{3}{ }^{3-}$ was the predominant aqueous neodymium species in 0.1 to $2 \mathrm{M}$ sodium carbonate solutions, while both $\mathrm{Nd}\left(\mathrm{CO}_{3}\right)_{2}{ }^{-}$and $\mathrm{Nd}\left(\mathrm{CO}_{3}\right)_{3}{ }^{3-}$ were important neodymium species in 0.1 to $1 \mathrm{M}$ sodium bicarbonate solutions. This model also provided satisfactory interpretation of the solubility data of the analogous Am(III) system in less concentrated carbonate and bicarbonate solutions.

Key words

Neodymium/ Carbonate/ Bicarbonate/ Solubility/ Ion-interaction 


\section{Introduction}

Thermodynamic data on stable solid phases, solubility limits, and aqueous speciation are essential in understanding and predicting the transport of radionuclides in aqueous systems. The solid-liquid phase equilibria of trivalent actinides and lanthanides in carbonate-bicarbonate systems have been studied because 1) some natural aqueous systems have high $\mathrm{CO}_{2}$ partial pressures $(0.03$ to $10 \%)[1,2]$, which result in high aqueous concentrations of carbonate and bicarbonate, and 2) these cations form strong aqueous carbonato complexes under certain conditions $[3,4,5,6]$, which could increase the aqueous concentrations of these cations and significantly enhance their mobility.

The available thermodynamic data for carbonate systems involving trivalent actinides and lanthanides are highly diverse and complex. Silva and Nitsche [7] determined $\mathrm{AmOH}\left(\mathrm{CO}_{3}\right)(\mathrm{c})$ to be the stable phase in solutions equilibrated with $0.03 \% \mathrm{CO}_{2}$ (pH about 6). Bernkopf and $\mathrm{Kim}$ [5] reported that $\mathrm{AmOH}\left(\mathrm{CO}_{3}\right)(\mathrm{c})$ was the thermodynamically stable solid phase in solutions with total carbonate concentrations of at least $0.1 \mathrm{M}$. However, Shiloh et al. [6] found $\mathrm{Am}_{2}\left(\mathrm{CO}_{3}\right)_{3}(\mathrm{~s})$ to be the stable phase in 0.1 to $0.6 \mathrm{M} \mathrm{K}_{2} \mathrm{CO}_{3}$. Firsching and Mohammadzadel [8] determined the solubility of rare earth carbonates $\left(\mathrm{Ln}_{2}\left(\mathrm{CO}_{3}\right)_{3}, \mathrm{Ln}=\right.$ lanthanides $)$ in $\mathrm{H}_{2} \mathrm{O}$ with a $\mathrm{pH}$ range of 4.6 to 6.2 and reported $\mathrm{pK}_{\mathrm{sp}}$ values ranging from 28.25 to 35.45 . Their data showed an abnormally high solubility for $\mathrm{Er}_{2}\left(\mathrm{CO}_{3}\right)_{3}$ relative to its neighboring rare earth analogs. This abnormality remains unexplained and questionable. Recently, Meinrath and co-workers $[9,10,11]$ and Runde et al. [12] determined conditional solubility products of different $\mathrm{Am}(\mathrm{III})$ and $\mathrm{Nd}(\mathrm{III})$ carbonates in 0.1 and $0.3 \mathrm{M} \mathrm{NaClO}_{4}$ solutions maintained at different $\mathrm{CO}_{2}$ partial pressures 
$(0.03$ to $100 \%)$ and $\mathrm{pH}$ values (4 to 9$)$. In these systems, either $\mathrm{MOH}\left(\mathrm{CO}_{3}\right)(\mathrm{s})$ or $\mathrm{M}_{2}\left(\mathrm{CO}_{3}\right)_{3}(\mathrm{~s})$ (where $\mathrm{M}$ is $\mathrm{Am}$ or $\mathrm{Nd}$ ) was found to be the stable solid. Runde and $\mathrm{Kim}$ [13] reported $\mathrm{NaAm}\left(\mathrm{CO}_{3}\right)_{2}$ (s) to be the stable solid phase in $5 \mathrm{M} \mathrm{NaCl}$ solution of neutral pH under 0.01 atm $\mathrm{CO}_{2}$ partial pressure. Furthermore, Kim et al. [14] used time-resolved laser-induced fluorescence spectroscopy to characterize europium(III) and curium(III) carbonate solids and their aqueous carbonato complexes in $0.1 \mathrm{M} \mathrm{NaClO}$, solutions, with $\mathrm{pH}$ from 4 to 10 and under 1 to $100 \% \mathrm{CO}_{2}$ partial pressure. In an attempt to summarize literature data on the solubility of three different solids $\left(\mathrm{Am}(\mathrm{OH})_{3}, \mathrm{AmOHCO}_{3}\right.$, and $\left.\mathrm{Am}_{2}\left(\mathrm{CO}_{3}\right)_{3}\right)$, Vitorge [15] discussed the utilization of the specific ion interaction (SIT) method to extrapolate the conditional $K_{s p}$ values to zero ionic strength, in which some difficulties and uncertainties were involved because of insufficient experimental data.

In summary, a literature survey indicates that 1) several different solid compounds may form, depending on the system conditions such as $\mathrm{pH}$, partial pressure of $\mathrm{CO}_{2}$, concentrations of total carbonate and other species (e.g. $\left.\mathrm{Na}^{+}\right)$; 2) a large variability exists in values of data on solubility products and stability constants for aqueous complexes; 3) most of the studies provided only the conditional solubility products in particular electrolyte media and at specific ionic strengths. The validity of extrapolation of those conditional constants to the reference state (zero ionic strength) remains uncertain.

To provide reliable thermodynamic information on the solid-liquid equilibria in the $\mathrm{Na}^{+}-\mathrm{Am}^{3+}-\mathrm{HCO}_{3}{ }^{-}-\mathrm{CO}_{3}{ }^{2-}-\mathrm{OH}^{-}-\mathrm{H}_{2} \mathrm{O}$ system, Felmy et al. [16] determined the solubility of $\mathrm{AmOH}\left(\mathrm{CO}_{3}\right)(\mathrm{c})$ at low total carbonate concentrations $(<0.1 \mathrm{M})$ over a wide $\mathrm{pH}$ range and reinterpreted the available solvent extraction data for americium-carbonate complexes. A thermodynamic model was developed and shown to be consistent with the solubility data 
in that work and the solvent extraction data of Bidoglio [4]. As an extension of that work and as a further effort to improve the thermodynamic models for the carbonate systems, the $\mathrm{Na}^{-}-\mathrm{Nd}^{3-}-\mathrm{HCO}_{3}^{-}-\mathrm{CO}_{3}{ }^{2-}-\mathrm{OH}^{-}-\mathrm{H}_{2} \mathrm{O}$ system at high carbonate and bicarbonate concentrations (0.1 $\mathrm{M}$ to near saturation) were studied. Our objectives were to 1 ) identify the thermodynamically stable solid phases under the experimental conditions, and 2) obtain the thermodynamic data on the stable solid phase and aqueous complexes and develop the necessary ion interaction parameters to describe this wide range of solubility data.

\section{Materials and Procedures}

\subsection{Stock Solutions and Reagents}

All chemical reagents used in this work were A.R. grade or higher. Double-distilled acids $\left(\mathrm{HNO}_{3}\right.$ and $\left.\mathrm{HCl}\right)$ were used when needed. Distilled and deionized water was used to prepare all solutions.

\subsection{Characterization of $\mathrm{Nd}_{2}\left(\mathrm{CO}_{3}\right)_{3} \cdot \mathrm{xH}_{2} \mathrm{O}(\mathrm{s})$}

Neodymium carbonate $\left(\mathrm{Nd}_{2}\left(\mathrm{CO}_{3}\right)_{3} \cdot \mathrm{xH}_{2} \mathrm{O}, 99.99 \%\right.$ purity) was purchased from Aldrich Chemical Company. X-ray diffraction (XRD) patterns of this solid indicated that $60 \%$ (by weight) of this solid was $\mathrm{Nd}_{2}\left(\mathrm{CO}_{3}\right)_{3} \cdot 2 \cdot 5 \mathrm{H}_{2} \mathrm{O}$ while the rest was unidentified neodymium carbonate compounds, possibly $\mathrm{Nd}_{2}\left(\mathrm{CO}_{3}\right)_{3}$ with different numbers of $\mathrm{H}_{2} \mathrm{O}$ molecules. This material was used without further purification as the initial solid in one series of the solubility experiments. 


\subsection{Preparation and Characterization of $\mathrm{NaNd}\left(\mathrm{CO}_{3}\right)_{2} \cdot 6 \mathrm{H}_{2} \mathrm{O}(\mathrm{c})$}

$\mathrm{NaNd}\left(\mathrm{CO}_{3}\right)_{2} \cdot 6 \mathrm{H}_{2} \mathrm{O}(\mathrm{c})$ was prepared by the following procedure based on the paper by Mochizuki et al. [17]. Into $30 \mathrm{~mL}$ of $0.3 \mathrm{M} \mathrm{NdCl}_{3}$ solution (pH about 3.2), $30 \mathrm{~mL}$ of 1.0 $\mathrm{M}$ sodium acetate $/ 1.0 \mathrm{M}$ acetic acid buffer ( $\mathrm{pH}$ about 5 ) was added and mixed thoroughly. Then, about $240 \mathrm{~mL}$ of $1 \mathrm{M} \mathrm{Na}_{2} \mathrm{CO}_{3}$ solution was slowly added into this buffered $\mathrm{NdCl}_{3}$ solution with vigorous stirring. The final $\mathrm{pH}$ of the suspension was about 7. The polyethylene bottle containing the suspension was shaken on an orbital shaker for 4 to 7 days. The suspension was then centrifuged and the precipitate was washed twice with deionized water before it was analyzed by XRD. The XRD patterns of the prepared compound were in good agreement with those for $\mathrm{NaNd}\left(\mathrm{CO}_{3}\right)_{2} \cdot 6 \mathrm{H}_{2} \mathrm{O}$ reported by Mochizuki et al. [17]. To avoid any phase changes, the washed "wet" $\mathrm{NaNd}\left(\mathrm{CO}_{3}\right)_{2} \cdot 6 \mathrm{H}_{2} \mathrm{O}(\mathrm{c})$ was directly transfered into the centrifuge tubes for solubility experiments.

\subsection{Solubility Experiments}

Two series of solubility experiments were performed, with $\mathrm{Nd}_{2}\left(\mathrm{CO}_{3}\right)_{3} \cdot \mathrm{xH}_{2} \mathrm{O}(\mathrm{s})$ and $\mathrm{NaNd}\left(\mathrm{CO}_{3}\right)_{2} \cdot 6 \mathrm{H}_{2} \mathrm{O}(\mathrm{c})$ as the initial solids, respectively. In each series, two sets of experiments were conducted: one set contained sodium carbonate in a concentration range of 0.1 to $2.0 \mathrm{M}$, the other set contained sodium bicarbonate in a concentration range of 0.1 to $1.06 \mathrm{M}$. As a result, the $\mathrm{pH}$ of the solutions in the first set was around 11 , while that in the second set was around 8 . The solubility experiments were carried out in $50 \mathrm{~mL}$ polypropylene centrifuge tubes, each containing enough initial solid to guarantee excess solid phase materials remaining after the system reached equilibrium. After the initial pH 
was measured, these centrifuge tubes were continuously shaken on an orbital shaker until the scheduled sampling and analysis.

The equilibration periods for the first series $\left(\mathrm{Nd}_{2}\left(\mathrm{CO}_{3}\right)_{3} . \mathrm{xH}_{2} \mathrm{O}\right.$ as the initial solid) were $15,48,78$, and 110 days, while the equilibration periods for the second series $\left(\mathrm{NaNd}\left(\mathrm{CO}_{3}\right)_{2} \cdot 6 \mathrm{H}_{2} \mathrm{O}\right.$ as the initial solid) were $14,46,76$, and 111 days.

\subsection{Analyses}

At the end of each equilibration period, the $\mathrm{pH}$ of the suspensions was measured with a combination glass electrode calibrated against standard $\mathrm{pH}$ buffers to determine the relative acid-base properties of the solutions. The suspensions were then centrifuged at about $2,000 \mathrm{~g}$ for 7 to 10 minutes. Samples of the supernatants were filtered through membranes (approximate pore size $=0.0018 \mu \mathrm{m}$, effective molecular-weight cutoff $=$ 25,000 ) based on the procedure developed by Rai et al. $[18,19]$. The procedure is as follows: 1) the filters were washed with deionized water; 2) $2.0 \mathrm{~mL}$ of the supernatant was passed through the filters to saturate any possible adsorption sites on the filters and filtration containers (this filtrate was discarded); 3) $6.0 \mathrm{~mL}$ of the supernatant was filtered.

Of the $6.0 \mathrm{~mL}$ of final filtrate, $1.0 \mathrm{~mL}$ was used for analysis of total inorganic carbon with a coulometric $\mathrm{CO}_{2}$ analyzer. The remaining $5.0 \mathrm{~mL}$ of filtrate was acidified with concentrated nitric acid and used for analysis of sodium and neodymium. Sodium was determined by inductively coupled plasma spectroscopy (ICP), while neodymium was analyzed by the inductively coupled plasma spectroscopy - mass spectrometry (ICP-MS) technique, with indium- 115 as the internal standard. The analytical errors in neodymium concentrations are estimated to be less than $10 \%$ in all cases. 
At the end of the sampling periods (110 and 111 days for the two series of experiments, respectively), wet samples of the solid phases were taken and analyzed by XRD

\section{Results and Discussion}

The change in aqueous neodymium concentrations as a function of equilibration periods ranging from 14 to 111 days indicates that neodymium concentrations reached steady states in about 15 days in the sodium carbonate systems (Figures $1 \mathrm{a}$ and $1 \mathrm{~b}$ ) and in 46 to 48 days in the sodium bicarbonate systems (Figures $1 \mathrm{c}$ and $1 \mathrm{~d}$ ). As a result, the data obtained from 14- and 15-day samplings of the sodium bicarbonate systems were not included in the subsequent development of the thermodynamic model.

In the bicarbonate systems containing $\mathrm{Nd}_{2}\left(\mathrm{CO}_{3}\right)_{3} \cdot \mathrm{xH}_{2} \mathrm{O}$ as the initial solid (Figure 1c), the neodymium concentrations at the 15-day sampling were lower than the steady state concentrations. This is understandable because the equilibrium was approached from undersaturation. However, when $\mathrm{NaNd}\left(\mathrm{CO}_{3}\right)_{2} \cdot 6 \mathrm{H}_{2} \mathrm{O}$ was used as the initial solid, the neodymium concentrations at the 14-day sampling were much higher than the steady state concentrations (Figure 1d). This is most likely because the $\mathrm{NaNd}\left(\mathrm{CO}_{3}\right)_{2} \cdot 6 \mathrm{H}_{2} \mathrm{O}$ was added in the "wet" form after washing with deionized water ( $\mathrm{pH}$ about 6). The solubility of $\mathrm{NaNd}\left(\mathrm{CO}_{3}\right)_{2} \cdot 6 \mathrm{H}_{2} \mathrm{O}$ at $\mathrm{pH} 6$ is expected to be significantly higher than the final equilibrium concentrations in these sodium bicarbonate systems at a $\mathrm{pH}$ of about 8 . In other words, the solid-liquid equilibrium was approached from oversaturation when "wet" $\mathrm{NaNd}\left(\mathrm{CO}_{3}\right)_{2} \cdot 6 \mathrm{H}_{2} \mathrm{O}$ was used as the initial solid. 


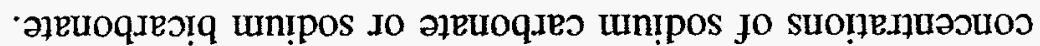

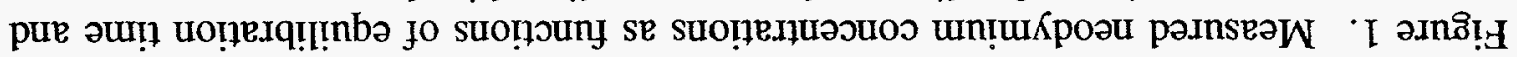

$\left[\varepsilon_{O} O H E N\right]$ SOI
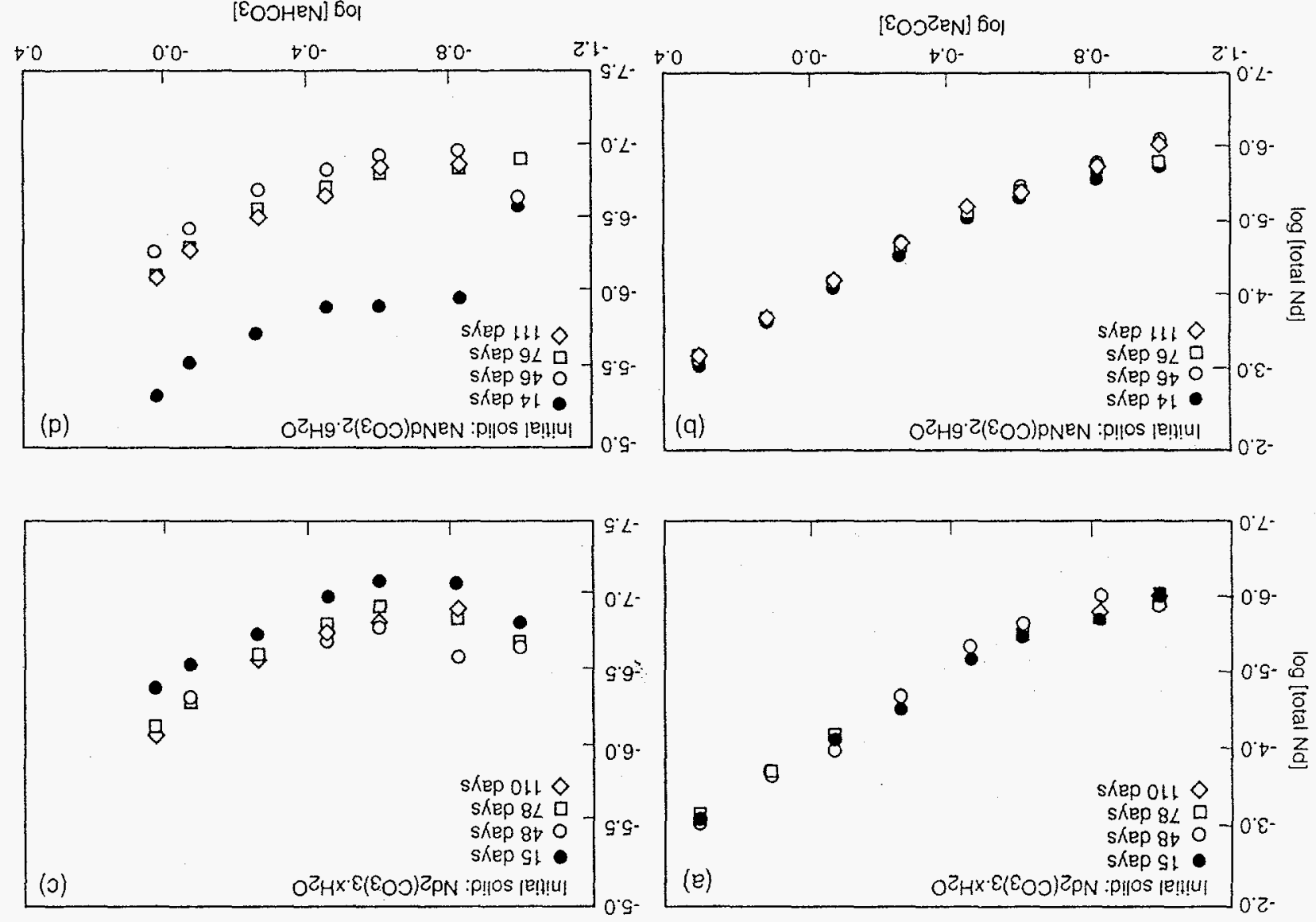
All the solid samples from the systems using $\mathrm{Nd}_{2}\left(\mathrm{CO}_{3}\right)_{3} . \mathrm{xH}_{2} \mathrm{O}$ as the initial solid and several representative solid samples from the systems using $\mathrm{NaNd}\left(\mathrm{CO}_{3}\right)_{2} \cdot 6 \mathrm{H}_{2} \mathrm{O}$ as the initial solid were analyzed by XRD. The XRD patterns of all the samples are consistent with those for $\mathrm{NaNd}\left(\mathrm{CO}_{3}\right)_{2} \cdot 6 \mathrm{H}_{2} \mathrm{O}[17]$.

The observations can be summarized as follows: 1) steady state concentrations were reached in 15 to 48 days, 2) final steady-state concentrations were similar when approached from undersaturation or oversaturation, and when obtained from $\mathrm{Nd}_{2}\left(\mathrm{CO}_{3}\right)_{3} \cdot \mathrm{xH}_{2} \mathrm{O}$ or $\mathrm{NaNd}\left(\mathrm{CO}_{3}\right)_{2} \cdot 6 \mathrm{H}_{2} \mathrm{O}(\mathrm{c})$ as the initial solid, 3) the final solid at the steady state was found to be $\mathrm{NaNd}\left(\mathrm{CO}_{3}\right)_{2} \cdot 6 \mathrm{H}_{2} \mathrm{O}(\mathrm{c})$. Based on these observations, we concluded that the steady-state neodymium concentrations represent the equilibrium solubility of $\mathrm{NaNd}\left(\mathrm{CO}_{3}\right)_{2} \cdot 6 \mathrm{H}_{2} \mathrm{O}(\mathrm{c})$ under the experimental conditions. Therefore, only the steady state data were used in the thermodynamic analysis.

\subsection{Thermodynamic Analysis and the Solubility Product of $\mathrm{NaNd}\left(\mathrm{CO}_{3}\right)_{2} \cdot 6 \mathrm{H}_{2} \mathrm{O}(\mathrm{c})$}

In the $\mathrm{Na}^{+}-\mathrm{Nd}^{3+}-\mathrm{HCO}_{3}-\mathrm{CO}_{3}{ }^{2-}-\mathrm{OH}^{-}-\mathrm{H}_{2} \mathrm{O}$ system, the equilibrium neodymium concentrations, i.e., the observed total $[\mathrm{Nd}]_{a q}$, were the sum of the concentrations of all aqueous neodymium species, which were in simultaneous equilibria with the solid phase. The aqueous species included $\mathrm{Nd}^{3+}$, neodymium hydroxy species, and various neodymium carbonato species. The observed changes in $[\mathrm{Nd}]_{a q}$ as functions of $\left[\mathrm{NaHCO}_{3}\right]$ or $\left[\mathrm{Na}_{2} \mathrm{CO}_{3}\right]$ were the overall effect of changes in ligand concentration and changes in the activity coefficients of various species in those equilibria. The dissolution of $\mathrm{NaNd}\left(\mathrm{CO}_{3}\right)_{2} \cdot 6 \mathrm{H}_{2} \mathrm{O}(\mathrm{c})$ can be expressed by the following reaction: 


$$
\mathrm{NaNd}\left(\mathrm{CO}_{3}\right)_{2} \cdot 6 \mathrm{H}_{2} \mathrm{O}(\mathrm{c})=\mathrm{Na}^{+}+\mathrm{Nd}^{3-}+2 \mathrm{CO}_{3}^{2-}+6 \mathrm{H}_{2} \mathrm{O}
$$

where $\mathrm{Nd}^{3+}$ is in simultaneous equilibria with other species such as

$$
\begin{array}{ll}
\mathrm{Nd}^{3+}+\mathrm{iOH}^{-}=\mathrm{Nd}(\mathrm{OH})_{i}^{(3-i)+} & \text { probable values of } \mathrm{i}=1,2,3 \\
\mathrm{Nd}^{3+}+\mathrm{jCO}_{3}{ }^{2-}=\mathrm{Nd}\left(\mathrm{CO}_{3}\right)_{j}{ }^{(2-3)} & \text { probable values of } \mathrm{j}=\mathrm{j}, 2,3
\end{array}
$$

To evaluate these equilibria simultaneously based on the experimental data, a nonlinear least-squares program (NONLIN) was used in combination with a chemical equilibrium program (GMIN) [16]. The NONLIN is based upon the algorithm of Harvie and associates $[20,21]$. Details of the minimization procedure have been outlined in previous publications $[22,23]$. In the current system, the quantity minimized was the statistical summation of $f(\chi)$ over all experimental points, where $f(\chi)$ was defined as

$$
\begin{aligned}
& f(\chi)=(\mu / R T)_{\text {solid }}-(\mu / R T)_{\text {solution }} \\
& =\left(\mu^{\circ} / \mathrm{RT}\right) \mathrm{NaNd}\left(\mathrm{CO}_{3}\right)_{2} \cdot 6 \mathrm{H}_{2} \mathrm{O}-\left\{\left(\mu^{\circ} / \mathrm{RT}\right) \mathrm{Na}^{*}+\left(\mu^{\mathrm{o}} / \mathrm{RT}\right) \mathrm{Nd}^{3+}+2\left(\mu^{\mathrm{o}} / \mathrm{RT}\right) \mathrm{CO}_{3}{ }^{-{ }^{-}}+\right. \\
& \left.\sigma\left(\mu^{\circ} / \mathrm{RT}\right) \mathrm{H}_{2} \mathrm{O}+\ln \left(\mathrm{m}_{\mathrm{Na}^{2}}+\gamma_{\mathrm{Na}^{+}}\right)+\ln \left(\mathrm{m}_{\mathrm{Nd}^{3}+\gamma_{\mathrm{Nd}^{3}}}\right)+2 \ln \left(\mathrm{m}_{\mathrm{CO}^{2}}-\gamma_{\mathrm{CO}^{2}}-\right)\right\}
\end{aligned}
$$

where $\mu^{\circ}$ is the standard chemical potential, $R$ is the gas constant, $T$ is temperature in degrees Kelvin, $m$ denotes the molality of the subscripted species, and $y$ refers to the activity coefficient of the subscripted species. 


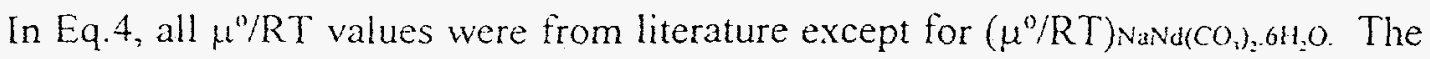
$[\mathrm{Na}]$ was determined by $\mathrm{ICP}$ analysis. The $\left[\mathrm{Nd}^{3+}\right]$ and $\left[\mathrm{CO}_{3^{2-}}{ }^{2-}\right.$ were calculated using the NONLIN program with the $\mu^{\circ} / \mathrm{RT}$ values for various aqueous species involved in the aqueous equilibria. The $\mu^{\circ} / \mathrm{RT}$ values used in the evaluation are listed in Table 1. Preliminary calculations that included the neodymium hydroxy species $\left(\mathrm{Nd}(\mathrm{OH})_{i}^{(3-i)+}, \mathrm{i}=\right.$ $1,2,3)$ indicated that these species were not significant in the concentrated carbonate or bicarbonate solutions. As a result, the $\mu^{\circ} / \mathrm{RT}$ values for $\mathrm{Nd}(\mathrm{OH})_{i}^{(3-i)-}$ were not included in Table 1 .

Besides the necessary $\mu^{\circ} / \mathrm{RT}$ values, the activity coefficients in Eq. 4 had to be calculated to evaluate the experimental data. In this study, the ion-interaction model of Pitzer et al. [26,27] was used to calculate the activity coefficients because of its broad applicability to solutions with zero to high ionic strengths. Based on Pitzer's model, the effects of the specific ion interactions on the excess solution free energy are represented within the activity coefficient expressions. A detailed description of these expressions are given elsewhere $[24,28]$. The complete set of parameters defining the non-ideal behavior of electrolytes include $\beta^{(0)}, \beta^{(1)}, \beta^{(2)}$ and $C^{\phi}$ for each cation-anion pair, $\Theta_{\mathrm{ij}}$ for each cationcation or anion-anion pair, $\psi_{\mathrm{ijk}}$ for each cation-cation-anion and anion-anion-cation triplet, and $\lambda_{\mathrm{in}}$ and $\delta_{\mathrm{ijn}}$ for each ion-neutral and ion-ion-neutral interactions. Some of these interaction parameters for the $\mathrm{Na}^{-}-\mathrm{Nd}^{3+}-\mathrm{HCO}_{3}^{-}-\mathrm{CO}_{3}{ }^{2-}-\mathrm{OH}^{-}-\mathrm{H}_{2} \mathrm{O}$ system were available from the literature [24] and are summarized in Table 2.

Felmy et al. [16] previously developed a thermodynamic model that provided satisfactory interpretation of the solubility of $\mathrm{AmOH}\left(\mathrm{CO}_{3}\right)(\mathrm{c})$ in less concentrated sodium 
Table 1 Chemical Species and their $\mu^{\%} /$ RT Values Used in This Study

\begin{tabular}{|c|c|c|}
\hline Species & $\mu \% \mathrm{RT}$ & Reference \\
\hline $\mathrm{H}_{2} \mathrm{O}$ & -95.663 & [24] \\
\hline $\mathrm{Na}^{+}$ & -105.651 & [24] \\
\hline $\mathrm{OH}^{-}$ & -63.435 & [24] \\
\hline $\mathrm{CO}_{3}{ }^{2-}$ & -212.944 & {$[24]$} \\
\hline $\mathrm{HCO}_{3}^{-}$ & -236.751 & [24] \\
\hline $\mathrm{CO}_{2}(\mathrm{aq})$ & -155.680 & [24] \\
\hline $\mathrm{Nd}^{3+}$ & -270.926 & [25] \\
\hline $\mathrm{NdCO}_{3}^{+}$ & -501.292 & {$[22]$} \\
\hline $\mathrm{Nd}\left(\mathrm{CO}_{3}\right)_{2}^{-}$ & -725.112 & {$[22]$} \\
\hline $\mathrm{Nd}\left(\mathrm{CO}_{3}\right)_{3}{ }^{3-}$ & -944.692 & [22] \\
\hline $\mathrm{NaNd}\left(\mathrm{CO}_{3}\right)_{2} \cdot 6 \mathrm{H}_{2} \mathrm{O}(\mathrm{c})$ & -1425.726 & this work \\
\hline
\end{tabular}


Table 2 Pitzer Ion-Interaction Parameters Used in This Study [24]

\begin{tabular}{|c|c|c|c|}
\hline \multirow[t]{3}{*}{ Species } & \multicolumn{3}{|c|}{ Ion-Interaction Parameters } \\
\hline & \multicolumn{3}{|c|}{ Binary System Interactions } \\
\hline & $\beta^{(0)}$ & $\beta^{(1)}$ & $C^{\phi}$ \\
\hline $\mathrm{Na}^{+}-\mathrm{HCO}_{3}^{-}$ & 0.0277 & 0.0411 & 0 \\
\hline $\mathrm{Na}^{+}-\mathrm{CO}_{3}{ }^{2-}$ & 0.0399 & 1.389 & 0.0044 \\
\hline \multirow[t]{2}{*}{$\mathrm{Na}^{+}-\mathrm{OH}^{-}$} & 0.0864 & 0.253 & 0.0044 \\
\hline & \multicolumn{3}{|c|}{ Common Ion Ternary System Interactions } \\
\hline $\mathrm{H}^{+}-\mathrm{Na}^{+}$ & 0.036 & & \\
\hline $\mathrm{OH}^{-}-\mathrm{CO}_{3}{ }^{2-}$ & 0.10 & & \\
\hline $\mathrm{OH}^{-}-\mathrm{CO}_{3}{ }^{2-}-\mathrm{Na}^{+}$ & -0.017 & & \\
\hline $\mathrm{CO}_{3}^{2-}-\mathrm{HCO}_{3}^{-}$ & -0.04 & & \\
\hline $\mathrm{CO}_{3}{ }^{2-}-\mathrm{HCO}_{3}-\mathrm{Na}^{+}$ & 0.002 & & \\
\hline
\end{tabular}


carbonate and bicarbonate solutions $(<0.1 \mathrm{M})$. In that model, the interactions between $\mathrm{Na}^{+}$ and $\mathrm{Am}\left(\mathrm{CO}_{3}\right)_{3}^{3-}$ were considered by including $\beta^{(1)}$ and $\beta^{(0)}$ parameters. The $\beta^{(1)}$ for $\mathrm{Na}^{+}-$ $\mathrm{Am}\left(\mathrm{CO}_{3}\right)_{3}{ }^{3-}$ interaction was fixed at the literature $\mathrm{\beta}^{(1)}$ value of 8.1 for $\mathrm{Na}^{+}-\mathrm{AsO}_{4}{ }^{3-}$ interaction, on the assumption that these two interactions were analogous. The $\beta^{(0)}$ was then adjusted to 0.24 to fit the solvent extraction data of Bidoglio [4]. Ideally, the same model might be applicable to the $\mathrm{Nd}(\mathrm{III})$ system, because $\mathrm{Nd}(\mathrm{III})$ has been demonstrated to be a good analog for trivalent actinide species [28,29]. However, when the model was tested with the solubility data for $\mathrm{Nd}(\mathrm{III})$ in the concentrated carbonate and bicarbonate solutions, it was found that 1) some adjustments of $\beta^{(0)}$ and/or $\beta^{(1)}$ for $\mathrm{Na}^{+}-\mathrm{Nd}\left(\mathrm{CO}_{3}\right)_{3}{ }^{3-}$ seemed to be necessary, and 2) including the $\mathrm{Na}^{+}-\mathrm{Nd}\left(\mathrm{CO}_{3}\right)_{2}^{-}$interaction into the model significantly improved the fitting of the present experimental data, especially for the sodium bicarbonate systems. It appeared that such ion interactions could not be ignored when $\mathrm{Nd}\left(\mathrm{CO}_{3}\right)_{2}{ }^{-}$ became a major aqueous neodymium species. Because $\beta^{(0)}$ and $\beta^{(1)}$ may be redundant in these solutions, improvements on the fitting could be achieved by adjusting either of them, but not both simultaneously. For the $\mathrm{Na}^{+}-\mathrm{Nd}\left(\mathrm{CO}_{3}\right)_{3}^{3-}$ interaction, we decided to fix $\beta^{(1)}$ at the same value as in the Am-carbonate and bicarbonate model [16] and adjust $\beta^{(0)}$ and $C^{\phi}$. For the $\mathrm{Na}^{+}-\mathrm{Nd}\left(\mathrm{CO}_{3}\right)_{2}{ }^{-}$interaction, only $\beta^{(1)}$ was included and adjusted because it significantly improved the fitting of the $\mathrm{Nd}(\mathrm{III})$ data in the lower sodium bicarbonate concentration region. The standard chemical potentials for aqueous $\mathrm{Nd}(\mathrm{III})$-carbonate species were fixed at the values calculated for the analogous Am(III) species by Felmy et al. $[16]$. 
Different models were tested, and the simplest model that was consistent with the solubility data in this study and those in Felmy et al. [16] is given in Table 3 . The negative value of $\beta^{(1)}$ for the $\mathrm{Na}^{+}-\mathrm{Nd}\left(\mathrm{CO}_{3}\right)_{2}{ }^{-}$interaction implies that there is a strong associative interaction between $\mathrm{Na}^{+}$and $\mathrm{Nd}\left(\mathrm{CO}_{3}\right)_{2}$, which is not surprising because the equilibrium solid phase was $\mathrm{NaNd}\left(\mathrm{CO}_{3}\right)_{2} \cdot 6 \mathrm{H}_{2} \mathrm{O}(\mathrm{c})$. We do not have a satisfactory interpretation for the opposite signs of $\beta^{(0)}$ and $\beta^{(1)}$ for the $\mathrm{Na}^{-}-\mathrm{Nd}\left(\mathrm{CO}_{3}\right)_{3}{ }^{3-}$ interaction on the basis of the currently available data. However, the opposite signs might indicate that some other interactions have not been entirely accounted for by the present model. Nevertheless, the current model provides a satisfactory interpretation of the available data over a wide range of concentrations. A better understanding of these systems requires more extensive studies in mixed electrolyte media.

The value of $\mu^{\circ} / \mathrm{RT}$ for $\mathrm{NaNd}\left(\mathrm{CO}_{3}\right)_{2} .6 \mathrm{H}_{2} \mathrm{O}(\mathrm{c})$ was calculated to be -1425.726 by this model, which corresponds to a $\mathrm{K}_{\mathrm{sp}}$ value of $10^{-21.40}$ for the reaction

$$
\mathrm{NaNd}\left(\mathrm{CO}_{3}\right)_{2} \cdot 6 \mathrm{H}_{2} \mathrm{O}(\mathrm{c})=\mathrm{Na}^{+}+\mathrm{Nd}^{3+}+2 \mathrm{CO}_{3}{ }^{2-}+6 \mathrm{H}_{2} \mathrm{O}
$$

This model provides a satisfactory fit to the solubility data of $\mathrm{NaNd}\left(\mathrm{CO}_{3}\right)_{2} \cdot 6 \mathrm{H}_{2} \mathrm{O}(\mathrm{c})$ in both the sodium carbonate and bicarbonate solutions (Figure 2).

Whether or not trivalent lanthanides and actinides form bicarbonato complexes in these systems has been a controversial subject in the literature. Bidoglio [4] represented his solvent extraction data in terms of aqueous complexes including $\mathrm{Am}\left(\mathrm{HCO}_{3}\right)^{2+}$ and Am $\left(\mathrm{HCO}_{3}\right)_{2}{ }^{+}$. However, the spectrophotometric experiments of Nitsche and Silva [29] did 
Table 3 Additional Ion-Interaction Parameters Developed in This Study

$\begin{array}{llll}\text { Species } & & \text { Ion-Interaction Parameters } \\ & \beta^{(0)} & \beta^{(1)} & \mathrm{C}^{\phi} \\ \mathrm{Na}^{+}-\mathrm{Nd}\left(\mathrm{CO}_{3}\right)_{3}{ }^{3-} & -0.94 & 8.10 & 0.418 \\ \mathrm{Na}^{+}-\mathrm{Nd}\left(\mathrm{CO}_{3}\right)_{2} & 0 & -8.37 & 0\end{array}$




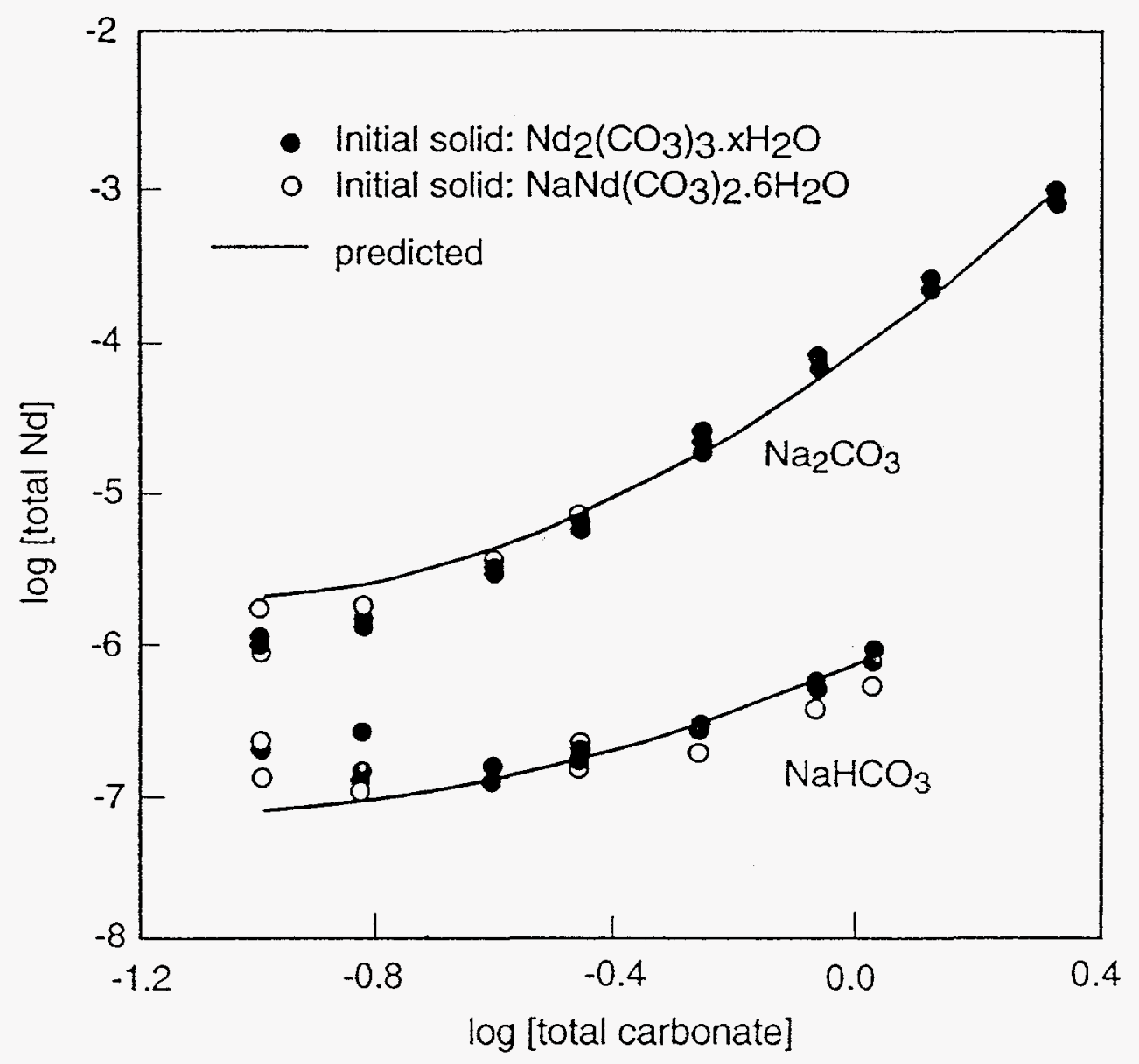

Figure 2. Solubility of $\mathrm{NaNd}\left(\mathrm{CO}_{3}\right)_{2} \bullet 6 \mathrm{H}_{2} \mathrm{O}$ (c) in sodium carbonate and sodium bicarbonate solutions. 
not support the existence of such complexes. Felmy et al. [16] found that both their solubility data and Bidoglio's solvent extraction data [4] could be well interpreted without invoking the americium bicarbonato complexes. In this study for the $\mathrm{Na}^{+}-\mathrm{Nd}^{3-}-\mathrm{HCO}_{3}^{-}-\mathrm{CO}_{3}{ }^{2-}$ $-\mathrm{OH}^{-}-\mathrm{H}_{2} \mathrm{O}$ system, the inclusion of $\mathrm{Nd}\left(\mathrm{HCO}_{3}\right)^{2+}$ and/or $\mathrm{Nd}\left(\mathrm{HCO}_{3}\right)_{2}{ }^{-}$complexes into the model did not provide satisfactory interpretation of the experimental data. As a result, these complexes were not invoked.

\subsection{Application of the Present Model in Less Concentrated Carbonate and}

\section{Bicarbonate Systems}

Developing a model that is applicable to systems covering a wide concentration range is desirable. Because the interaction parameters in the present model (Table 3 ) were developed based on the data for concentrated sodium carbonate and sodium bicarbonate solutions ( $0.1 \mathrm{M}$ to near saturation), the applicability of this model needed to be tested in less concentrated solutions. Based on the assumption that $\mathrm{Nd}(\mathrm{III})$ is a good analog of Am(III), this model was tested with the experimental solubility data [16] for the $\mathrm{Na}^{+}-\mathrm{Am}^{3+}-$ $\mathrm{HCO}_{3}-\mathrm{CO}_{3}{ }^{2-}-\mathrm{OH}^{-}-\mathrm{H}_{2} \mathrm{O}$ system at lower carbonate and bicarbonate concentrations $(<0.1 \mathrm{M})$ and over a wide $\mathrm{pH}$ range (Figure 3). The tests for the data in the $\mathrm{pH}$ region below 9.5 indicated that the predictions made with the present model are in very good agreement with the original data and with the previous model proposed by Felmy et al. [16] (Figure 3a and 3b). However, the predictions made with the two models deviate slightly from each other in the higher $\mathrm{pH}$ region. Nevertheless, even in the higher $\mathrm{pH}$ region (Figure $3 \mathrm{c}$ ), the present model provides satisfactory predictions. 

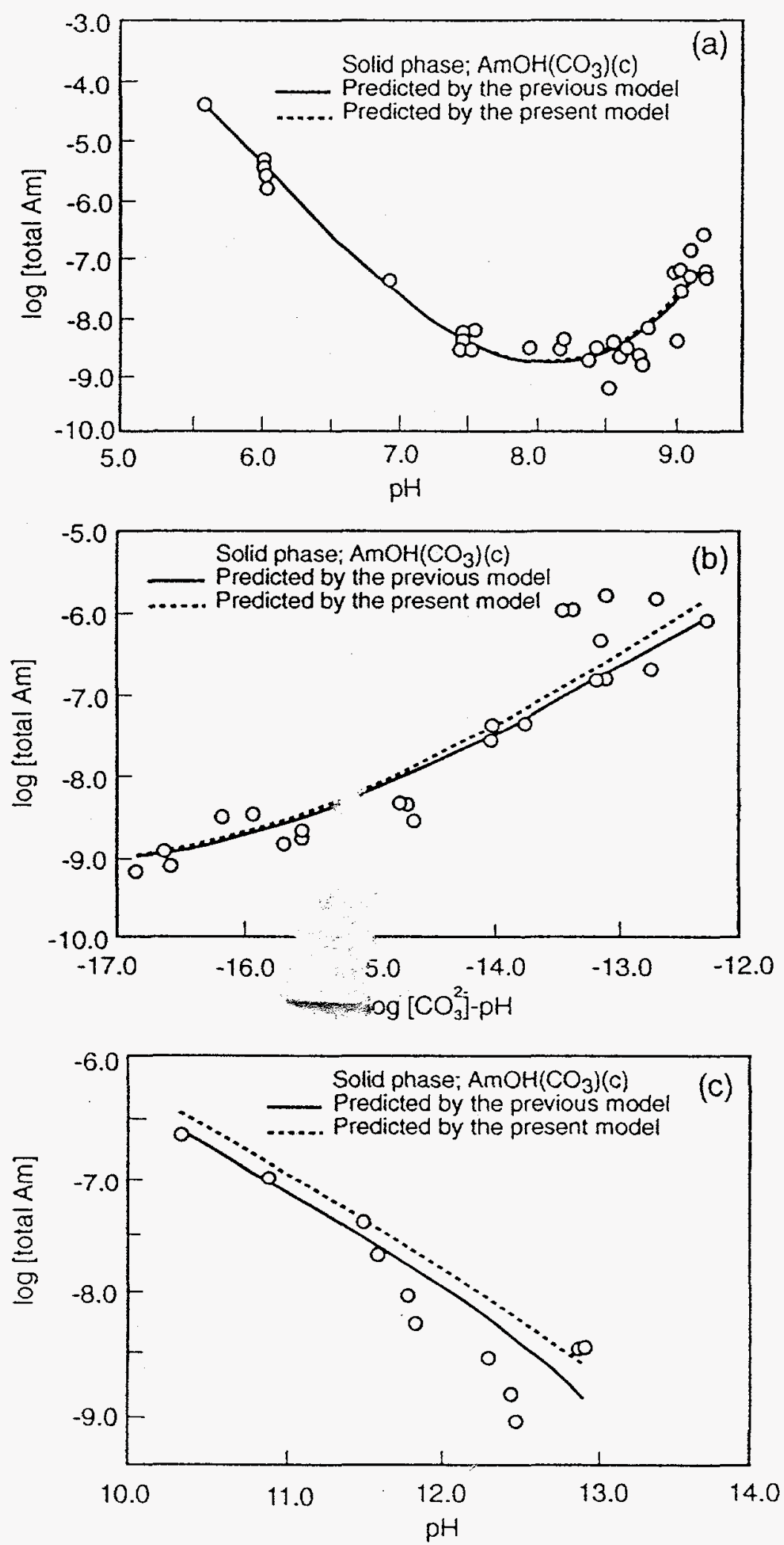

Figure 3. Comparison of the predictions for the $\mathrm{Na}^{+}-\mathrm{Am}^{3+}-\mathrm{HCO}_{3}-\mathrm{CO}_{3}^{2-}-\mathrm{OH}^{-}-\mathrm{H}_{2} \mathrm{O}$ system by the previous and the present models. 


\subsection{Solution Speciation and Stable Solid Phases}

Four aqueous $\mathrm{Nd}(\mathrm{III})$ species, i.e., $\mathrm{Nd}^{3+}, \mathrm{Nd}\left(\mathrm{CO}_{3}\right)^{-}, \mathrm{Nd}\left(\mathrm{CO}_{3}\right)_{2}$, and $\mathrm{Nd}\left(\mathrm{CO}_{3}\right)_{3}{ }^{3-}$, are invoked in this model. The model predicts that in the sodium carbonate solutions with $\left[\mathrm{Na}_{2} \mathrm{CO}_{3}\right]>0.1 \mathrm{M}, \mathrm{Nd}\left(\mathrm{CO}_{3}\right)_{3}{ }^{3-}$ is the only predominant species in the aqueous phase, while in the sodium bicarbonate solutions with $\left[\mathrm{NaHCO}_{3}\right]>0.1 \mathrm{M}$, both $\mathrm{Nd}\left(\mathrm{CO}_{3}\right)_{2}$ and $\mathrm{Nd}\left(\mathrm{CO}_{3}\right)_{3}{ }^{3-}$ exist in significant concentrations. Efforts were made to obtain experimental evidence for the existence of these neodymium species by the extended X-ray absorption fine structure (EXAFS) technique. Only a few samples with high carbonate concentrations were analyzed because the $[\text { total } \mathrm{Nd}]_{\mathrm{aq}}$ in other samples were too low for this technique. Preliminary analysis indicated that there are probably three carbonate groups in the primary coordination sphere of $\mathrm{Nd}(\mathrm{III})$ in the concentrated carbonate solutions, which is consistent with the prediction by the present model.

In the previous work on the $\mathrm{Na}^{+}-\mathrm{Am}^{3+}-\mathrm{HCO}_{3}^{-}-\mathrm{CO}_{3}^{--}-\mathrm{OH}^{-}-\mathrm{H}_{2} \mathrm{O}$ system at lower carbonate and bicarbonate concentrations $(<0.1 \mathrm{M})[16]$, the stable solid phase was found to be the hydroxycarbonato compound of $\mathrm{Am}(\mathrm{III}), \mathrm{AmOH}\left(\mathrm{CO}_{3}\right)(\mathrm{c})\left(\mathrm{K}_{\mathrm{sp}}=10^{-22.5}\right)$. However, in this study on the $\mathrm{Na}^{+}-\mathrm{Nd}^{3+}-\mathrm{HCO}_{3}^{-}-\mathrm{CO}_{3}{ }^{2-}-\mathrm{OH}^{-}-\mathrm{H}_{2} \mathrm{O}$ system at higher carbonate and bicarbonate concentrations, the stable solid phase was found to be $\mathrm{NaNd}\left(\mathrm{CO}_{3}\right)_{2} \cdot 6 \mathrm{H}_{2} \mathrm{O}(\mathrm{c})$, with a $\mathrm{K}_{\mathrm{sp}}$ value of $10^{-21.4}$. It is interesting to use the available thermodynamic data and predict the stable regions for these two types of solid phases, i.e., $\mathrm{NaM}\left(\mathrm{CO}_{3}\right)_{2} \cdot 6 \mathrm{H}_{2} \mathrm{O}(\mathrm{c})$ and $\mathrm{MOH}\left(\mathrm{CO}_{3}\right)(\mathrm{c})(\mathrm{M}$ is $\mathrm{Am}$ or $\mathrm{Nd})$. The phase transition between $\mathrm{NaM}\left(\mathrm{CO}_{3}\right)_{2} \cdot 6 \mathrm{H}_{2} \mathrm{O}(\mathrm{c})$ and $\mathrm{MOH}\left(\mathrm{CO}_{3}\right)(\mathrm{c})$ can be expressed by the following reaction: 


$$
\mathrm{NaM}\left(\mathrm{CO}_{3}\right)_{2} \cdot 6 \mathrm{H}_{2} \mathrm{O}(\mathrm{c})=\mathrm{MOH}\left(\mathrm{CO}_{3}\right)(\mathrm{c})+\mathrm{Na}^{+}+\mathrm{CO}_{3}{ }^{2-}+\mathrm{H}^{-}+5 \mathrm{H}_{2} \mathrm{O}
$$

This equilibrium depends on several factors such as $\mathrm{pH}$ and concentrations of carbonate and sodium ion. From the available chemical potential values for the species participating in this reaction, the equilibrium constant $\left(\mathrm{K}_{\mathrm{eq}}\right)$ for equation 6 can be calculated. Based on this reaction, if $\left\{\log \left[\mathrm{Na}^{+}\right]+\log \left[\mathrm{CO}_{3}{ }^{2-}\right]\right\}$ is plotted against $\mathrm{pH}$, the equilibrium between these two solid phases will be represented by a straight line with a slope of +1 and an intercept of $\log \mathrm{K}_{\mathrm{eq}}$. Figure 4 is such a plot, and it shows the equilibrium line dividing the two phases. Experimental points for $\mathrm{NaM}\left(\mathrm{CO}_{3}\right)_{2} \cdot 6 \mathrm{H}_{2} \mathrm{O}(\mathrm{c})$ from this work and those for $\mathrm{MOH}\left(\mathrm{CO}_{3}\right)(\mathrm{c})$ in literature are also included in the plot. As Figure 4 indicates, most of the experimental points consistently fall in the right region for the identified solid phase. Only a few points from the $\mathrm{Na}^{+}-\mathrm{Am}^{3+}-\mathrm{HCO}_{3}{ }^{-}-\mathrm{CO}_{3}{ }^{2-}-\mathrm{OH}^{-}-\mathrm{H}_{2} \mathrm{O}$ system [16] seem to be in the wrong phase region. Those points correspond to the solubility data for the two highest carbonate concentration solutions at 30 and 44 days of aging in the $\mathrm{Na}^{-}-\mathrm{Am}^{3+}-\mathrm{HCO}_{3}^{-}-\mathrm{CO}_{3}{ }^{2-}-$ $\mathrm{OH}^{-}-\mathrm{H}_{2} \mathrm{O}$ system [16]. Felmy et al. noticed that those data points significantly deviated from their model prediction (Figure 9 in Felmy et al. [16]). Probably the uncertainty in identifying the solid phases for those few points is responsible for these discrepancies.

\section{Summary}

$\mathrm{NaNd}\left(\mathrm{CO}_{3}\right)_{2} \cdot 6 \mathrm{H}_{2} \mathrm{O}(\mathrm{c})$ was identified to be the thermodynamically stable solid phase in sodium carbonate and sodium bicarbonate solutions $(0.1 \mathrm{M}$ to near saturation). The solubility product of $\mathrm{NaNd}\left(\mathrm{CO}_{3}\right)_{2} \cdot 6 \mathrm{H}_{2} \mathrm{O}(\mathrm{c})$ was calculated based on the thermodynamic model developed for the present $\mathrm{Na}^{+}-\mathrm{Nd}^{3+}-\mathrm{HCO}_{3}{ }^{-}-\mathrm{CO}_{3}{ }^{2-}-\mathrm{OH}^{-}-\mathrm{H}_{2} \mathrm{O}$ system. This model is 


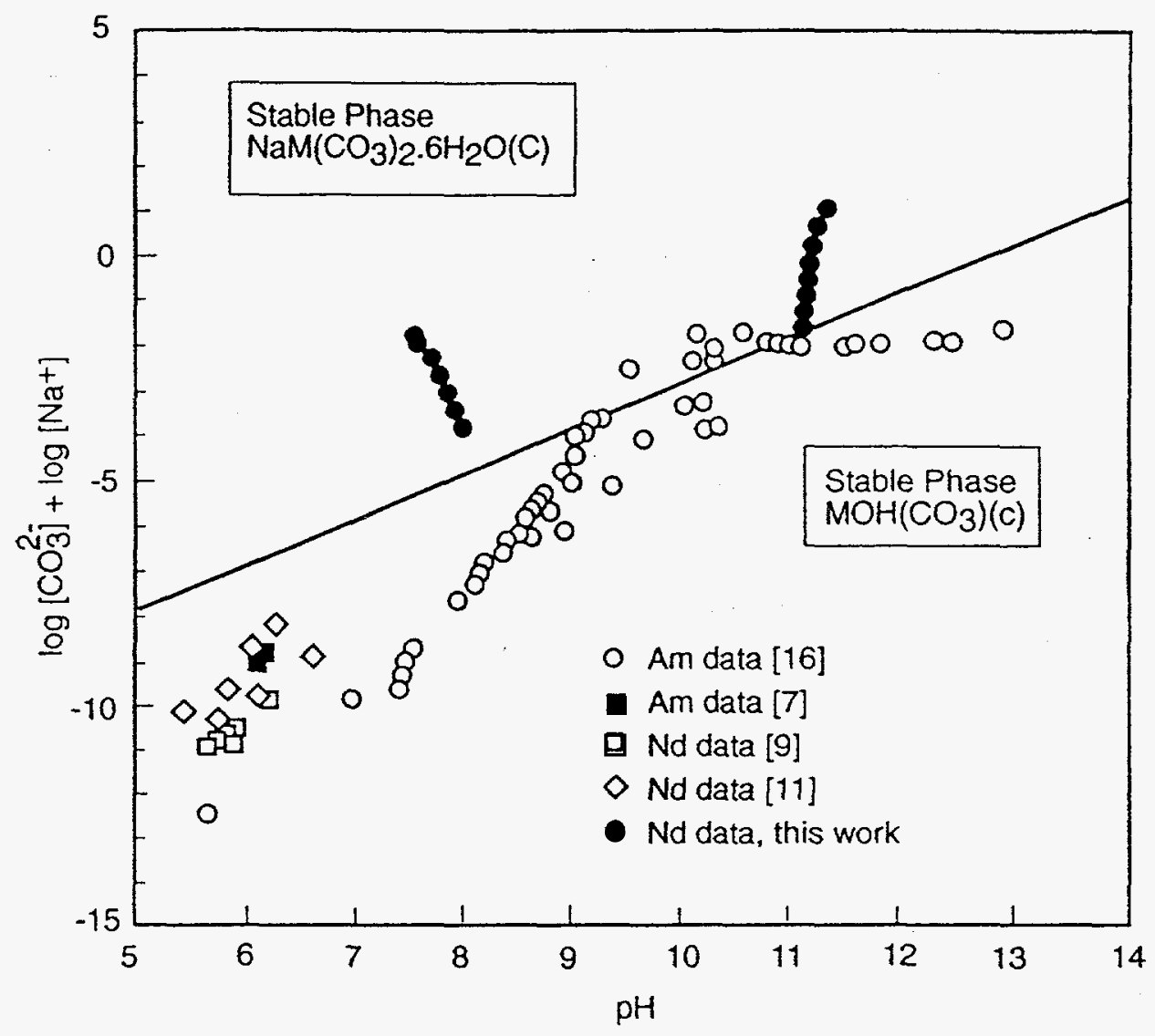

Figure 4. Phase transition between $\operatorname{NaM}\left(\mathrm{CO}_{3}\right)_{2} \bullet 6 \mathrm{H}_{2} \mathrm{O}(\mathrm{c})$ and $\mathrm{MOH}\left(\mathrm{CO}_{3}\right)(\mathrm{c})$. 
in good agreement with the solubility data for the $\mathrm{Am}(\mathrm{III})$ and $\mathrm{Nd}(\mathrm{III})$ carbonate systems covering a wide range of carbonate concentrations (dilute to near saturation). Values of Pitzer parameters for the ion interactions of $\mathrm{Na}^{+}-\mathrm{Nd}\left(\mathrm{CO}_{3}\right)_{3}{ }^{3-}$ and $\mathrm{Na}^{+}-\mathrm{Nd}\left(\mathrm{CO}_{3}\right)_{2}^{-}$were developed. Further testing of this model is planned in mixed electrolyte solutions of sodium chloride - sodium bicarbonate and sodium chloride - sodium carbonate.

\section{Acknowledgments}

The work described in this report was done for Sandia National Laboratories under Contract No. AF-3339. The authors are thankful to C.F.Novak, the Sandia Project Manager, for his encouragement and technical support throughout this study. Thanks are also due to J.E. Amonette and J.P.Zipperer for the EXAFS analysis, and to K.L.Manke for editorial assistance. 


\section{References}

1. White, D.E., J.D. Hem, and G.A. Waring. 1963. Data of Geochemistry. Sixth Edition. Chapter F. Chemical Composition of Subsurface Waters. Geological Survey Professional Paper 440-F. Washington: United States Government Printing Office. F1-F67.

2. Kim, J.I. 1989. "The Chemical Behavior of Actinides in Natural Aquatic Systems," The 1989 International Chemical Congress of Pacific Basin Societies: Abstracts of Papers, Parts I and II. Paper INOR 648. Washington, DC: American Chemical Society. 696-697.

3. Lundqvist, R. 1982. "Hydrophilic Complexes of the Actinides. 1. Carbonates of Trivalent Americium and Europium," Acta Chemica Scandinavica. Series A. Vol. 36, no. 9, 741-750.

4. Bidoglio, G. 1982. "Characterization of Am(III) Complexes with Bicarbonate and Carbonate Ions at Groundwater Concentration Levels," Radiochemical and Radioanalytical Letters. Vol. 53, no. $1,45-60$.

5. Bernkopf, M.F., and J.I. Kim. 1984. Hydrolysereaktionen und Karbonatkomplexierung von Dreiwertigem Americium im Naturlichen Aquatischen System. RCM-02884. Munich: Institut für Radiochemie der Technischen Universität.

6. Shiloh, M., M. Givon, and Y. Marcus. 1969. "A Spectrophotometric study of Trivalent Actinide Complexes in Solutions-III[1]. Americium with Bromide, Iodide, Nitrate and Carbonate Ligands[2]," Journal of Inorganic and Nuclear Chemistry. Vol. 31, 1807-1814.

7. Silva, R.J., and H. Nitsche. 1984. "Thermodynamic Properties of Chemical Species of Waste Radionuclides," NRC Nuclear Waste Geochemistry 1983, Reston, VA, August 30, 1983. Eds. D.H. Alexander and G.F. Birchard. NUREG/CP-0052. Washington, DC: Nuclear Regulatory Commission, Office of Nuclear Regulatory Research. 70-93.

8. Firsching, F.H., and J. Mohammadzadei. 1986. "Solubility Products of the Rare-Earth Carbonates," Journal of Chemical Engineering. Vol. 31, no. 1, 40-42.

9. Meinrath, G., and J.I. Kim. 1991. "Solubility Products of Different Americium(III) and Neodymium(III) Carbonates," European Journal of Solid state and Inorganic Chemistry. Vol. $28,383-388$.

10. Meinrath, G. and J.I. Kim. 1991. "The Carbonate Complexation of the Am(III) Ion," Radiochimica Acta. Vol. 52/53, pt. 1, 2934 .

11. Meinrath, G., and H. Takeishi. 1993. "Solid-Liquid Equilibria 
of $\mathrm{Nd}^{3+}$ in Carbonate Solutions," Journal of Alloys and Compounds. Vol. 194, no. 1, 93-99.

12. Runde, W., G. Meinrath, and J.I. Kim. 1992. "A Study of SolidLiquid Phase Equilibria of Trivalent Lanthanide and Actinide Ions in Carbonate Systems," Radiochimica Acta. Vol. 58-59, pt. $1,93-100$.

13. Runde, W., and J.I. Kim. 1993. "Solid-Liquid Phase Equilibria of $\mathrm{Am}$ (III) and $\mathrm{Am}(\mathrm{V})$ in Carbonate Containing NaCl solution," Actinides-93 International Conference, Final Program and Abstracts, Santa Fe, NM, September 19-23, 1993. Abstract 67. (Copy on file at the Sandia WIPP Central Files, sandia National Laboratories, Albuquerque, NM.)

14. Kim, J.I., R. Klenze, H. Wimmer, W. Runde, and W. Hauser. 1994. "A study of the Carbonate Complexation of $\mathrm{Cm}^{\mathrm{III}}$ and Eu" by Time-Resolved Laser-Induced Fluorescence Spectroscopy," Journal of Alloys and Compounds. Vol. 213/214, 333-340.

15. Vitorge, P. 1992. “Am(OH) 3 (s), $\operatorname{AmOHCO}_{3}(\mathrm{~s}), \mathrm{Am}_{2}\left(\mathrm{CO}_{3}\right)_{3}(\mathrm{~s})$ Stabilities in Environmental Conditions," Radiochimica Acta. Vol. 58-59, pt. 1, 105-107.

16. Felmy, A.R., D. Rai, and R.W. Fulton. 1990. "The Solubility of $\mathrm{AmOHCO}_{3}(\mathrm{C})$ and the Aqueous Thermodynamics of the system $\mathrm{Na}^{+}-\mathrm{Am}^{3+}-\mathrm{HCO}_{3}^{2}-\mathrm{OH}^{-}-\mathrm{H}_{2} \mathrm{O}$," Radiochimica Acta. Vol. 50, no. 4, 193204 .

17. Mochizuki, A., K. Nagashima, and H. Wakita. 1974. "Synthesis of Crystalline Hydrated Double Carbonates of Rare Earth Elements and Sodium," Bulletin of the Chemical Society of Japan. Vol. 47, no. 3, 755-756.

18. Rai, D., R.G. Strickert, D.A. Moore, and J.L. Ryan. 1983. "Am(III) Hydrolysis Constants and Solubility of Am(III) Hydroxide," Radiochimica Acta. Vol. 33, no. 4, 201-206.

19. Rai, D. 1984. "Solubility Product of Pu(IV) Hydrous Oxide and Equilibrium Constants of $\mathrm{Pu}(\mathrm{IV}) / \mathrm{Pu}(\mathrm{V}), \mathrm{Pu}(\mathrm{IV}) / \mathrm{Pu}(\mathrm{VI})$, and $\mathrm{Pu}(\mathrm{V}) / \mathrm{Pu}$ (VI) Couples," Radiochimica Acta. Vol. 35, no. 2, 97106.

20. Harvie, C.E. 1981. "Theoretical Investigations in Geochemistry and Atom Surface Scattering." Ph.D. dissertation. San Diego, CA: University of California.

21. Harvie, C.E., J.P. Greenberg, and J.H. Weare. 1987. "AChemical Equilibrium Algorithm for Highly Non-Ideal Multiphase Systems: Free Energy Minimization," Geochimica et Cosmochimica Acta. vol. 51, no. 5, 1045-1057.

22. Rai, D., A.R. Felmy, R.W. Fulton, and J.L. Ryan. 1992. "Aqueous Chemistry of Neodymium in Borosilicate-Glass/Water 
Systems," Radiochimica Acta. Vol. 58-59, pt. 1, 9-16.

23. Rai, D., A.R. Felmy, and R.W. Fulton. 1992. "Solubility and Ion Activity Product of Americium Phosphate Hydrate," Radiochimica Acta. Vol. 56, no. 1, 7-14.

24. Harvie, C.E., N. Moller, and J.H. Weare. 1984. "The Prediction of Mineral Solubilities in Natural Waters: The Na$\mathrm{K}-\mathrm{Mg}-\mathrm{Ca}-\mathrm{H}-\mathrm{Cl}-\mathrm{SO}_{4}-\mathrm{OH}-\mathrm{HCO}_{3}-\mathrm{CO}_{3}-\mathrm{H}_{2} \mathrm{O}$ System to $\mathrm{High}$ Ionic strengths at $25^{\circ} \mathrm{C}$," Geochimica et Cosmochimica Acta. Vol. 48, no. 4, $723-751$.

25. Wagman, D.D., W.H. Evans, V.B. Parker, R.H. Schumm, I. Halow, S.M. Bailey, K.L. Churney, and R.L. Nuttall. 1982. "The NBS Tables of Chemical Thermodynamic Properties. Selected Values for Inorganic and $\mathrm{C} 1$ and $\mathrm{C} 2$ Organic Substances in SI Units," Journal of Physical and Chemical Reference Data. Vol. 11, Supplement No. 2 .

26. Pytkowicz, R.M., ed. 1979. Activity Coefficients in Electrolyte Solutions. 1st ed. West Palm Beach, FL: CRC Press.

27. Pitzer, K.S., and G. Mayorga. 1973. "Thermodynamics of Electrolytes. II. Activity and Osmotic Coefficients for Strong Electrolytes with one or Both Ions Univalent," Journal of Physical Chemistry. Vol. 77, no. 19, 2300-2308.

28. Felmy, A.R., D. Rai, J.A. Schramke, and J.L. Ryan. 1989. "The Solubility of Plutonium Hydroxide in Dilute solution and in High-Ionic-Strength Chloride Brines," Radiochimica Acta. Vol. 48 , no. $1 / 2,29-35$.

29. Nitsche, H., E.M. Standifer, and R.J. Silva. 1989. "Americium(III) Carbonate Complexation in Aqueous Perchlorate Solution," Radiochimica Acta. Vol. 46, no. 4, 185-189. 
This page intentionally left blank. 
Thermodynamic Modeling of Neptunium(V) Solubility in Concentrated $\mathrm{Na}-\mathrm{CO}_{3}-\mathrm{HCO}_{3}-\mathrm{Cl}-\mathrm{ClO}_{4}-\mathrm{H}-\mathrm{OH}-\mathrm{H}_{2} \mathrm{O}$ Systems 
This page intentionally left blank. 
THERMODYNAMIC MODELING OF NEPTUNIUM(V) SOLUBILITY IN CONCENTRATED Na-CO $-\mathrm{CCO}_{3}-\mathrm{Cl}-\mathrm{ClO}_{4}-\mathrm{H}-\mathrm{OH}-\mathrm{H}_{2} \mathrm{O}$ SYSTEMS, Craig F. Novak ${ }^{*}$ and Kevin E. Roberts**

* Sandia National Laboratories, MS 1320, P.O. Box 5800, Albuquerque, NM 87185-1320 USA

** Lawrence Berkeley Laboratory, MS 70A-1115, 1 Cyclotron Road, Berkeley, CA 94270 USA

\section{ABSTRACT}

Safety assessments of nuclear waste repositories often require estimation of actinide solubilities as they vary with groundwater composition. Although a considerable amount of research has been done on the solubility and speciation of actinides, ${ }^{1,2}$ relatively little has been done to unify these data into a model applicable to concentrated brines. Numerous authors report data on the aqueous chemical properties of $\mathrm{Np}(\mathrm{V})$ in $\mathrm{NaClO}_{4}, \mathrm{Na}_{2} \mathrm{CO}_{3}$, and $\mathrm{NaCl}$ media, but a consistent thermodynamic model for predicting these properties is not available. To meet this need, a model was developed to describe the solubility of $\mathrm{Np}(\mathrm{V})$ in $\mathrm{Na}-\mathrm{Cl}-\mathrm{ClO}_{4}-\mathrm{CO}_{3}$ aqueous systems, based on the Pitzer activity coefficient formalism for concentrated electrolytes. Hydrolysis and/or carbonate complexation are the dominant aqueous reactions with the neptunyl ion in these systems. Literature data for neptunyl ion extraction and solubility are used to parameterize an integrated model for $\mathrm{Np}(\mathrm{V})$ solubility in the $\mathrm{Np}(\mathrm{V})-\mathrm{Na}-\mathrm{CO}_{3}-\mathrm{HCO}_{3}-\mathrm{Cl}-\mathrm{ClO}_{4}-\mathrm{H}-\mathrm{OH}-$ $\mathrm{H}_{2} \mathrm{O}$ system. The resulting model is tested against additional solubility and extraction data, and compared with $N p(V)$ solubility experiments in complex synthetic brines.

\section{The Pitzer Actrvity CoefFicient Model}

The Pitzer activity coefficient model $^{3}$ is a semi-empirical formalism describing the thermodynamics of electrolyte systems. Model parameterizations exist for brine evaporite systems 4,5 and, in a more limited fashion, for + III and + IV actinides in brines. $6,7,8,9$ The model is general enough to describe solutions from dilute to high concentration, and is formalized for complex electrolytes such as natural brines. Activity coefficients are represented by a virial expansion which, truncated to binary interactions, has the form

$$
\ln \gamma_{m}=z_{m}^{2} F+2 \sum_{a=1}^{N_{a}} m_{a} B_{m a}(I)
$$

for cation " $m$ "

where $F$ represents the Debye-Hückel term, $N_{a}$ is the number of anions, and $z_{m}$ is the charge on cation $\mathrm{m}$. A similar expression holds for anions. The complete forms of the equations and extensive discussion are given elsewhere. 3,4 The second virial coefficients $B_{m a}(1)$ are functions of the ionic strength, and are given by the relationship

$$
B_{m a}^{(I)} \equiv \beta_{m a}^{(0)}+\beta_{m a}^{(1)} g\left(\alpha_{m a} \sqrt{I}\right)+\beta_{m a}^{(2)} g(12 \sqrt{1}) \quad \text { for cation "m," anion "a" }
$$

where $\beta_{m a}^{(0)}, \beta_{m a}^{(1)}$, and $\beta_{m a}^{(2)}$ are parameters that are important at high, intermediate, and low ionic strength, respectively, and $g(y)$ is a decaying exponential function of the argument. When only the $\beta_{\mathrm{ma}}^{(0)}$ coefficient is nonzero, this model is similar to SIT, ${ }^{10}$ although a species molality, not the total ionic strength, multiplies this coefficient. The following sections discuss the process of determining $\beta_{\mathrm{ma}}^{(0)}$ and $\beta_{\mathrm{ma}}^{(1)}$ values and standard chemical potentials for the Np(V) system.

\section{Developing and Testing The NP(V) Solubility Model}

Brief descriptions of the data used to parameterize and test the model are given below. Selection of data sets for model development was based in part on evaluations in reviews or compilation for actinides. 1,11.12 Experimental details can be found in the source reports. Data interpretation was performed using the computer code NONLIN (developed by A.R. Felmy, uses 
the MINPACK nonlinear least-squares programs in combination with a chemical equilibrium program based on the Gibbs free-energy minimization procedure of Harvie et al. ${ }^{13}$ ); comparison of the parameterization with the experimental data were made using either NONLIN (Versions MacNONLIN 94.05.13b for solubility and MacNONLINex 94.07.09 for extraction) or FMT (FMT Version 1.0, a geochemical transport code under development by C.F. Novak).

The general parameterization process begins with the least complex data sets, or data sets from which one can determine the fewest number of parameters. As each parameter is generated, it is tested whenever possible by comparison against independent data. When an acceptable fit is obtained, these parameter values are fixed and held constant through the remaining parameter determinations. The data sets used to parameterize and test the $\mathrm{Np}(\mathrm{V})$ solubility model are summarized in Table I. Most of the data in Table I were taken at $25^{\circ} \mathrm{C}$, although several of the experiments were at $20^{\circ} \mathrm{C},{ }^{14}$ as is the work first reported here. The slight temperature dependence of the equilibrium constants and Pitzer ion interaction parameters over this small temperature range were neglected in this study. In total, the model parameterization calculated eight standard chemical potentials and six ion interaction parameters. Fixed parameters from the literature are in Table II; calculated standard chemical potentials and ion interaction parameters are in Tables III and IV.

Neptunyl Interactions with Perchlorate and Chloride (Data Series P1, P2; T1, T2)

Data measuring the extraction of $\mathrm{Np}(\mathrm{V})$ with sodium dinonylnaphthalenesulfonate ( $N a D N N S$ ) from $0.2-5 \mathrm{M} \mathrm{NaClO}_{4}$ or $\mathrm{NaCl}$ solutions ${ }^{15}$ were used to determine interaction parameters between $\mathrm{NpO}_{2}^{+}$and $\mathrm{ClO}_{4}^{-}$, and $\mathrm{NpO}_{2}^{+}$and $\mathrm{Cl}^{-}$. The experimental distribution coefficients $\mathrm{D}=\mathrm{m}_{\mathrm{Np}(\mathrm{o})} / \mathrm{m}_{\mathrm{Np}(\mathrm{aq})}$ are shown in Fig. $1 \mathrm{a}$ along with the fitted models. Note that neither $\mathrm{Cl}^{-}$nor $\mathrm{ClO}_{4}$ complexes were required to fit the data. These values are used to predict $\mathrm{Np}(\mathrm{V})$ extraction equilibria in $\mathrm{NaCl} / \mathrm{NaClO}_{4}$ mixtures at $2 \mathrm{M}$ total ionic strength ${ }^{16}$ and $5 \mathrm{M}$ total ionic strength, ${ }^{15}$ where $\mathrm{D}^{\circ}$ is the measured distribution coefficient when no $\mathrm{Cl}^{-}$is present. Fig. $1 \mathrm{~b}$ shows that the model prediction compares quite well with experimental values.
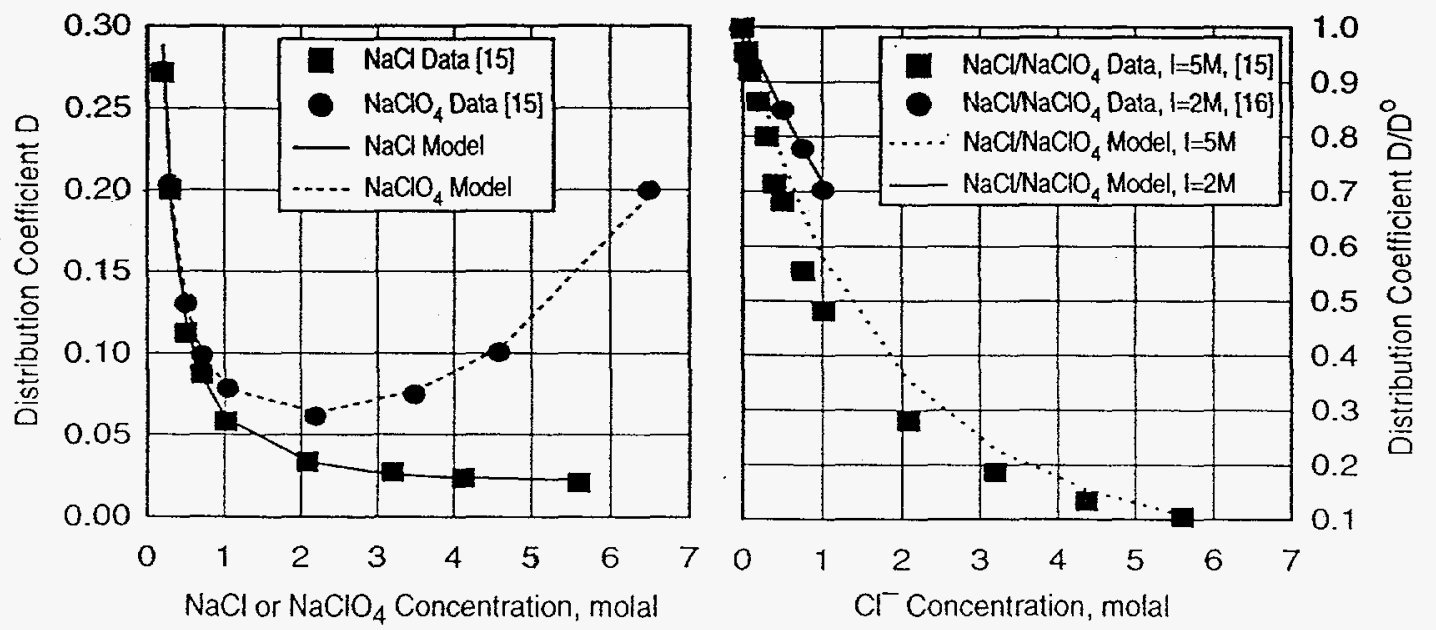

Figure 1. Solvent extraction data of $\mathrm{Np}(\mathrm{V})$ with $\mathrm{NaDNNS}$ from (a) $\mathrm{NaCl}$ or $\mathrm{NaClO}_{4}$ media, ${ }^{15}$ with

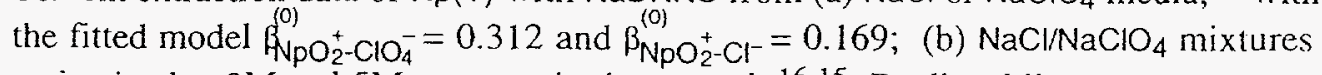
maintained at $2 \mathrm{M}$ and $5 \mathrm{M}$ constant ionic strength. ${ }^{16,15}$ Predicted lines use parameter values obtained in Fig. 1a.

Neptunyl Hydroxide Solids and Neptunyl Hydrolysis (Data Series P3; T3)

The solubility of $\mathrm{NpO}_{2} \mathrm{OH}$ (am/aged) in $0.1,1$, and $3 \mathrm{M} \mathrm{NaClO}_{4}$ as a function of $\mathrm{OH}^{-}$ concentration were investigated, 17,18 and the data are plotted in Fig. 2. The solubility of 
Table I. Experimental systems used to parameterize (P) and test (T) the Np(V) solubility model. A single value was determined for each of the fourteen parameters using data in the $P$ series. These values were tested as often as appropriate against the data listed as the $T$ series. The final two experimental systems provided an overall comparison of the model with data.

\begin{tabular}{|c|c|c|c|c|c|}
\hline $\mathrm{P} \pi$ & System & Medium & Type & Parameters Calculated & Ref. \\
\hline $\mathrm{P1}$ & $\mathrm{NpO}_{2}^{+} \mathrm{Cl}^{-}$ & $0.2-5.0 \mathrm{M} \mathrm{NaCl}$ & extr & $\beta_{\mathrm{NpO}_{2}^{+}-\mathrm{Cr}}^{(0)}$ & 15 \\
\hline $\mathrm{P} 2$ & $\mathrm{NpO}_{2}^{+}-\mathrm{ClO}_{4}^{-}$ & $0.2-5.0 \mathrm{M} \mathrm{NaClO} 4$ & extr & $\beta_{\mathrm{NpO}_{2}^{+}-\mathrm{ClO}_{4}^{-}}^{(0)}$ & 15 \\
\hline P3 & $\begin{array}{l}\mathrm{NpO}_{2} \mathrm{OH}(\mathrm{am}) \\
\mathrm{NpO}_{2} \mathrm{OH} \text { (aged); } \\
\mathrm{NpO}_{2}^{+} \mathrm{OH}^{-}\end{array}$ & $0.1,1,3 \mathrm{M} \mathrm{NaClO} 4$ & sol & $\begin{array}{l}\left(\mu_{4}^{\circ} / \mathrm{RT}\right)_{\mathrm{NpO}_{2} \mathrm{OH}(\mathrm{aq})} \\
\left(\mu_{4}^{0} / \mathrm{RT}\right)_{\mathrm{NpO}_{2}(\mathrm{OH} \vec{k} \cdot} \\
\left(\mu_{4}^{0} / \mathrm{RT}\right)_{\mathrm{NpO}_{2} \mathrm{OH}(\mathrm{am})} ; \\
\left(\mu_{\mathrm{f}}^{0} / \mathrm{RT}\right)_{\mathrm{NpO}_{2} \mathrm{OH}(\text { aged })}\end{array}$ & $\begin{array}{l}17 \\
18\end{array}$ \\
\hline$\overline{P 4}$ & $\mathrm{NpO}_{2}^{+}-\mathrm{CO}_{3}^{2-}$ & $\begin{array}{l}0.1,1.0,3.0,5.0 \mathrm{M} \mathrm{NaClO}_{4} \\
\log \left(\mathrm{m}_{\mathrm{CO}_{3}^{2-}}^{2-<\sim-5}\right.\end{array}$ & sol & $\left(\mu_{4}^{0} / \mathrm{RT}\right)_{\mathrm{NaNpO}_{2} \mathrm{CO}_{3}(\mathrm{~s})}$ & $\begin{array}{l}15 \\
20, \\
21\end{array}$ \\
\hline P5 & $\mathrm{NpO}_{2}^{+}-\mathrm{CO}_{3}^{2-}$ & $\begin{array}{l}0.1,1.0,3.0,5.0 \mathrm{M} \mathrm{NaClO} \\
\sim-5<\log \left(\mathrm{m}_{\mathrm{CO}_{3}^{2-}}^{2-}<--2.5\right.\end{array}$ & sol & 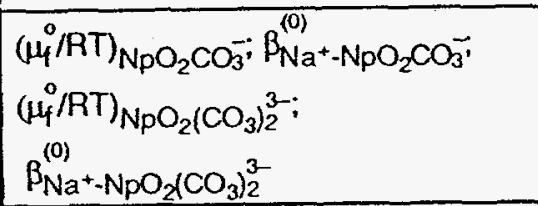 & $\begin{array}{l}15, \\
20, \\
21\end{array}$ \\
\hline P6 & $\mathrm{NpO}_{2}^{+}-\mathrm{CO}_{3}^{2-}$ & $0.05-1.6 \mathrm{M} \mathrm{Na}_{2} \mathrm{CO}_{3}$ & sol & 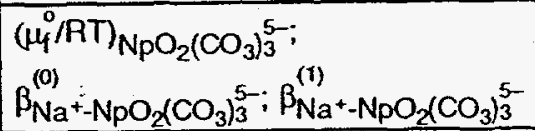 & 14 \\
\hline
\end{tabular}

\begin{tabular}{|c|c|c|c|c|c|}
\hline & System & Medium & Type & Parameters Tested & Ref. \\
\hline T1 & $\mathrm{NpO}_{2}^{+}-\mathrm{Cl}^{-}-\mathrm{ClO}_{4}^{-}$ & $\begin{array}{l}1=5.0 \mathrm{M} \mathrm{NaCVNaClO} \\
\text { mixtures }\end{array}$ & extr & 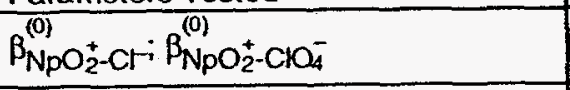 & 15 \\
\hline $\mathrm{T} 2$ & $\mathrm{NpO}_{2}^{+}-\mathrm{Cl}-\mathrm{ClO}_{4}^{-}$ & $\begin{array}{l}\mathrm{I}=2.0 \mathrm{M} \mathrm{NaClNaClO} \\
\text { mixtures }\end{array}$ & extr & 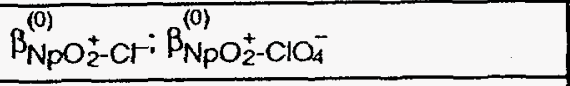 & 16 \\
\hline T3 & $\begin{array}{l}\mathrm{NpO}_{2} \mathrm{OH}(\text { am) } \\
\mathrm{NpO}_{2} \mathrm{OH} \text { (aged) }\end{array}$ & $0.1,1,3 \mathrm{M} \mathrm{NaClO} 4$ & sol & $\beta_{\mathrm{NpO}_{2}^{+}-\mathrm{ClO}_{4}^{-}}^{(0)}$ & $\begin{array}{l}17 \\
18 \\
\end{array}$ \\
\hline T4 & $\begin{array}{l}\mathrm{NpO}_{2} \mathrm{OH}(\mathrm{am}) \\
\text { solubility }\end{array}$ & $0.3-5.6 \mathrm{~m} \mathrm{NaCl}$ & sol & $\beta_{\mathrm{NpO}_{2}^{+}-\mathrm{Cr}}^{(0)}\left(\mu_{4}^{0} / \mathrm{RT}\right)_{\mathrm{NpO}_{2} \mathrm{OH}(\mathrm{am})}$ & $\begin{array}{l}\text { this } \\
\text { work }\end{array}$ \\
\hline T5 & $\mathrm{NpO}_{2}^{+}-\mathrm{CO}_{3}^{2-}$ & $\begin{array}{l}0.1,1.0,3.0,5.0 \mathrm{M} \mathrm{NaClO} \\
4 \\
\log \left(\mathrm{m}_{\mathrm{CO}_{3}^{2}}^{2-}<\sim-5\right.\end{array}$ & sol & $\beta_{\mathrm{NpO}_{2}^{+}-\mathrm{ClO}_{4}^{-}}^{(0)}$ & $\begin{array}{l}15 \\
20 \\
21 \\
\end{array}$ \\
\hline T6 & $\mathrm{NpO}_{2}^{+}-\mathrm{CO}_{3}^{2-}$ & $1 \mathrm{M} \mathrm{NaClO}_{4}$ & extr & 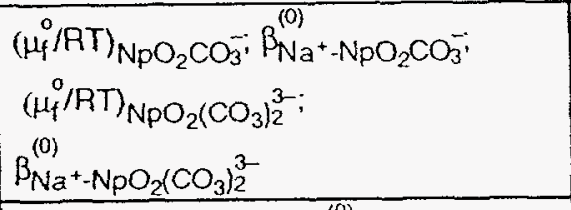 & 19 \\
\hline$\pi 7$ & $\mathrm{NpO}_{2}^{+}-\mathrm{CO}_{3}^{2-}$ & $\begin{array}{l}0.1,1.0,3.0,5.0 \mathrm{M} \mathrm{NaClO}_{4} \\
\log \left(\mathrm{m}_{\mathrm{CO}_{3}^{2-}}\right)>-2.5\end{array}$ & sol & 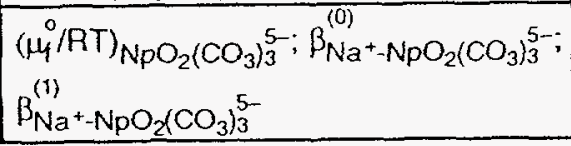 & $\begin{array}{l}15 \\
20 \\
21\end{array}$ \\
\hline
\end{tabular}

\begin{tabular}{|l|l|l|l|l|l|}
\hline & System & Medium & Type & Overall Comparison & Ref. \\
\hline & $\mathrm{NpO}_{2}^{+}-\mathrm{CO}_{3}^{2-}$ & $5.0 \mathrm{M} \mathrm{NaCl}$ & sol & for comparison with model & 15 \\
\hline $\begin{array}{l}\mathrm{Np}(\mathrm{V}) \text { in complex } \\
\text { synthetic brines }\end{array}$ & 0.8 and 3.0 lonic Strength & sol & for comparison with model & $\begin{array}{l}\text { this } \\
\text { work }\end{array}$ \\
\hline
\end{tabular}


Table II. Fixed parameters for model fitting (from Harvie et al. ${ }^{4}$ unless otherwise noted).

\begin{tabular}{|c|c|c|c|c|c|}
\hline \multicolumn{6}{|c|}{ Standard Chemical Potentials } \\
\hline Species & $\mu_{f}^{\circ} / R T$ & Species & $\mu_{f}^{\circ} / R T$ & Species & $\mu_{f}^{0} / \mathrm{RT}$ \\
\hline $\mathrm{H}_{2} \mathrm{O}$ & -95.6635 & $\mathrm{ClO}_{4}^{-}$ & $-73.805[24]$ & $\mathrm{HCO}_{3}^{-}$ & -236.751 \\
\hline $\mathrm{H}^{+}$ & 0.0 & $\mathrm{Cr}^{-}$ & -52.955 & $\mathrm{CO}^{2-}$ & -212.944 \\
\hline $\mathrm{OH}-$ & -63.435 & $\mathrm{CO}_{2}(\mathrm{aq})$ & -155.68 & $\mathrm{NpO}_{2}^{+}$ & $-369.127[25]$ \\
\hline $\mathrm{Na}^{+}$ & -105.651 & & & & \\
\hline
\end{tabular}

\begin{tabular}{|c|c|c|c|c|c|c|c|}
\hline \multicolumn{8}{|c|}{ Binary Electrolyte Parameters } \\
\hline & $\beta^{(0)}$ & $\beta^{(1)}$ & $C^{\phi}$ & & $\beta^{(0)}$ & $\beta^{(1)}$ & $C^{\phi}$ \\
\hline $\mathrm{Na}^{+}-\mathrm{OH}^{-}$ & 0.0864 & 0.253 & 0.0044 & $\mathrm{Na}^{+}-\mathrm{Cr}^{-}$ & 0.0765 & 0.2664 & 0.00127 \\
\hline $\mathrm{Na}^{+}-\mathrm{ClO}_{4}^{-}$ & $\begin{array}{l}0.0554 \\
{[26]}\end{array}$ & $\begin{array}{l}0.2755 \\
{[26]}\end{array}$ & $\begin{array}{l}-0.00118 \\
{[26]}\end{array}$ & $\mathrm{H}^{+}-\mathrm{Cr}$ & 0.1775 & 0.2945 & 0.0008 \\
\hline $\mathrm{Na}^{+}-\mathrm{CO}_{3}^{2-}$ & 0.0399 & 1.389 & 0.0044 & $\mathrm{H}^{+}-\mathrm{ClO}_{4}^{-}$ & $\begin{array}{l}0.1747 \\
{[26]}\end{array}$ & $\begin{array}{l}0.2931 \\
{[26]}\end{array}$ & $\begin{array}{l}0.00819 \\
{[26]}\end{array}$ \\
\hline $\mathrm{Na}^{+}-\mathrm{HCO}_{3}^{-}$ & 0.0277 & 0.0411 & 0 & & & & \\
\hline
\end{tabular}

\begin{tabular}{|ll|ll|ll|}
\hline \multicolumn{5}{|c|}{ Ternary Electrolyte Parameters } \\
\hline $\mathrm{Na}^{+}-\mathrm{H}^{+}$ & 0.036 & $\mathrm{Cr}^{-}-\mathrm{CO}_{3}^{2-}$ & -0.02 & $\mathrm{OH}^{-}-\mathrm{CO}_{3}^{2-}$ & 0.10 \\
$\mathrm{Na}^{+}-\mathrm{H}^{+}-\mathrm{ClO}_{4}^{-}$ & $-0.016[26]$ & $\mathrm{Cr}^{-}-\mathrm{CO}_{3}^{2-}-\mathrm{Na}^{+}$ & 0.0085 & $\mathrm{OH}^{-}-\mathrm{CO}_{3}^{2-}-\mathrm{Na}^{+}$ & -0.017 \\
$\mathrm{Na}^{+}-\mathrm{H}^{+}-\mathrm{Cl}^{-}$ & -0.004 & $\mathrm{Cr}^{-}-\mathrm{HCO}_{3}^{-}$ & 0.03 & $\mathrm{CO}_{3}^{2-}-\mathrm{HCO}_{3}^{-}$ & -0.04 \\
$\mathrm{Cl}^{-}-\mathrm{OH}^{-}$ & -0.050 & $\mathrm{Cl}^{-}-\mathrm{HCO}_{3}^{-}-\mathrm{Na}^{+}$ & -0.015 & $\mathrm{CO}_{3}^{2-}-\mathrm{HCO}_{3}^{-}-\mathrm{Na}^{+}$ & 0.002 \\
$\mathrm{Cr}^{-}-\mathrm{OH}^{-}-\mathrm{Na}^{+}$ & -0.006 & & & & \\
\hline
\end{tabular}

\begin{tabular}{|ll|ll|}
\hline \multicolumn{4}{|c|}{ Neutral lon Parameters } \\
\hline $\mathrm{Na}^{+}-\mathrm{CO}_{2}(\mathrm{aq})$ & 0.100 & $\mathrm{Cl}^{-}-\mathrm{CO}_{2}(\mathrm{aq})$ & -0.005 \\
\hline
\end{tabular}

Table III. Standard chemical potentials for neptunyl species calculated in this paper

\begin{tabular}{|c|c|c|c|}
\hline Species & $\mu_{4}^{\circ} / \mathrm{RT}$ & Species & $\mu_{4}^{\circ} / \mathrm{RT}$ \\
\hline $\mathrm{NpO}_{2} \mathrm{OH}(\mathrm{am})$ & -452.642 & $\mathrm{NaNpO}_{2} \mathrm{CO}_{3}(\mathrm{~s})$ & -713.707 \\
\hline $\mathrm{NpO}_{2} \mathrm{OH}$ (aged) & -454.010 & $\mathrm{NpO}_{2} \mathrm{CO}_{3}^{-}$ & -594.492 \\
\hline $\mathrm{NpO}_{2} \mathrm{OH}(\mathrm{aq})$ & -438.518 & $\mathrm{NpO}_{2}\left(\mathrm{CO}_{3}\right)_{2}^{3-}$ & -808.403 \\
\hline $\mathrm{NpO}_{2}(\mathrm{OH})_{2}^{-}$ & -505.829 & $\mathrm{NpO}_{2}\left(\mathrm{CO}_{3}\right)_{3}^{5-}$ & -1019.918 \\
\hline
\end{tabular}

Table IV. Pitzer parameters calculated in this paper

\begin{tabular}{|l|l|l|l|l|l|}
\hline$\beta_{\mathrm{NpO}_{2}^{+}-\mathrm{ClO}_{4}^{-}}^{(0)}$ & 0.312 & $\beta_{\mathrm{Na}^{+}-\mathrm{NpO}_{2} \mathrm{CO}_{3}^{-}}^{(0)}$ & 0.161 & $\beta_{\mathrm{Na}^{+}-\mathrm{NpO}_{2}\left(\mathrm{CO}_{3}\right)_{3}^{5-}}^{1.97}$ & \\
\hline$\beta_{\mathrm{NpO}_{2}^{+}-\mathrm{Cl}^{-}}^{(0)}$ & 0.169 & $\beta_{\mathrm{Na}^{+}-\mathrm{NpO}_{2}\left(\mathrm{CO}_{3}\right)_{2}^{3-}}^{(0)}$ & 0.407 & $\beta_{\mathrm{Na}^{+}-\mathrm{NpO}_{2}\left(\mathrm{CO}_{3}\right)_{3}^{5-}}^{(1)}$ & $16-$ \\
\hline
\end{tabular}


$\mathrm{NpO}_{2} \mathrm{OH}$ (aged) is lower than $\mathrm{NpO} \mathrm{O}_{2} \mathrm{OH}(\mathrm{am})$, and the system shows amphoteric behavior. These data can be interpreted using the solubility and hydrolysis reactions

$$
\begin{aligned}
& \mathrm{NpO}_{2} \mathrm{OH}(\mathrm{am}) \leftrightarrow \mathrm{NpO}_{2}^{+}+\mathrm{OH}^{-} \\
& \mathrm{NpO}_{2} \mathrm{OH}(\text { aged }) \leftrightarrow \mathrm{NpO}_{2}^{+}+\mathrm{OH}^{-} \\
& \mathrm{NpO}_{2}^{+}+\mathrm{OH}^{-} \leftrightarrow \mathrm{NpO}_{2} \mathrm{OH}(\mathrm{aq}) \\
& \mathrm{NpO}_{2}^{+}+2 \mathrm{OH}^{-} \leftrightarrow \mathrm{NpO}_{2}(\mathrm{OH})_{2}^{-}
\end{aligned}
$$

Because the solubility was determined in relatively high $\mathrm{NaClO}_{4}$ concentrations, the data interpretation requires the ion interaction parameters for $\mathrm{NpO}_{2}^{+}-\mathrm{ClO}_{4}^{-}$, calculated in the previous section. Although these data, Fig. 2, represent two solid phases with different standard chemical potentials, the hydrolysis behavior is independent of the solid phase and thus must be the same for both. The "low" $\mathrm{pH}$ data $\left(\log \left(\mathrm{m}_{\mathrm{bH}^{-}}\right)<-3\right)$ were used to determine standard chemical potentials for the solid phases in Reactions 1 and 2, see Table III. The agreement between the model and the solubility data at low $\mathrm{pH}$ values as a function of $\mathrm{NaClO}_{4}$ concentration, Fig. 2, indicates that the $\beta^{(0)}$ value determined from solvent extraction data is reliable. The standard chemical potential for $\mathrm{NpO}_{2}(\mathrm{OH})_{2}^{-}$was fitted from the high $\mathrm{m}_{\mathrm{OH}^{-}}$values where this species dominates; the standard chemical potential for $\mathrm{NpO}_{2} \mathrm{OH}(\mathrm{aq})$ was fitted from the intermediate $\mathrm{m}_{\mathrm{OH}^{-}}$values, also in Table III. No ion interaction parameters between hydrolysis species and either $\mathrm{Na}^{+}$or $\mathrm{ClO}_{4}^{-}$were required.

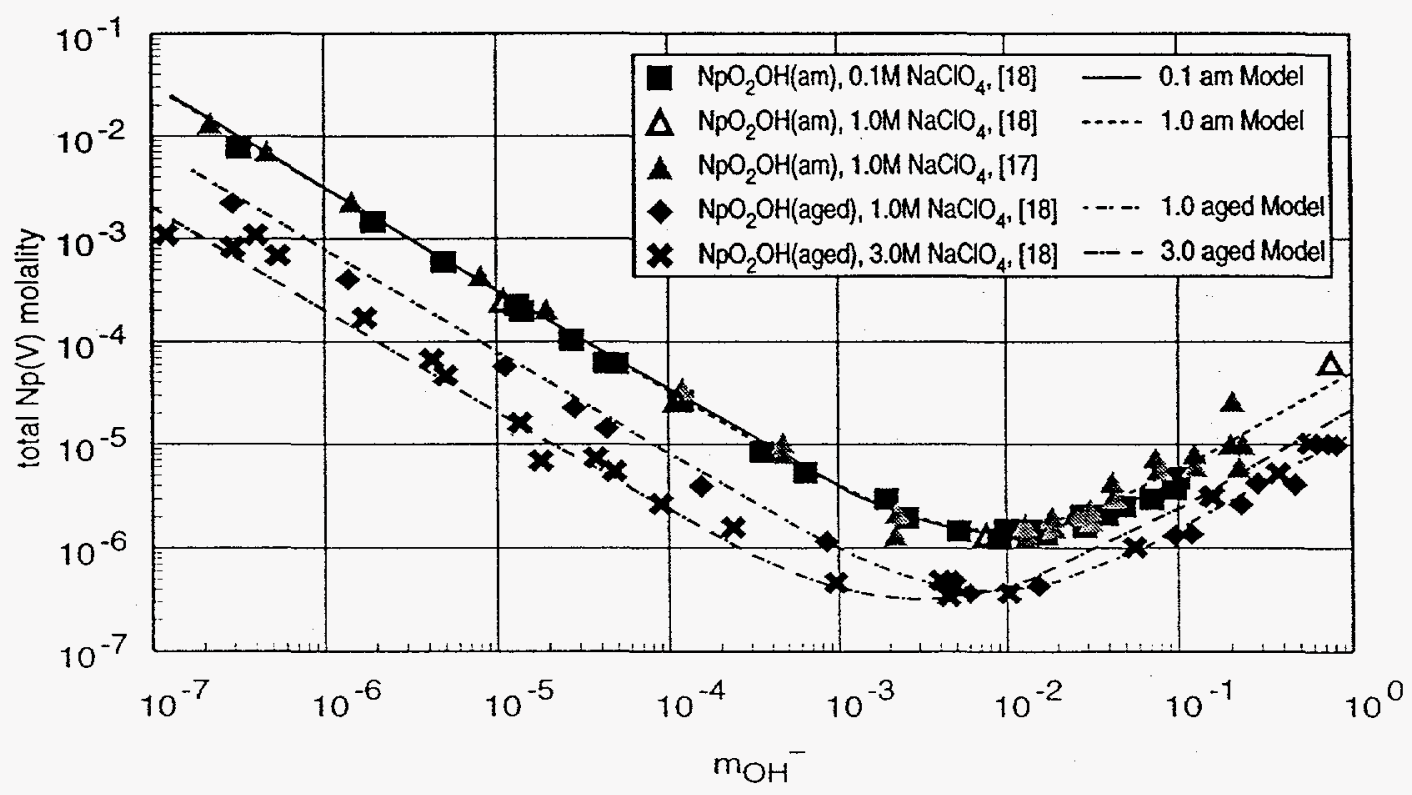

Figure 2. Data 17,18 used to calculate standard chemical potentials for neptunijum hydroxide solid and hydrolysis species, and to build confidence in the value for $\mathrm{B}_{\mathrm{NpO}_{2}^{+}}^{+} \mathrm{ClO}_{4}^{-}$

The reliability of the standard chemical potential for $\mathrm{NpO}_{2} \mathrm{OH}(\mathrm{am})$ and the Pitzer ion interaction parameter for $\mathrm{NpO}_{2}^{+}$with $\mathrm{Cl}^{-}$determined above were tested using data that we measured for the solubility of $\mathrm{NpO}_{2} \mathrm{OH}(\mathrm{am})$ in $\mathrm{NaCl}$ solutions; see the Appendix for details. Good agreement between the measured and predicted solubility of $\mathrm{NpO}_{2} \mathrm{OH}(\mathrm{am})$ in $\mathrm{NaCl}$ solutions (Fig. $3)$ indicates that the values for $\left(\mu_{\mathrm{f}}^{\mathrm{o}} / \mathrm{RT}\right)_{\mathrm{NpO}_{2} \mathrm{OH}(\mathrm{am})}$ and $\mathrm{B}_{\mathrm{NpO}}^{(\mathrm{O})}{ }_{2}^{+}-\mathrm{Cl}^{-}$are reliable. 

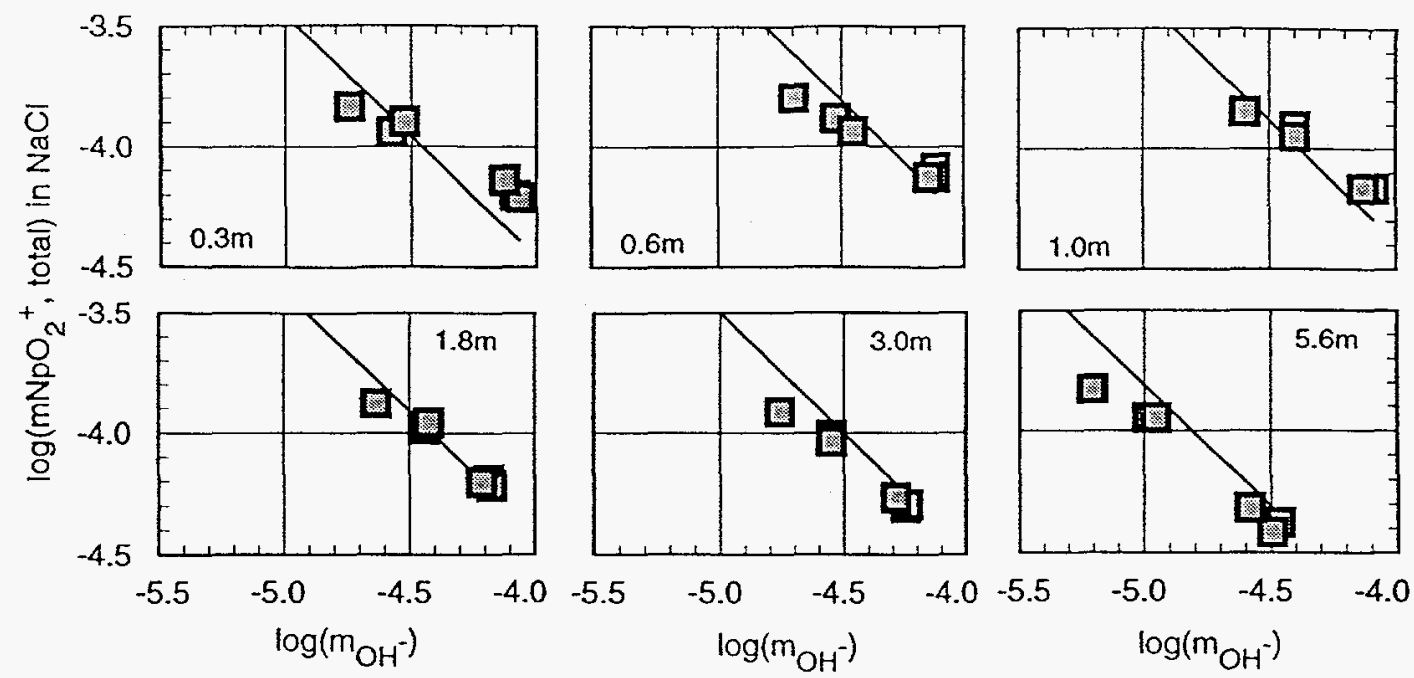

Figure 3. Experimental data and model predictions of $\mathrm{NpO}_{2} \mathrm{OH}(\mathrm{am})$ solubility in $\mathrm{NaCl}$ solutions.

Standard Chemical Potentials for $\mathrm{NaNpO}_{2} \mathrm{CO}_{3}(\mathrm{~s}), \mathrm{NpO}_{2} \mathrm{CO}_{3}^{-}$, and $\mathrm{NpO}_{2}\left(\mathrm{CO}_{3}\right)_{2}^{3-}$; and Ion Interactions for $\mathrm{Na}^{+}-\mathrm{NpO}_{2} \mathrm{CO}_{3}^{-}$and $\mathrm{Na}^{+}-\mathrm{NpO}_{2}\left(\mathrm{CO}_{3}\right)_{2}^{3-}$ (Data Series P4, P5; T5, T6)

Neptunyl complexation with carbonate and the solubility of $\mathrm{NaNpO}_{2} \mathrm{CO}_{3}(\mathrm{~s})$ in several media under different conditions have been reported by various authors. ${ }^{14,15,19,20,21}$ These data were used to develop and test the model for neptunyl complexation with carbonate. The bulk of the data was taken at constant $\mathrm{CO}_{2}(\mathrm{~g})$ pressure in $0.1,1.0,3.0$, and $5.0 \mathrm{M} \mathrm{NaClO}$ ( Neck et al. $^{15}$; Kim et al. ${ }^{20}$ ), although Maya ${ }^{21}$ reported solubility both in solutions with fixed total inorganic carbon and with fixed $\mathrm{CO}_{2}(\mathrm{~g})$ partial pressure. During analysis, a discrepancy of up to $1.1 \mathrm{log}$ units was noted in some of the data 15,20 between the reported hydrogen ion and carbonate concentrations and the Harvie-Møller-Weare model ${ }^{4}$ predictions. This may indicate the need for improved models describing the solubility of $\mathrm{CO}_{2}(\mathrm{~g})$ in $\mathrm{NaClO}_{4}$ media, or a lack of equilibrium between the $\mathrm{CO}_{2}$ in the gas and aqueous phases. This discrepancy rendered it unrealistic to use $\mathrm{pH} / \mathrm{pcH}$ values and fixed $\mathrm{CO}_{2}(\mathrm{~g})$ pressures for parameterization, thus the reported carbonate concentrations were considered primary data. This interpretation is reasonable because the data of Maya, ${ }^{21}$ in which $\mathrm{Np}(\mathrm{V})$ solubilities were measured both for fixed solution composition and solutions in equilibrium with a gas phase, overlie the data from Kim et al. ${ }^{20}$ for $1.0 \mathrm{M} \mathrm{NaClO}$ solutions. These data, plotted in Fig. 4, were used to calculate thermodynamic parameters for $\mathrm{NaNpO}_{2} \mathrm{CO}_{3}(\mathrm{~s}), \mathrm{NpO}_{2} \mathrm{CO}_{3}^{-}$, and $\mathrm{NpO}_{2}\left(\mathrm{CO}_{3}\right)_{2}^{3-}$. The behavior of the neptunyl ion in the presence of carbonate can be described by the reactions

$$
\begin{aligned}
& \mathrm{NaNpO}_{2} \mathrm{CO}_{3}(\mathrm{~s}) \leftrightarrow \mathrm{Na}^{+}+\mathrm{NpO}_{2}^{+}+\mathrm{CO}_{3}^{2-} \\
& \mathrm{NpO}_{2}^{+}+\mathrm{CO}_{3}^{2-} \leftrightarrow \mathrm{NpO}_{2} \mathrm{CO}_{3}^{-} \\
& \mathrm{NpO}_{2}^{+}+2 \mathrm{CO}_{3}^{2-} \leftrightarrow \mathrm{NpO}_{2}\left(\mathrm{CO}_{3}\right)_{2}^{3-} \\
& \mathrm{NpO}_{2}^{+}+3 \mathrm{CO}_{3}^{2-} \leftrightarrow \mathrm{NpO}_{2}\left(\mathrm{CO}_{3}\right)_{3}^{5-}
\end{aligned}
$$

Data for $\log \left(\mathrm{m}_{\mathrm{CO}_{3}^{2-}}\right)<-5$, where Reaction 5 dominates, were used to determine the standard chemical potential of the solid, and to test the value for $\mathrm{BNpO}_{2}^{+} \cdot \mathrm{ClO}_{4}^{-}$. The mono- and biscarbonato species dominate in the intermediate carbonate concentration range, $-5<\log \left(\mathrm{m}_{\mathrm{CO}}^{2-}\right)<$

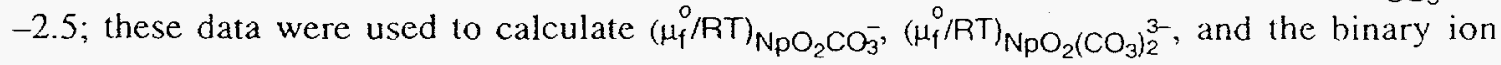




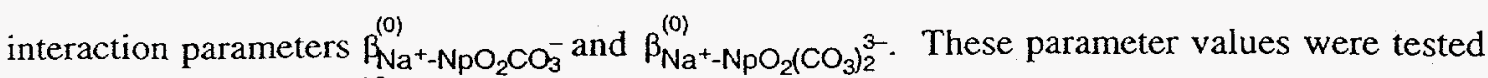
against extraction data, ${ }^{19}$ producing the favorable comparison shown in Fig. 5 . The region where $\log \left(\mathrm{m}_{\mathrm{CO}_{3}^{2-}}\right)>-2.5$ is discussed in the following section.

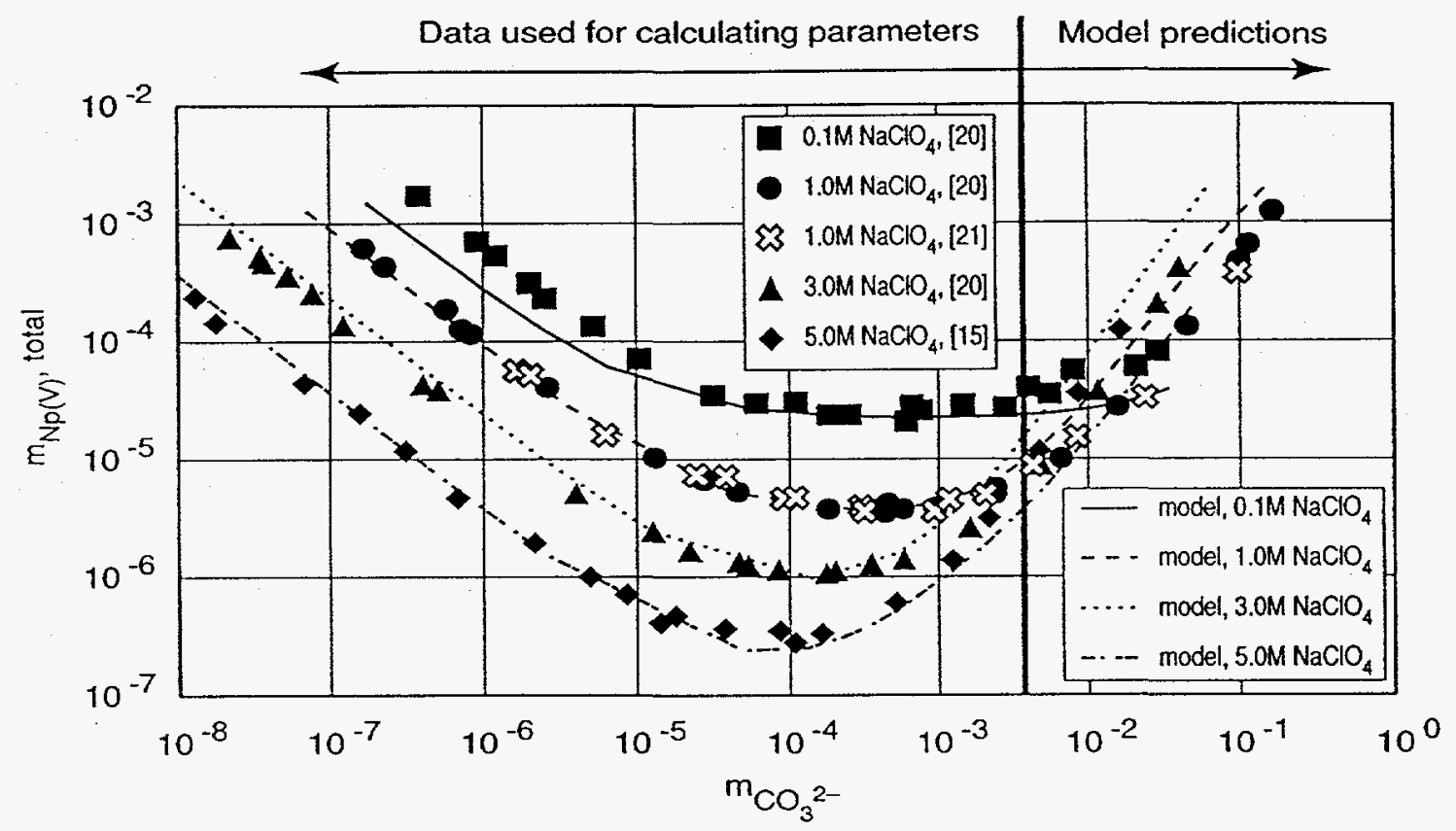

Figure 4. Data $15,20,21$ for parameterizing/testing the model for neptunyl-carbonate reactions.

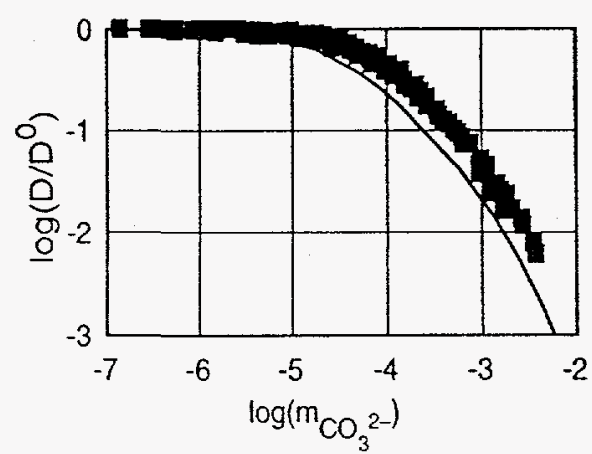

Figure 5.Comparison of model with data ${ }^{19}$ for extraction of neptunyl carbonate complexes in $1.0 \mathrm{M} \mathrm{NaCO}_{4}$
Standard Chemical Potential for $\mathrm{NpO}_{2}\left(\mathrm{CO}_{3}\right)_{3}^{5-}$ and $\mathrm{Na}^{+}-\mathrm{NpO}_{2}\left(\mathrm{CO}_{3}\right)_{3}^{5-}$ Ion Interactions (Data Series P6; T7)

Calculating thermodynamic parameters for the neptunyl triscarbonato species requires data extending to high carbonate concentration. Ueno and Saito ${ }^{14}$ examined the solubility of $\mathrm{NaNpO}_{2} \mathrm{CO}_{3}(\mathrm{~s})$ in 0.05 to $1.6 \mathrm{M} \mathrm{N} \mathrm{a}_{2} \mathrm{CO}_{3}$ solutions. Although $\mathrm{Na}_{3} \mathrm{NpO}_{2}\left(\mathrm{CO}_{3}\right)_{2}(\mathrm{~s})$ has been reported to be the stable phase in these high concentration ranges, ${ }^{11}$ $\mathrm{NaNpO}_{2} \mathrm{CO}_{3}$ (s) was most probably the metastable equilibrium solid over the reported one to two day equilibration period. Assuming the $\mathrm{NaNpO}_{2} \mathrm{CO}_{3}(\mathrm{~s})$ solid phase, and using the thermodynamic parameters

previously developed in this paper, these solubility data are well represented by the triscarbonato

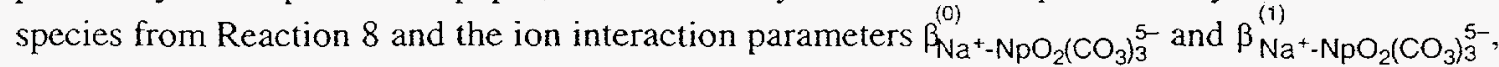
as shown by the comparison in Fig. 6. The predicted solubilities of $\mathrm{NaNpO}_{2} \mathrm{CO}_{3}(\mathrm{~s})$ in $\mathrm{NaClO}_{4}$ solutions are consistent with the data sets given in Fig. 4 for $\log \left(\mathrm{m}_{\mathrm{CO}_{3}^{2-}}\right)>-2.5$, where the species $\mathrm{NpO}_{2}\left(\mathrm{CO}_{3}\right)_{3}^{5-}$ is also important. Thus the solid phase identified by Ueno and Saito is supported, and values for the neptunyl triscarbonato complex can be calculated from these data. Although $\mathrm{NpO}_{2}\left(\mathrm{CO}_{3}\right)_{2}^{3-}$ never dominates under the conditions of Fig. 6 , this species is dominant under the conditions of Fig. 4 for $-4<\log \left(\mathrm{m}_{\mathrm{CO}_{3}^{2-}}\right)<-2$. 


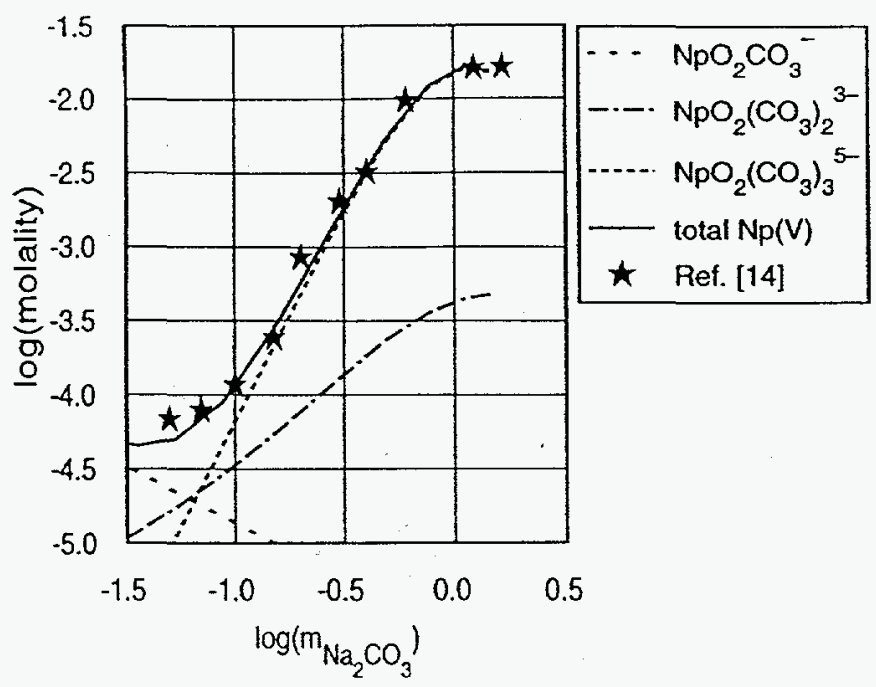

Figure 6. Data ${ }^{14}$ and model fit of $\mathrm{NaNpO}_{2} \mathrm{CO}_{3}(\mathrm{~s})$ solubility in $\mathrm{Na}_{2} \mathrm{CO}_{3}$ solutions.

\section{DISCUSSION OF MODEL AND PARAMETERS}

The model developed here is a comprehensive, unified description of $\mathrm{Np}(\mathrm{V})$ solubility behavior in $\mathrm{Na}-\mathrm{CO}_{3}-\mathrm{Cl}-\mathrm{ClO}_{4}$ media. The model is based on the formation of important aqueous species and binary cation-anion interactions between neptunyl species and bulk solution ions. The model is a synthesis of, and explains, nine different data sets representing two types of experiments. Model species and parameters are summarized in Tables III and IV. The

thermodynamic equilibrium constants for the hydrolysis system, Reactions 1 through 4, are $\log \mathrm{K}_{\mathrm{sp}}=-8.72, \log \mathrm{K}_{\mathrm{sp}}=-9.32, \log \beta_{101}=2.58$, and $\log \beta_{102}=4.27$, respectively; the thermodynamic equilibrium constants for the carbonate system, Reactions 5 through 8 , are $\log \mathrm{K}_{\mathrm{sp}}=-11.3, \log \beta_{101}=5.39, \log \beta_{102}=5.81$, and $\log \beta_{103}=5.19$, respectively. Comparison with parameter values reported for 1-1, 3-1, and 5-1 electrolytes ${ }^{22}$ show that all the values for activity coefficient parameters are reasonable, e.g., our calculated value for the 5:1 electrolyte

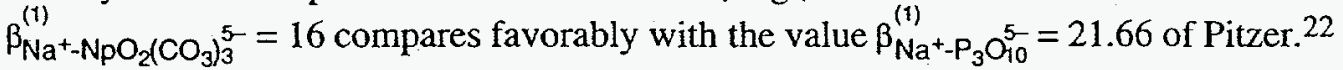

\section{Testing The Predictive AbILITy of THE Model}

Although the model explains many simple data sets, additional testing of the model is necessary to generate confidence that the model can predict total dissolved $\mathrm{Np}(\mathrm{V})$ concentrations in complex natural systems. Two comparisons are given here to provide some confidence in this model, and indicate some directions for future work.

Most of the data used to develop this model were obtained in $\mathrm{NaClO}_{4}$ media; little data in $\mathrm{NaCl}$ media were available. However, in natural systems, $\mathrm{NaCl}$ is likely to be the dominant electrolyte, and thus it is essential to establish the applicability of this model to sodium chloride solutions. Then, is it possible that the solubility behavior of $N p(V)$ in more complex natural brines, e.g., containing small amounts of $\mathrm{K}-\mathrm{Mg}-\mathrm{Ca}-\mathrm{SO}_{4}$, can be approximated by this model. These points are tested against additional experimental data.

The solubility of $\mathrm{NaNpO}_{2} \mathrm{CO}_{3}(\mathrm{~s})$ is reported ${ }^{15}$ as a function of $\mathrm{pH}$ in $5 \mathrm{M} \mathrm{NaCl}$ at constant $\log \mathrm{PCO}_{2}$ (g) of -3.5 . In contrast with these authors' similar data in $\mathrm{NaClO}_{4}$, the reported hydrogen ion and carbonate concentrations are consistent with the Harvie-Møller-Weare model. ${ }^{4}$ Thus the system can be modeled as open to the gas phase. A comparison of these data with the model developed above is presented in Fig. 7 along with calculated species concentrations. The model follows the trend of the data quite well, especially for high carbonate concentrations, but is offset for lower carbonate concentrations, particularly in the region where the mono- and biscarbonato species dominate. Although this may indicate that additional species are necessary to describe this system, there was no need to invoke neptunyl chloride species to describe the simpler experimental systems above. Possible reasons for the discrepancy between the observed and calculated concentrations, include: (1) the assumption that carbonate speciation in concentrated 
sodium perchlorate solutions can be described without any carbonate, bicarbonate, or carbonic acid ion interaction parameters with perchlorate may be poor, (2) the standard chemical potential may be different for this solid phase; (3) additional specific ion interaction parameters, e.g., $\mathrm{NpO}_{2}^{+}-\mathrm{Na}^{+}-\mathrm{Cl}^{-}$or $\mathrm{NpO}_{2} \mathrm{CO}_{3}^{-}-\mathrm{Cl}^{-}$, may be required; or (4) equilibrium may not have been attained. Additional experiments at different $\mathrm{NaCl}$ concentrations in $\mathrm{NaClNa}_{2} \mathrm{CO}_{3}$ media are needed to refine the values for ion interaction parameters for this system.

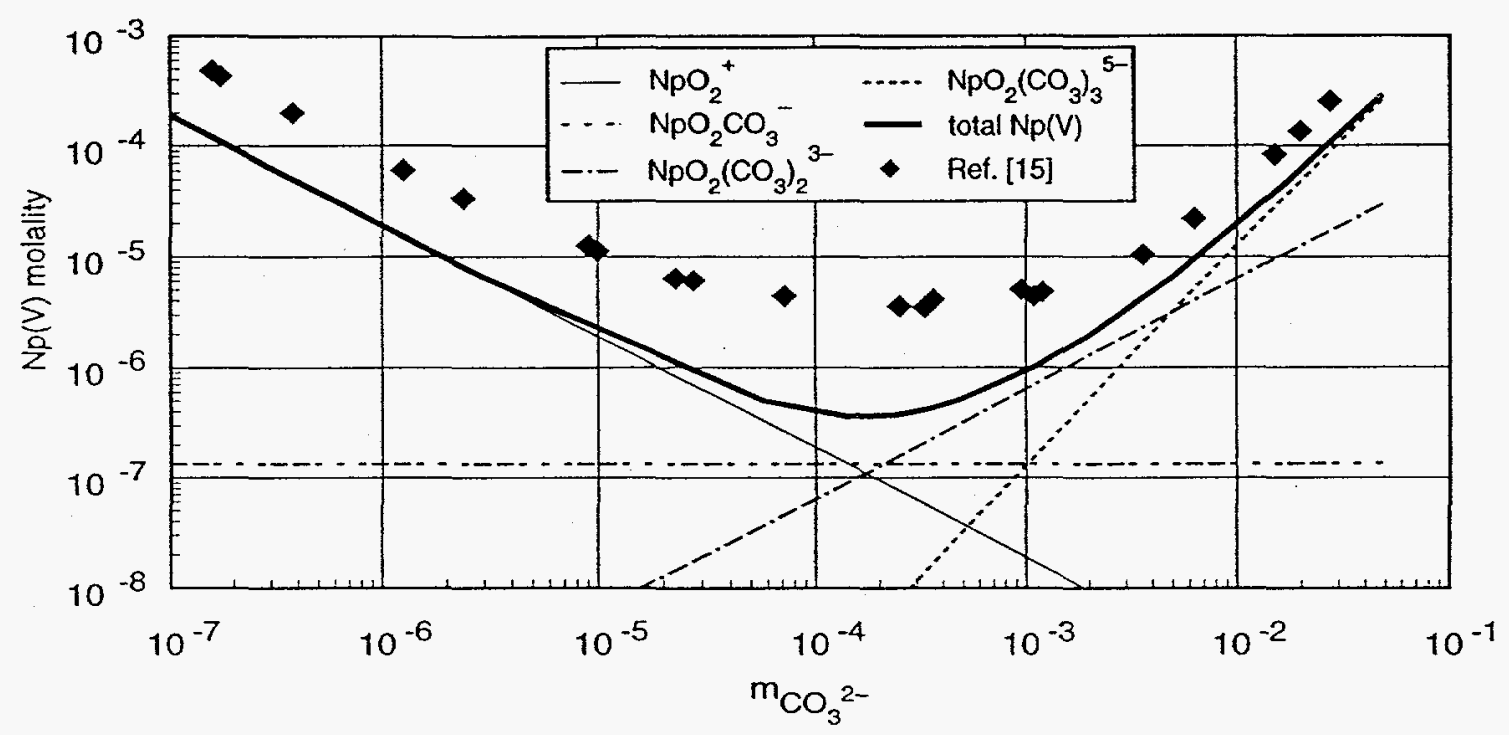

Figure 7. Comparison of model with $\mathrm{NaNpO}_{2} \mathrm{CO}_{3}(\mathrm{~s})$ solubility data 15 in $5 \mathrm{M} \mathrm{NaCl}$.

A further test of this model is comparison with solubility measurements in complex synthetic brines. Oversaturation experiments with ${ }^{237} \mathrm{~Np}(\mathrm{~V})$ were conducted in the brines AISinR and $\mathrm{H}-17$, with molal concentrations: $\mathrm{Na}^{+}(0.64,2.5), \mathrm{K}^{+}(0.0082,0.032), \mathrm{Mg}^{2+}(0.022,0.078)$, $\mathrm{Ca}^{2+}(0.017,0.031), \mathrm{Cl}^{-}(0.58,2.6), \mathrm{SO}_{4}^{2-}(0.080,0.080), \mathrm{B}(0.0028,0.0042), \mathrm{Br}^{-},(0,0.0010)$; with $\mathrm{P}_{\mathrm{CO}_{2}}$ (g) as 0.0019 and 0.0028 atm, respectively. These ongoing experiments are similar to others conducted with $\mathrm{Pu}$ in these same brines. ${ }^{23}$ Sufficient amounts of $\mathrm{Np}(\mathrm{V})$ were added to cause oversaturation and precipitation of a neptunium solid phase. The operational hydrogen ion concentration was controlled within \pm 0.1 units, and the aqueous neptunium concentration was monitored. Approximate steady-state aqueous concentration were reached after about 400 days. The solid phases were characterized by X-ray diffraction as $\mathrm{NaNpO}_{2} \mathrm{CO}_{3}(\mathrm{~s})$. These brines are predominantly sodium chloride, so previous electrode titrations, as discussed in the Appendix, were used as $\mathrm{pH} / \mathrm{pcH}$ calibrations. The measured total dissolved $\mathrm{Np}(\mathrm{V})$ concentration in AISinR Brine at $-\log \left(\mathrm{m}_{\mathrm{H}^{+}}\right)=7.7 \pm 0.2$ is $2 \times 10^{-6}$ molal; the model predicts $6 \times 10^{-6}$ to $2 \times 10^{-5}$ molal. The measured total dissolved $\mathrm{Np}(\mathrm{V})$ concentration in $\mathrm{H}-17$ Brine at $-\log \left(\mathrm{m}_{\mathrm{H}^{+}}\right)=7.8 \pm 0.2$ is $1 \times 10^{-6}$ molal; the model predicts $2 \times 10^{-6}$ to $3 \times 10^{-6}$ molal. The comparison is very good, with an order of magnitude or less difference between measured and calculated values. Although more data in complex brines are required to support the model, this work suggests the building block approach will prove successful for predicting dissolved $\mathrm{Np}(\mathrm{V})$ concentrations in complex brines.

\section{CONCluding REMARKS}

The $N p(V)$ solubility model developed here explains many different data sets from different types of experiments. As such, it appears to be robust and may be usable to obtain order-of-magnitude estimates of neptunium solubility in predominantly $\mathrm{NaCl}$ groundwaters. 
Additional experimental measurement of $\mathrm{Np}(\mathrm{V})$ chemistry in $\mathrm{NaCl} / \mathrm{Na}_{2} \mathrm{CO}_{3}$ media would allow refinement of the model and improve the predictive ability in high chloride systems.

\section{APPENDIX}

Green $\mathrm{NpO}_{2} \mathrm{OH}(\mathrm{am})$ was synthesized ${ }^{17}$ and added to $0.3,0.6,1.0,1.8,3.0$, and $5.6 \mathrm{~m} \mathrm{NaCl}$ solutions and allowed to react for 37 days. Experiments, including solution preparations, were performed in an argon atmosphere glove box using freshly distilled, deionized water to avoid introduction of carbon dioxide. No conversion to $\mathrm{NpO}_{2} \mathrm{OH}$ (aged) was noted, although this conversion was seen in concentrated $\mathrm{NaClO}_{4}$ within this time span ${ }^{17}$. Phases were separated by filtering aliquots of solution through presaturated $4.1 \mathrm{~nm}$ filters (Amicon Corp., Danvers, MA). Aqueous neptunium concentrations were determined by $\gamma$-pulse height analysis of the $29.38 \mathrm{keV}$ gamma emission from the ${ }^{237} \mathrm{~Np}$ in the supernatant. Hydrogen ion concentrations were measured using a Ross combination pH electrode (Orion Research Inc., Boston, MA) at the time of each assay. The operational $\mathrm{pH}$ read by the glass electrode was related to the actual proton concentration in each $\mathrm{NaCl}$ solution by earlier potentiometric titration of standardized solutions of $\mathrm{HCl}$ with $\mathrm{NaOH}$, both adjusted to the desired $\mathrm{NaCl}$ concentration.

\section{ACKNOWLEDGMENTS}

The authors gratefully acknowledge Gregory R. Choppin, David L. Clark, Andrew R. Felmy, and Dhanpat Rai for the technical interaction that contributed much to the form and substance of this work. Experimental work was performed at the Lawrence Berkeley Laboratory by Philip Torretto, Traudel Prussin, Herbert B. Silber, Scott A. Carpenter, David E. Hobart, and Heino Nitsche. Robert L. Paolino digitized data where necessary. This work was supported by the United States Department of Energy under Contract DE-AC04-94AL85000. 


\section{REFERENCES}

1. Fuger, J., I.L. Khodakovsky, E:I. Sergeyeva, V.A. Medvedev, and J.D. Navratil. 1992. "Part 12. The Actinide Aqueous Inorganic Compounds," The Chemical Thermodynamics of Actinide Elements and Compounds. Eds. F.L. Oetting, V.A. Medvedev, M.H. Rand, and E.F. Westrum, Jr. Vienna, Austria: International Atomic Energy Agency.

2. Grenthe, I., J. Fuger, R.J.M. Konings, R.J. Lemire, A.B. Muller, C. Nguyen-Trung, and H. Wanner. 1992. Chemical Thermodynamics of Uranium. Eds. H. Wanner and I. Forest. New York, NY: North-Holland.

3. Pitzer, K.S. 1991. "Ion Interaction Approach: Theory and Data Correlation," Activity Coefficients in Electrolyte Solutions. 2nd ed. Ed. K.S. Pitzer. Boca Raton, FL: CRC Press. 75-154.

4. Harvie, C.E., N. Moller, and J.H. Weare. 1984. "The Prediction of Mineral Solubilities in Natural Waters: The $\mathrm{Na}-\mathrm{K}-\mathrm{Mg}-\mathrm{Ca}-\mathrm{H}-$ $\mathrm{Cl}-\mathrm{SO}_{4}-\mathrm{OH}-\mathrm{HCO}_{3}-\mathrm{CO}_{2}-\mathrm{H}_{2} \mathrm{O}$ System to $\mathrm{High}$ Ionic strengths at $25^{\circ} \mathrm{C}$," Geochimica et Cosmochimica Acta. Vol. 48, no. 4, 723-751.

5. Felmy, A.R., and J.H. Weare. 1986. "The Prediction of Borate Mineral Equilibria in Natural Waters: Application to Searles Lake, California," Geochimica et Cosmochimica Acta. Vol. 50, no. $12,2771-2783$.

6. Felmy, A.R., D. Rai, J.A. Schramke, and J.L. Ryan. 1989. "The Solubility of Plutonium Hydroxide in Dilute Solution and in High-Ionic-Strength Chloride Brines," Radiochimica Acta. Vol. 48 , no. $1 / 2,29-35$.

7. Felmy, A.R., D. Rai, and R.W. Fulton. 1990. "The Solubility of $\mathrm{AmOHCO}_{3}(\mathrm{C})$ and the Aqueous Thermodynamics of the System $\mathrm{Na}^{+}-$ $\mathrm{Am}^{3+}-\mathrm{HCO}^{34}-\mathrm{CO}_{3}^{2}-\mathrm{OH}^{-}-\mathrm{H}_{2} \mathrm{O}$," Radiochimica Acta. Vol. 50, no. 4, 193204 .

8. Felmy, A.R., D. Rai, and M.J. Mason. 1992. "The Solubility of Hydrous Thorium(IV) oxide in Chloride Media: Development of an Aqueous Ion-Interaction Model," Radiochimica Acta. Vol. 55, no. $4,177-185$.

9. Felmy, A., and D. Rai. 1992. "An Aqueous Thermodynamic Model for a High Valence 4:2 Electrolyte Thorium $\left({ }^{4}\right)$-Sulfate in the System," Journal of Solution Chemistry. Vol. 21, no. 5, 407423 .

10. Grenthe, I., and H. Wanner. 1992. Guidelines for the Extrapolation to Zero Ionic Strength. NEA-TBD-2, Revision 2. Gif-sur-Yvette, France: OECD Nuclear Energy Agency, Data Bank. (Copy on file at the sandia WIPP Central Files, Sandia National Laboratories, Albuquerque, NM.) 
11. Clark, D.L., D.E. Hobart, and M.P. Neu. 1995. "Actinide Carbonate Complexes and Their Importance in Environmental Chemistry," Chemical Reviews. Vol. 95, no. 1, 25-48.

12. Newton, T.W., and J.C. Sullivan. 1986. "Actinide Carbonate Complexes in Aqueous Solution," Handbook on the Physics and Chemistry of the Actinides.Eds.A.J. Freeman and C. Keller. New York, NY: North-Holland. Vol. 4, 387-406.

13. Harvie, C.E., J.P. Greenberg, and J.H. Weare. 1987 . "A Chemical Equilibrium Algorithm for Highly Non-Ideal Multiphase Systems: Free Energy Minimization," Geochimica et Cosmochimica Acta. Vol. 51, no. 5, 1045-1057.

14. Ueno, K., and A. Saito. 1975. "Solubility and Absorption Spectra of a Carbonato Complex of Pentavalent Neptunium," Radiochemical and Radioanalytical Letters. Vol. 22, no. 2, $127-133$.

15. Neck, V., J.I. Kim, and B. Kanellakopulos. 1994. Thermodynamisches Verhalten von Neptunium $(V)$ in Konzentrierten $\mathrm{NaCl}$ - und $\mathrm{NaClO}_{4}$-Losungen. KfK-5301. Kernforschungszentrum Karlsruhe $\mathrm{GmbH}$ : Institut für Nuklear Entsorgungstechnik, Institut für Heisse Chemie.

16. Vasudeva Rao, P.R., N.M. Gudi, S.V. Bagawde, and S.K. Patil. 1979. "The Complexing of $\mathrm{Np}(\mathrm{V})$ by Some Inorganic Ligands," Journal of Inorganic and Nuclear Chemistry. Vol. 41, 235-239.

17. Lierse, C., W. Treiber, and J.I. Kim. 1985. "Hydrolysis Reactions of Neptunium(V), "Radiochimica Acta. Vol. 38, no. 1, $27-28$.

18. Neck, V., J.I. Kim, and B. Kanellakopulos. 1992. "Solubility and Hydrolysis Behavior of Neptunium(V)," Radiochimica Acta. Vol. 56, no. 1, 25-30.

19. Inoue, Y., and O. Tochiyama. 1985. "Studies of the Complexes of Neptunium(V) with Inorganic Ligands by Solvent Extraction with Thenoyltrifluoroacetone and 1,10-Phenanthroline. I. Carbonato Complexes," Bulletin of the Chemical Society of Japan. Vol. 58, no. 2, 588-591.

20. Kim, J.I., R. Klenze, V. Neck, T. Sekine, and B. Kanellakopulos.1991. Study into the Applicability of Laboratory Data to Natural Conditions: Hydrolysis of $N p(V)$ and Np $(V)$ Complexation by Carbonate and Humate. Interim Report. RCM-01091. Garching, Germany: Technische Univ. München; Bonn: Institut für Radiochemie Bundesministerium für Forschung und Technologie.

21. Maya, L. 1983. "Hydrolysis and Carbonate Complexation of Dioxoneptunium(V) in $1.0 \mathrm{~m}$ Sodium Perchlorate at $25^{\circ} \mathrm{C}$," Inorganic Chemistry. Vol. 22, no. 14, 2093-2095. 
22. Pitzer, K.S. 1991. "Ion Interaction Approach: Theory and Data Correlation," Activity Coefficients in Electrolyte Solutions. 2nd ed. Ed. K.S. Pitzer. Boca Raton, FL: CRC Press. 101-102, 107-108.

23. Nitsche, H., K. Roberts, R. Xi, T. Prussin, K. Becraft, I. A] Mahamid, H.B. Silber, S.A. Carpenter, and R.C. Gatti. 1994. "Long Term Plutonium Solubility and Speciation Studies in a Synthetic Brine," Radiochimica Acta. Vol. 66/67, 3-8.

24. Cox, J.D., D.D. Wagman, and V.A. Medvedev. 1989. CODATA Key Values for Thermodynamics. New York, NY: Hemisphere Pub. Corp. p. 268 .

25. Fuger, J., and F.L. Oetting. 1976. The Chemical Thermodynamics of Actinide Elements and Compounds. II. The Actinide Aqueous Ions. Vienna, Austria: International Atomic Energy Agency.

26. Pitzer, K.S. 1991. "Ion Interaction Approach: Theory and Data Correlation," Activity Coefficients in Electrolyte Solutions. 2nd ed. Ed. K.S. Pitzer. Boca Raton, FL: CRC Press. p. 100, 116 . 
This page intentionally left blank. 


\section{Federal Agencies}

US Department of Energy (6)

Office of Civilian Radioactive Waste Mgmt.

Attn: Deputy Director, RW-2

Associate Director, RW-10/50

Office of Prog. \& Resources Mgmt.

Office of Contract Business Mgmt.

Director, RW-22

Analysis \& Verification Division

Associate Director, RW-30

Office of Systems \& Compliance

Associate Director, RW-40

Office of Storage \& Transportation

Director, RW-4/5

Office of Strategic Planning and

International Programs

Office of External Relations

Forrestal Building

Washington, DC 20585

US Department of Energy

Albuquerque Operations Office

Attn: National Atomic Museum Library

P.O. Box 5400

Albuquerque, NM 87185-5400

US Department of Energy

Research \& Waste Management Division

Attn: Director

P.O. Box E

Oak Ridge, TN 37831

US Department of Energy (6)

Carlsbad Area Office

Attn: V. Daub

G. Dials

M. McFadden

R. Lark

R. Bills

J. A. Mewhinney

P.O. Box 3090

Carlsbad, NM 88221-3090

US Department of Energy

Attn: E. Young

Room E-178

GAO/RCED/GTN

Washington, DC 20545
US Department of Energy

Office of Environmental Restoration and

Waste Management

Attn: J. Lytle, EM-30

Forrestal Building

Washington, DC 20585-0002

US Department of Energy (3)

Office of Environmental Restoration and

Waste Management

Attn: M. Frei, EM-34, Trevion II

Washington, DC 20585-0002

US Department of Energy

Office of Environmental Restoration and

Waste Management

Attn: S. Schneider, EM-342, Trevion II

Washington, DC 20585-0002

US Department of Energy (2)

Office of Environment, Safety \& Health

Attn: C. Borgstrom, EH-25

R. Pelletier, EH-231

Washington, DC 20585

US Department of Energy (2)

Idaho Operations Office

Fuel Processing \& Waste Mgmt. Division

785 DOE Place

Idaho Falls, ID 83402

US Environmental Protection Agency (2)

Radiation Protection Programs

Attn: M. Oge

ANR-460

Washington, DC 20460

US Nuclear Regulatory Commission

Division of Waste Management

Attn: H. Marson

Mail Stop 4-H-3

Washington, DC 20555

Boards

Defense Nuclear Facilities Safety Board

Attn: D. Winters

625 Indiana Ave. NW, Suite 700

Washington, DC 20004 
Nuclear Waste Technical Review Board (2)

Attn: Chairman

$$
\text { S. J. S. Parry }
$$

1100 Wilson Blvd., Suite 910

Arlington, VA 22209-2297

Advisory Committee on Nuclear Waste

Nuclear Regulatory Commission

Attn: R. Major

7920 Norfolk Ave.

Bethesda, MD 20814

\section{State Agencies}

Attorney General of New Mexico

P.O. Drawer 1508

Santa Fe, NM 87504-1508

Environmental Evaluation Group (3)

Attn: Library

7007 Wyoming NE

Suite F-2

Albuquerque, NM 87109

NM Energy, Minerals, and Natural

Resources Department

Attn: Library

2040 S. Pacheco

Santa Fe, NM 87505

NM Environment Department (3)

Secretary of the Environment

Attn: Mark Weidler

1190 St. Francis Drive

Santa Fe, NM 87503-0968

NM Bureau of Mines \& Mineral Resources

Socorro, NM 87801

NM Environment Department

WIPP Project Site

Attn: P. McCasland

P.O. Box 3090

Carlsbad, NM 88221

\section{Laboratories/Corporations}

Battelle Pacific Northwest Laboratories (8)

Attn: Dr. Andy R. Felmy

Environmental and Energy Sciences Division ETB-K9-77

Richland, WA 99352
Battelle Pacific Northwest Laboratories Attn: R. E. Westerman, MSIN P8-44 Battelle Blvd.

Richland, WA 99352

INTERA, Inc.

Attn: G. A. Freeze

1650 University Blvd. NE, Suite 300

Albuquerque, NM 87102

INTERA, Inc.

Attn: J. F. Pickens

6850 Austin Center Blvd., Suite 300

Austin, TX 78731

INTERA, Inc.

Attn: W. Stensrud

P.O. Box 2123

Carlsbad, NM 88221

Lawrence Berkeley Laboratory (8)

Attn: Dr. Ilham Al Mahamid

Mail Stop 70A-1115

1 Cyclotron Road

Berkeley, CA 94720

Lawrence Livermore National Laboratory (8)

Attn: Dr. Cynthia E. A. Palmer

Mail Stop L-232

P.O. Box 808

Livermore, CA 94551

Lawrence Livermore National Laboratory (8)

Attn: Kevin Roberts

Mail Stop L-396

P.O. Box 808

Livermore, CA 94551

Los Alamos National Laboratory

Attn: B. Erdal, INC-12

P.O. Box 1663

Los Alamos, NM 87544

RE/SPEC, Inc

Attn: Angus Robb

4775 Indian School NE, Suite 300

Albuquerque, NM 87110-3927

RE/SPEC, Inc

Attn: J. L. Ratigan

P.O. Box 725

Rapid City, SD 57709 
Southwest Research Institute (2)

Center for Nuclear Waste Regulatory Analysis

Attn: P. K. Nair

6220 Culebra Road

San Antonio, TX 78228-0510

Tech Reps, Inc. (4)

Attn: J. Chapman (2)

T. Peterson (2)

5000 Marble NE, Suite 222

Albuquerque, NM 87110

Westinghouse Electric Corporation (5)

Attn: Library

C. Cox

L. Fitch

B. A. Howard

R. Kehrman

P.O. Box 2078

Carlsbad, NM 88221

S. Cohen \& Associates

Attn: Bill Thurber

1355 Beverly Road

McLean, VA 22101

\section{National Academy of Sciences, WIPP Panel}

Howard Adler

Oxyrase, Incorporated

7327 Oak Ridge Highway

Knoxville, TN 37931

Ina Alterman

Board of Radioactive Waste Management

GF456

2101 Constitution Ave.

Washington, DC 20418

Rodney C. Ewing

Department of Geology

University of New Mexico

Albuquerque, NM 87131

Charles Fairhurst

Department of Civil and Mineral Engineering

University of Minnesota

500 Pillsbury Dr. SE

Minneapolis, MN 55455-0220
B. John Garrick

PLG Incorporated

4590 MacArthur Blvd., Suite 400

Newport Beach, CA 92660-2027

Leonard F. Konikow

US Geological Survey

431 National Center

Reston, VA 22092

Carl A. Anderson, Director

Board of Radioactive Waste Management

National Research Council

HA 456

2101 Constitution Ave. NW

Washington, DC 20418

Christopher G. Whipple

ICF Kaiser Engineers

1800 Harrison St., 7th Floor

Oakland, CA 94612-3430

John O. Blomeke

720 Clubhouse Way

Knoxville, TN 37909

Sue B. Clark

University of Georgia

Savannah River Ecology Lab

P.O. Drawer E

Aiken, SC 29802

Konrad B. Krauskopf

Department of Geology

Stanford University

Stanford, CA 94305-2115

Della Roy

Pennsylvania State University

217 Materials Research Lab

Hastings Road

University Park, PA 16802

David A. Waite

$\mathrm{CH}_{2} \mathrm{M}$ Hill

P.O. Box 91500

Bellevue, WA 98009-2050

Thomas A. Zordon

Zordan Associates, lnc.

3807 Edinburg Drive

Murrysville, PA 15668 
Universities

Florida State University ( 8 )

Department of Chemistry

Attn: Dr. Gregory R. Choppin

Tallahassee, FL 32306-3006

University of New Mexico

Geology Department

Attn: Library

141 Northrop Hall

Albuquerque, NM 87131

University of Washington

College of Ocean \& Fishery Sciences

Attn: G. R. Heath

583 Henderson Hall, HN-15

Seattle, WA 98195

\section{Libraries}

Thomas Brannigan Library

Attn: D. Dresp

$106 \mathrm{~W}$. Hadley St.

Las Cruces, NM 88001

Government Publications Department

Zimmerman Library

University of New Mexico

Albuquerque, NM 87131

New Mexico Junior College

Pannell Library

Attn: R. Hill

Lovington Highway

Hobbs, NM 88240

New Mexico State Library

Attn: N. McCallan

325 Don Gaspar

Santa Fe, NM 87503

New Mexico Tech

Martin Speere Memorial Library

Campus Street

Socorro, NM 87810

WIPP Public Reading Room

Carlsbad Public Library

$101 \mathrm{~S}$. Halagueno St.

Carlsbad, NM 88220

\section{Foreign Addresses}

Institute of Analytical Chemistry

University of Vienna

Attn: Prof. Dr. Johann Korkisch

A-1090 Vienna, Wahringerstrasse 38

AUSTRIA

Studiecentrum Voor Kernenergie

Centre d'Energie Nucleaire

Attn: A. Bonne

SCK/CEN Boeretang 200

B-2400 Mol, BELGIUM

Atomic Energy of Canada, Ltd.

Whiteshell Laboratories

Attn: B. Goodwin

Pinawa, Manitoba, CANADA R0E ILO

Francois Chenevier (2)

ANDRA

Route de Panorama Robert Schumann

B. P. 38

92266 Fontenay-aux-Roses, Cedex

FRANCE

Jean-Pierre Oliver

OECD Nuclear Energy Agency

Div. of Radiation Protection \& Waste Mgmt.

38 Boulevard Suchet

75016 Paris, FRANCE

Claude Sombret

Centre d'Etudes Nucleaires de la Vallee Rhone

CEN/VALRHO

S.D.H.A. B.P. 171

30205 Bagnols-Sur-Ceze, FRANCE

Commissariat a L'Energie Atomique

Attn: D. Alexandre

Centre d'Etudes de Cadarache

13108 Saint Paul Lez Durance Cedex

FRANCE

Bundesanstalt fur Geowissenschaften und

Rohstoffe

Attn: M. Langer

Postfach 510153

D-30631 Hannover, GERMANY

Bundesministerium fur Forschung und

Technologie

Postfach 200706

5300 Bonn 2, GERMANY 
Forschungszentrum Rossendorf FZR (2) Institut fur Radiochemie Attn: Der Direktor: Prof. Dr. Heino Nitsche Postfach 510119

D-01314 Dresden, GERMANY

Institut fur Tieflagerung

Attn: K. Kuhn

Theodor-Heuss-Strasse 4

D-3300 Braunschweig, GERMANY

Gesellschaft fur Anlagen und Reaktorsicherheit (GRS)

Attn: B. Baltes

Schwertnergasse 1

D-50667 Cologne, GERMANY

Physikalisch-Technische Bundesanstalt

Attn: P. Brenneke

Postfach 3345

D-3300 Braunschweig, GERMANY

Shingo Tashiro

Japan Atomic Energy Research Institute

Tokai-Mura, Ibaraki-Ken, 319-11

JAPAN

Netherlands Energy Research Foundation ECN

Attn: L. H. Vons

3 Westerduinweg

P.O. Box 1

1755 ZG Petten

THE NETHERLANDS

Svensk Karnbransleforsorjning AB

Attn: F. Karlsson

Project KBS (Karnbranslesakerhet)

Box 5864

S-102 48 Stockholm

SWEDEN

Nationale Genossenschaft fur die Lagerung

Radioaktiver Abfalle (2)

Attn: S. Vomvoris

P. Zuidema

Hardstrasse 73

CH-5430 Wettingen

SWITZERLAND
AEA Technology

Attn: J. H. Rees

D5W/29 Culham Laboratory

Abington, Oxfordshire OX14 3DB

UNITED KINGDOM

AEA Technology

Attn: W. R. Rodwell

044/A31 Winfrith Technical Centre

Dorchester, Dorset DT2 8DH

UNITED KINGDOM

AEA Technology

Attn: J. E. Tinson

B4244 Harwell Laboratory

Didcot, Oxfordshire OX11 ORA

UNITED KINGDOM

D. R. Knowles

British Nuclear Fuels, plc

Risley, Warrington, Cheshire WA3 6AS

1002607 UNITED KINGDOM

\section{Internal}

$\begin{array}{lll}\frac{\text { MS }}{1320} & \frac{\text { Org. }}{6748} & \text { C. F. Novak (10) } \\ 0827 & 1502 & \text { P. J. Hommert } \\ 1324 & 6115 & \text { P. B. Davies } \\ 1320 & 6719 & \text { E. J. Nowak } \\ 1332 & 6121 & \text { J. R. Tillerson } \\ 1395 & 6700 & \text { P. Brewer } \\ 1335 & 6705 & \text { M. Chu } \\ 1395 & 6707 & \text { M. Marietta } \\ 1335 & 6000 & \text { W. Weart } \\ 1395 & 6701 & \text { L. Shephard } \\ 1341 & 6706 & \text { A. L. Stevens } \\ 1328 & 6749 & \text { D. R. Anderson } \\ 1395 & 6743 & \text { V. H. Slaboszewicz } \\ 1341 & 6747 & \text { D. R. Schafer } \\ 1341 & 6748 & \text { J. T. Holmes } \\ 1328 & 6741 & \text { H. N. Jow } \\ 1330 & 6352 & \text { C. B. Michaels (2) } \\ 1330 & 6352 & \text { NWM Library (20) } \\ 9018 & 8523-2 & \text { Central Technical Files } \\ 0899 & 13414 & \text { Technical Library (5) } \\ 0619 & 12615 & \text { Print Media } \\ 0100 & 7613-2 & \text { Document Processing (2) } \\ & & \text { for DOE/OSTI }\end{array}$

